

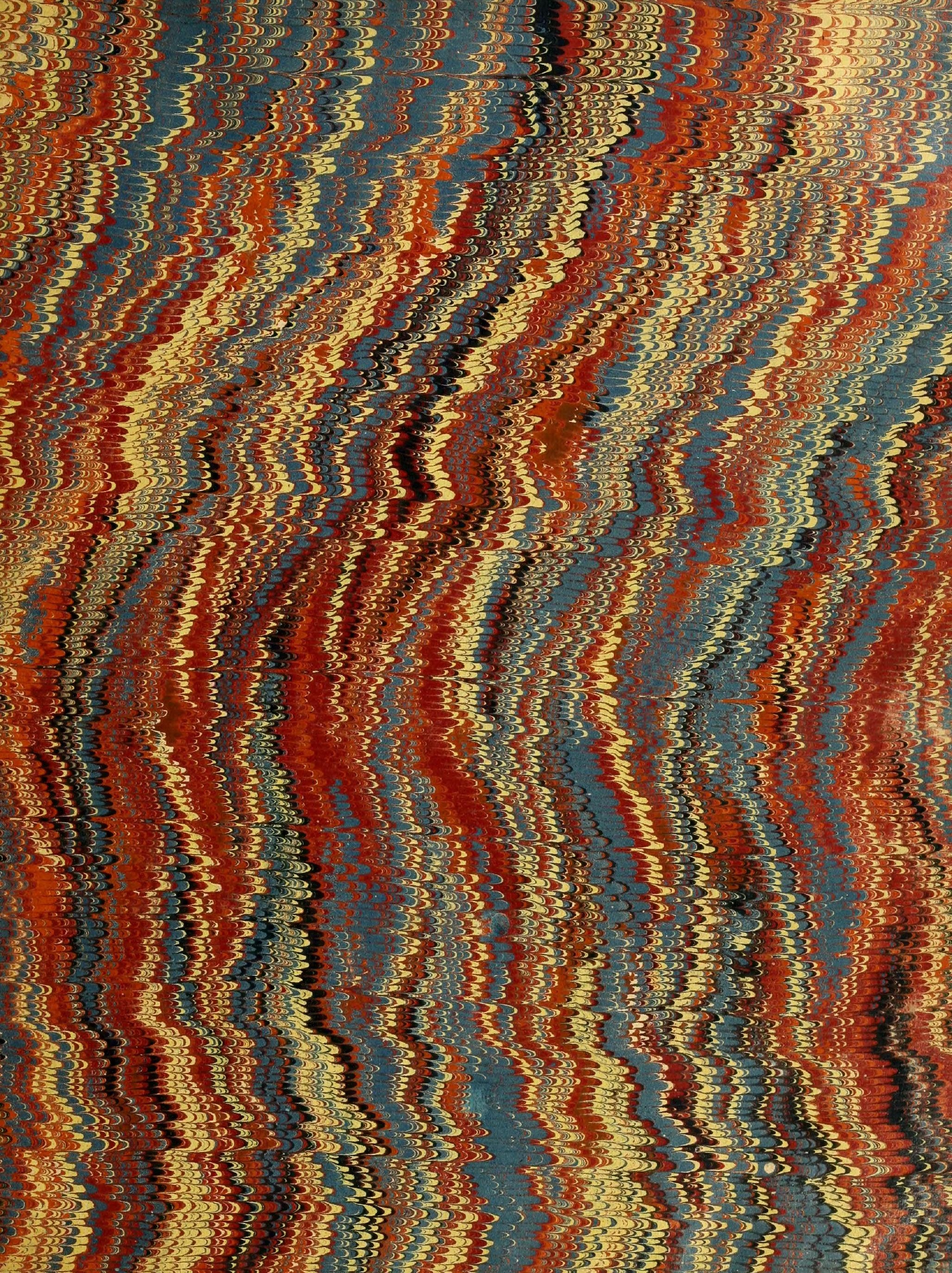





<smiles>[C-]1C=C[CH-]1</smiles> 



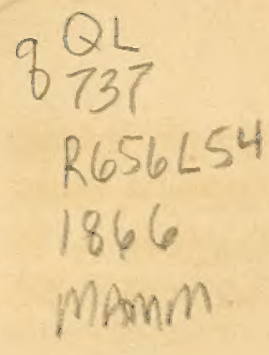

SYSTEMATISK ÖFVERSIGT

AF

DE GNAGANDE DÄGGDJUREN, GLIRES.

AF

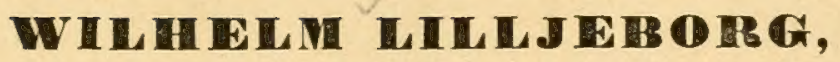

ZOOLOGIX PROFESSOR.

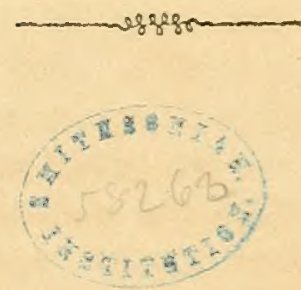

UPPSALA,

Kongt. AKAD. BOCKTRYKutuet.

1866. 



\section{SYSTEMATISK ÖFVERSIGT AF DE GNAGANDE DÄGGDJUREN, GLires.}

I.

Det retenskapliga intresse, som fäster sig vid de gnagande däggdjurens ordning, är frammanadt af tlera omständigheter. Den mangfald och rikedom pá former, som demma ordning företer, är större än inom nagon annan diiggdjursordning. Af de omkring 2300 kïnda arterna af lefrande däggdjur, utgöra gnagarne nära en tredjedel, eller omkring 700 arter. De, som i artantal komma dem närmast, aro de handvingade (Chiroptera) med omkring 500 arter, rofdjuren (Ferae) - med uteslutande af Insectivora - med omkring 250 arter, apdjuren (Quadrumana) och de partiade digggdjuren (Artiodactyla), de förra med nágot öfver 200, och de sednare med omkring 200 arter. Dema formrikedom berisas äfven deraf att slägten förefinnas, som omfatta ett stort antal arter, och der man har svårt för att finna några bestamda formkarakterer, pa grund af hvilka de kunna afdelas i flera generiska grupper. Exempel derpa lemna oss slägtena Mus, Hesperomys och Sciums, det första med öfver 100, det 2:dra med nära 100 och det 3:dje med 90-100 arter; det första tillhörande den Gamla, det 2:dra den Nya Verlden, och det 3:dje alla verldsdelar, med undantag af Australien.

De utmärka sig äfren genom en ridsträckt geografisk uthredning, och cn deI derjemte genom en stor härdighet. Gnagare förekomma i alla verldsdelar och i nästan alla trakter af jorden, sáväl i de varma som i de tempererade och kalla zonerna, saiväl i aquatorial-som polartrakterna, i skogar och pa öppna fült och öknar, i djupa dalar och pa de lö̈gșa berg ända till gramnskapet af den ständiga snön. Sâsom exempel pai deras härdighet ma anföras, att vâra vanliga husrattor, saiväl den stora som den lilla, hvilka ofrivilligt blifiit ïfrerflyttade till näistan alla trakter af jorden, kmma trotsa alla de svirigheter, hrarmed en steril och hàrd natur och oafbrutna törföljelser af memiskor och djur hota deras existens. DARWIs fann pí Üstra Falklands-Ön bicla artema, t. o. m. pa smärre klippöar, lingt skilda fran menniskor's boningar, och på höjden af en liten stenig och torr ö rid Caprerds-öarne tog han ett par exemplar af den lilla husrattan. Att de kumbat uthäda den kalla och fuktiga temperaturen pit Falklands-ïarne, föramar dock mindre, än att de moler en tropiskt brimnande sol kumat lefra på den sterila ön rid Capverds-öarne, der de endast under den korta regutiden fätt smaka färskt vatten, och hrarest icke fumos nígra sucenlenta vïixter. De flesta vilda dïggdjur gaz sin undergang till mötes i samma man som ländernas tillagande folkmängd och sti- 
gande odling rubbar naturens jemnvigt och tillintetgör vilddjurens herravälde; men gnagarne förete flera exempel pai förmiga att besegra de svairighteter, som den stigande kulturen sätter i vägen för deras existens, ja t. 0 . m. att kunua göra sig dem tillgodo, och derföre se vi icke sällan, att de uppträda siisom ett svairt gissel i vistlus, spannmalsmagasiner, trädgårdar och åkrar.

Öfver gnagarnes klassifikation har redan så mycket blifvit skrifvet, att det synes, som detta ämne skulle vara uttümdt; men den stora rikedomen på former inom denna đjurgrupp, och den vexling, som de inre karaktererna ofta förete, under det att öferensstämmelsen i den yttre formen ä missledande, har gjort denna klassifikation till en af de svarare inom denna djurklass, och har hos oss föranledt den öfvertygelsen, att hvarje nytt bidrag till detta ämne, äfen om det icke innebär någon genomgripande reform af de föregaiende, für retenskapen kan vara af intresse. De manga exempel pá den yttre formöfverensstaimmelsens bedrigliglet, som demna djurordning företer, visa nogsamt, huru nödvandigt det är, att vid dess klassifikation anlita imre, anatomiska karakterer, och da äfven dessa, inskränkta till nígot visst organ, stundom kunna vara missledande, kuma vi lätt inse, att det är nödigt att hemta dem frin hvilken kroppsilel det vara mỉ. Bland de anatomiska karakterema äro de, som hemtas frîn skelettbyggnaden, utan tvifyel de bïsta, likväl icke som om de skulle rara säkrare än alla andra, utan derföre att de pâ samma gâng äro bide säkra och lätt tillgängliga. Vi vilja derföre företridlesvis taga dessa i betraktande vid karakteristiken af de större grupperna.

De, som lemnat de bästa bidragen till detta ämne, G. R. WATERIouse ${ }^{1}$ ), J. A. WAGNER $^{2}$ ) och J. $\mathrm{H}^{1} \cdot$ BRANDT $^{3}$ ), hafiva nogsamt insett, att osteologiska karakterer äro af största vigt för dessa djurs klassifikation, emedan dessa författare nästan uteslutande grundat uppstailnningen af de störe grupperna pả dylika karakterer - vi räikna äfren de frân tänderna hemtade till dessa. Men de hafva dock nästan endast hallit sig till benluufvulets eller cranicts byggnad, och churu demna onckligen är bland de allra vigtigaste för berlümandet af frändskaperna, är den dock icke sâ vigtig, att den gör afseendet a de öfriga delarne af skelettet öfverflödigt.

Ehuru de trenne nämnda författarnes systemer öfver gnagarnes ordning för de flesta torde vara bekanta, anse vi oss dock häi i största korthet böra referera dem, för att deri-

1) "Observations on the Rodentia, with a view to point out the groups, as indicated by the structure of the crania in this order of Mammals": Charlesworths Magaz. of natur. History 1839, p. 90, 184, 274 etc. - Tabular view of the distribution of the Rodentia: Proceedings of the Zoological Socicty of London, Part VII, 1839, pag. 172. - Observations on the Rodentia: Annals and Magazine of Natural History, vol. VIII, 1842, pag. 81; vol. X, pag. 197 \& 34. - Natural History of the Mammalia, vol. II, Rodentia or Gnawing Mammalia, London, 1818.

") Gruppirung der Gattungen der Nager in natiirlichen Fanilien, nebst Beschreibung einiger neuen Gattungen und Arten: Archiv für Naturgeschichte von D:r W. F. Erichson, 7 Jahrg. 1 Bd. 1841, pag. 111. - Die Säugthicre etc. von Schreber, Supplementhand, 3:te und 4:te Abtheilung, 1843 \& 1844.

$\left.{ }^{3}\right)$ Untersuchungen tiber die Craniologiseben Entwickelungsstufen und die daron herzuleitenden Verwandtsehaften und Classificationen der Nager der Jetztwelt, mit besonderer Beziehung auf die Gattung Castor: Mémoires des sciences mathématiques, physiques et naturelles, Tome VII, 1854, besonders abgedruckt. 
genom lemna våra läsare tillfülle att anställa en omedelbar jemförelse mellan dem och den systematiska uppställning; som vi sjelfva meddela.

WATERHOUSE indelade gnagame pai följande sätt:

$$
\begin{aligned}
& \text { Familjer: }
\end{aligned}
$$

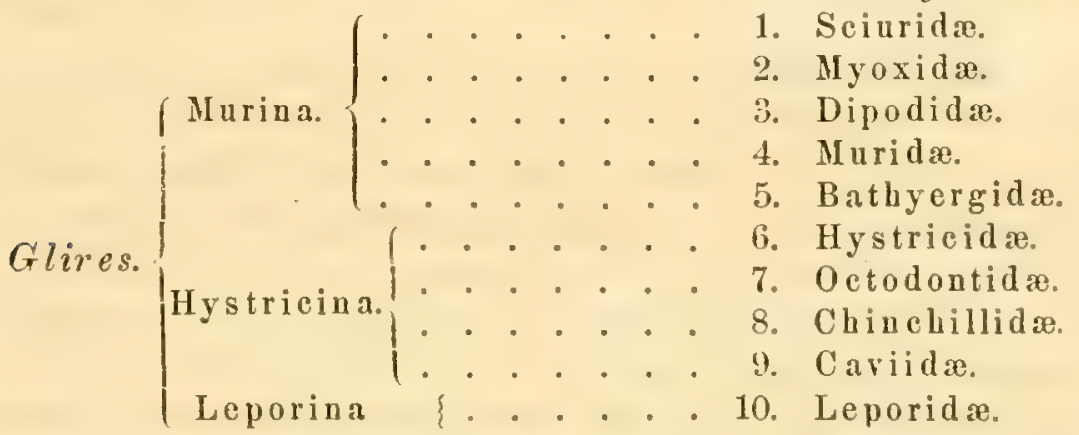

WAGNer uppstallde följande 12 familjer, och förklarade, att den 8:de, eller Murina betraktades af honom sissom en centralpunkt för dem alla. 1. Pedimana (Chiromys); 2. Sciurina; 3. Myoxina; 4. Macropoda; 5. Chinchillina; 6. Psammoryctina; 7. Cunicularia; 8. Murina; 9. Castorina; 10. Hystricina; 11. Subungulata: 12. Duplicidentata. För den 4:de familjen gaf han sedermera (Schrebers Säugthiere) namnet Dipoda.

BRANDT, som med största grumdlighet afhandlat detta ämne, uppställde äfvenledes 12 familjer, jemte underfamiljer på följande sått:

Subordines: Familix: Subfamilix:

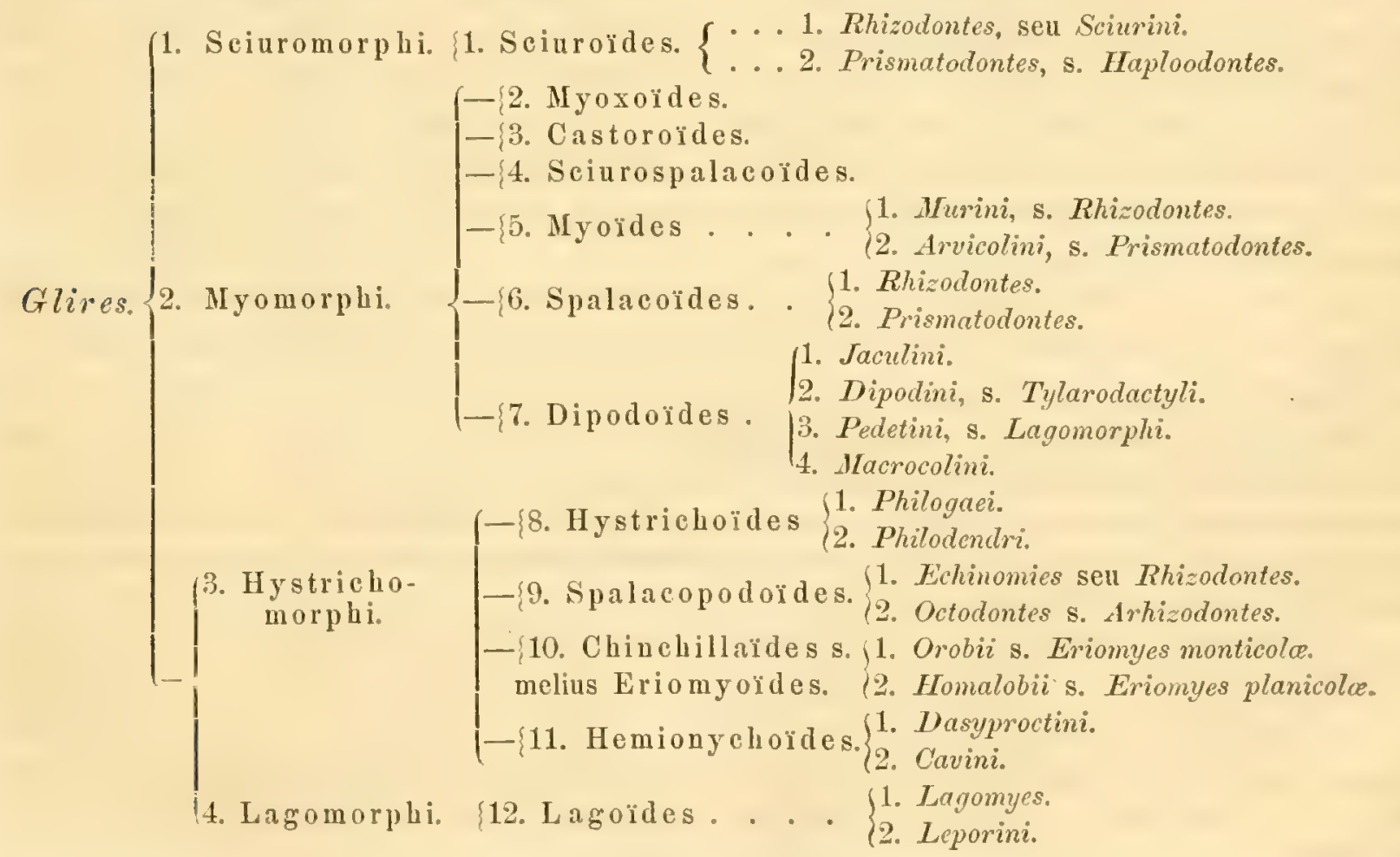


Gnagarne utgöra en serdeles naturlig och väl begränsad ordning, och man är numera icke i villrådighet rörande bestämningen af någon dithörande form. Den, som sednast fürskaffut systematici nagot bryderi i detta afseende, är Chivomys madagascariensis, hvilken, enligt hval vi ofvan sett, änu af WAGNer fördes till gnagarne, och utgjorde bland dem den första familjen Pedimana. Det har likväl redan af Blainvilue (Ostéographie), och sedermera af OWEN ${ }^{1}$, och nu sist af PÉTERS ${ }^{3}$ ) blifvit till fullo adagalagdt, att den icke bör hafva sin plats bland gnagane, utan bland halfaporna. Dess framtänder äro till form, antal och liige fullkomligt lika gnagarnes, med emaljbetïckning endast pả främre sidan, med öppen rot och persistent pulpa, liksom hos dem, och sannolikt ïfen utan ömsning, men den har, enligt PÉters, i öfverkäken bakom dessa ett par helt sma och affallande fiantänter, samt i samma käk äfven ett par affallande hörntänder. Sådana affallande fram- och hörnłänder förekomma icke hos gnagarne. De öfe framtänder, som hos fam. Leporide äro underkastade fälning, efterträdas af de bakre permanenta framtänderna, och hörntänder saknas, sisom bekant, helt och hallet. Emellertid företer dock Chiromys sî mycken öfrerensstämmelse med gnagarne i ansecnde till tänder och cranium, att man svarligen torde kunna finna nágon annan för denna ordning främmande form, som visar en sâ stark tendens till öfvergảng till densamma, och den lemnar oss ett högst anmärkningsviirdt exempel pai, huruledes byggnaden af extremiteterna kan vara af större vight för bedömandet af den naturliga främdskapen, än byggnaden af craniet och tiunderna. Dock fîr det anmärkas, att de öferensstïmmelser med gnagarne, som dess cranium företer, äro framkallade af gnagtündermas närvaro, och att cranict för öfrigt, såsom BLAINTLLE anmärkt, visar flera öfverensstämmelser med halfaporna.

Den för gnagarne mest utmärkande karakteren ligger uttryckt $\mathrm{i}$ deras namn, och vi hafva följaktligen att söka den i deras tandhyggnad; men denna ïr icke endast utmärkande genom sin form och funktion, utan äfven genom sin utveckling. Alla andra däggrljur, som äro försedda med tänder, med undantag af tandhvalarne och Bruta, cnligt Owen ${ }^{3}$ ), vexla tänder, och hafva en affallande eller mjölktandsilentition, uti hrilken hos dem, som hafva tre slag af permanenta tänder (frantänder, hörntänder och kindtänder), alla tre slagen ingai; men enligt G. Cuvier's, Rocsseau's och Owex's iakttagelser underga större delen af gnagarne, nemligen alla de, som hafra tra framtänder i öfre käken, och derjente tre eller färe kindtänder på hrardera sidan i öfre och undre käken, ingen tandömsning; och hos alla äro de egentliga gnagtänderna icke underkastade nigon fälning, emedan det hos Leporide blott är de buda bakre frantänderna i öferkäken som fällas. När kinttandernas antal a hvardera sidan i offe eller undre kiaken öfverstiger tre, äro de, som sitta framom den 3:dje kindtanden, räknade bakifrain, dentes promolares. Genom att på samma ging taga i betraktande framtändernas antal, form och utreekling i förening med hörntindernas franvaro och den egendomliga ntreeklingen af kindtänderna bör man derföre med säkerhet kumna bestämma en gnagare sásom sadan. De som hafia framtänder mest liknande gnagarnes, nemligen Chiromys och

1) Transactions of the Zoological Society, vol. V.

$\left.{ }^{2}\right)$ Monatsberichte der Künigl. Preuss. Akad. der Wissensch. zu Berlin aus dem Jahr 186t, (tr. 1865), pag. 243.

3) Odontography, pag. 307. Dock hafva vi hos en Dasypus fumnit en 2:dra dentition. 
Phascolomys, skiljas derföre: den förra derigenom att den of van bakom gnagtänderna har affallande framtänder, som icke eftertridas af permanenta saddana, samt derjemte affallande hörntänder i öfverkäken; och den sednare derigenom att den vexlar framtänder i öfre och undre käken. En dylik vexling äro äfen framtänderna hos Hyrax underkastade, äfvensom snabeldjurens stöttänder, de tvai mellersta framtändema i underkäken hos flipropotamus, och framtänderna i öfverkäken hos hanen af Halicore, hvilka eljest genom sin persistenta pulpa och följaktligen fortgâende tillväxt öfverensstämma med gnagarnes, om än deras form och funktion är en anman.

Framtänderna hos Toxodon hafva varit mycket lika dem hos gnagarne, och med undantag af de 2 mellersta i öfverkïken, hafva de haft persistent pulpa, och emaljbetäckning endast pa sin främre sida; men deras antal har varit olika, nemligen 4 ofvan och 6 nedan, och de 2 mellersta ofvan hafva rarit mindre än de yttre, och sannolikt affallande, och de i underkäken hafva laft en prismatisk form, hvilken samnolikt äfven tillkommit de i üfverkäken.

Den starka utvecklingen af gnagtänderna och deras funktion är förbunden med vissa egendomligheter i benhufvudets bygguad, bland hvilka vi vilja nämna mellankïksbenens betydliga storlek, underkakens form, och, hvad demna betraffar, isynnerhet den mer eller mindre longitudinella formen af underkïkens ledknappar. Mellankäksbenen räcka med sin bakre och öfe del till pannbenet, och skilja de i allmänhet stora näsbenen fullkomligt fran öfverkäksbenen. Ehuru denua karakter skiljer gnagarne frun de flesta andra diiggdjur, är den dock icke en uteslutande tillhörighet för lem. Vi träfli, waisom BLAIxylle aumärker, samma förhillande t. ex. hos Elephas, Chiromys, Tarsius, Haticore, Rhytina, Manatus och stundom Ursus, Procyon och Hycona, likräl hos de 3:ne sistnämnda slägtena icke derföre att mellankäksbenen hafra fät en serdeles stark utveckling, utan derforre att pambenet utsänder framåt å hvardera sidan en ling spetsig process, mellan öfverkiaksbenen och näisbenen.

Vi vilja icke lär ingå i någon närmare redogörelse för gnagarnes allmänna karakterer, emedan dessa redan förut si många gånger blifvit afhandlade, att dervid icke finnes nagot vidare att tillägga, och vi öfverga derföre nu till vart egentligen föresatta ämme, deras systematiska indelning.

Med hänsyn till frantänderna, som uti gnagarnes karakteristik lemna det vightigaste momentet, finna vi trenne olika grupper; den ena, som omfattar det vida största antalet af gnagarne, med 2:ne framtïnder i öfverkäken, och den andra med 4 sådana. Då dessa grupper icke endast uti de öfre framtäindernas antal skilja sigg från hrarandra, utan äfven förete andra vigtiga skiljaktigheter, anse vi, att de böra betraktas salsom tveme underordningar, och vi gifva at den förra namnet Simplicidentuti, till motsaitninge mot namnet Duplicelentati, lovilket redan af ILLIGER och WAGNER blifvit gifret àt den sednare gruppen, och desto hellre för dema ma bihehallas, som det är serelele; limpligt och grumdadt pa deras mest utmirkaude karakter.

För grupperingen af den första stora underordningen, Glives Simplicidentati, har man hittills för de större grupperna hufvulsakligen endast anlitat kännemärken, sum blifvit hemtade frain benhufundets olika former. Sa har t. ex. BRANDT karakteriserat 1:sta gruppen, 
Sciuromorphi, genom de breda med processus postorbitales försedda pambenen, och de enkla, eller icke af foramina infraorbitalia genombrutna och delade processus zygomatici i öferkiaken ete; 2:dra gruppen Wyomoryh, genom de framtill smala och processus postorbitales saknande pannbenen, genom de af de merendels upptill bredare, och nedtill en smal springa bildande, foramina infraorbitalia dclade processus zygomatici ä öferkikien, oeh genom den frin unlerkiikens undre och icke yttre sida utgaiende angularprocessen ete.; 3:dje gruppen, Hystrichomorphi, genom de mycket stora, triangulara eller njurformiga, och nedtill merendels mycket bredare foramina infraorbitalia, som dela öferkäkens processus zygomatici i 2:ne grenar, af hvilka den undre aldrig har formen af en störe perpendiculiur skifra; genom de breda pambenen och genom den merendels frin underkäkens yttre sida utgatende angularprocessen ete. Den 4:de gruppen, Lagomorphi, som sammanfaller med den här upptagna 2:tlra underordningen, karakteriseras af honom genom de 4 öfe framtänderna; genom de föga utbildade och med enkel rot fursedda processus zygomatici â öfrerkïken; genom de sma foramina infiaorbitalia; genom den en nästan fyrkantig transversell bro bildande palatum ossemm; genom de till ett förenade bath foramina optica; och genom den höga uppstigande grenen ä underkäken, sant genum de en liten böjd spets á densamma bildande anguli, hvilka utgai frain hela dess undre kant, och genom de â densamma varande sma processus coronoidei, som äro aflägsne frän processus condyloidei, etc. Vi vilja ingalumla underkinma vigten af dessa karakterer, och skola derfüre äfven anvïnda dem vid den karakteristik öfrer familjerna, som vi lemua; men ri anse dock, att de blifva fördelaktigare für den naturliga grupperingen och begränsningen af dessa, di de subsumeras under eller tillämpas jemte andra karakterer, hemtade från det öfriga skelettet och från tänderna. Underbenet (crus) synes oss, med afseende pi förhaillandet mellan de bada ben - skenbenet (tibia) och radbenet (fibulu) - hvaraf det består, och dessas form och utveckling, lemna karakterer, som för familjermas grupyering äro af större vigt än te näimnda, och som med större säkerhet och lätthet limna tillämpas, emedan de förra stundom äro underkastale betydande modifieationer och icke sá fà undantag. Saledes fimna vi t. ex. hos springrattorna (Dipodide) en eranieform, som, hvad de ofvan anförda karaktererna beträffiur, i det närmaste öferensstämmer med de Iystrichomorpha gnagarnes, ehuru de patagligen höra till de Myomorpha, och derföre med rätta af BrAND'T räknas till dessa sednare. Inom Spalacidernas fanilj trïffa vi en betyellig föränderlighet uti cranieformen, sai att man vid ett uteslutande afsecnde pa denna form skulle fimn sig föranlaten att afilela denua naturliga familj atminstone uti treme fimiljer. Af demua sednare asigt var derföre WAterhouse, da han uli Amuals and Magazine of Natural History, vol. VIII, für 1841, uppstillde familjen Bathycryider, onfattande endast slägtena Bathyergus och Georyehus. $\mathrm{Vi}$ skulle derföre vilja tro, att BRANDT, da han uppstailde familjen Spulacoüles, füreträidesvis fästat sig vid de yttre karakterer, som af honom först anföras. Äfven må det anmärkas, att man vid ett ensidigt afseente a cranieformen hos de Sciuromorpha gnagarne kommer att betrakta dessa sisom en afskild gruple gent emot alla de andra Simplicidentaterna, och dervid med serskildt afsecude pai det aplika uti en del dithörande formers byggnad och rörelser gerna ställer dem i spetsen für alla gnagarne, churu den betydliga bredden af deras pannben samt byggnaden af underbenet (crus), enlight var uppfattning, tydligen visa, att de böra hafva sin plats mellan de Myomorpha och de Hystrichomorpha gnagarne. 
Vi hafva sagt, att underbenets båda ben (tibia och fibula) hos fullt utbildade och äldre djur lemna vigtiga karakterer för grupperingen af Glires simplicidentati. Dessa ben förete hufudsakligen trenne skiljaktiga formel. Den ena af dem är den, der fibula är ofulständig derigenom att den nedtill ï sammansmält med tibia, sai att gränsen mellan dessa bida ben der har försvunnit. OWEN uplghifer ${ }^{1}$ ), at en transversell genomskärning af dem hos Bäfvern risar, att deras tïta väggar fullständigt sammansmält med hvarandra. Till denna formen hörer äfven att hafva den öfre ändan af tibia starkt böjd framåt, så att der blir en stor öppning mellan de båda benen, der de äro skilda. Denna form af underbenet tillhör alla de Myomorpha gnagarue, och den torde erbjuda den bästa allmänna karakter genom hvilken denna grupp kan skiljas frín de bida andra grupperna af Simplicidentaterna. Der fimes visserligen ett eller annat undantag, men dessa äro högst fà. Det händel någon gång att hos dem, som hafva fullständig fibula, skild frän tibia, dessa ben doek nedtill sammanväxa, men man kan di $\mathrm{i}$ allmänhet liatt spåra gränsen dem emellan. Exempel derpå lemuar en eller annan art af slägtet Sciuroptems. $\AA$ den andra sidan hafva vi bland dem med nedtill sammansmailta nnterben nigon ging en form, der fihula visar sig starkare utbildad och kau temligen tylligt sparas till hela sin längd, och bibehaller sig länge skild fran tibia. Exem-

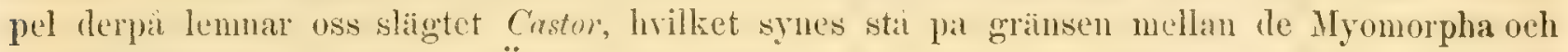
de Sciuromorpha guagarne. Äfren hos Cricetus frumentrems är fibula serdeles stor och starkt

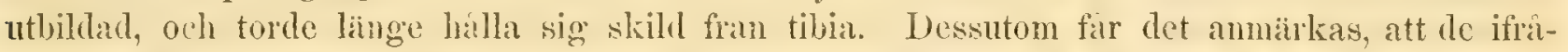
gavarande benen äro fullstandigt skilda hos helt unga individer af sudtana arter, som sedermera hafva dem nedtill sammansmälta. Hos Dipodiderna är fibula serdeles liten, och hos slägtet Dipus iir den sammansmält med tibia under större delen af dess längd; men man kan dock finna spår till dess nedre ända, eller malleolus, ehưu äfven denna icke är fri.

Den andra formen, som tillkommer bade de Sciuromorpha och de Hystrichomorpha guagarne, är den, der fibula stäudigt äl skild frin tibia, och saledes är fullständig. Demna byggnad af fibula är $\mathrm{i}$ almänhet förenad med en mera rät form af tibia, si att denna upptill är föga eller icke böjd, och öppningen mellan dessa båda ben är smal. Detta är isynnerhet fürhallandet hos de Ilystrichomorpha gnagane, och i mindre gud hos de ściuromorpha, hvilka uti formen af tibia visa en tendens till de Myomorpha.

Vi vilja äfven ytha hågra ord om ett annat ben, som isynnerhet hos äldre författare spelat en rigtig rol vid gnagarnes klassifikation. Detta är nyckelbenet, clavicula. G. CuVIER $^{2}$ ) och DESMAREST ${ }^{3}$ ) hafva ansett detta ben så vigtigt för klassifikationen, att de derpå grundat indeluingen af hela ordningen uti 2:ne grupper, den ena ned fullständiga och den andra med rudimentära eller inga nyckelben. Deuna indelning har dock befunnits mindre

1) On the Anatomy of Vertebrates, vol. II, p. 381. - $\AA$ samma stialle, p. 383, uppgifver samme författare, att hos Helcumys (Pcdctes caf̂jer) filuula har den nedersta ändan (mallcolus) afskild frân tibia, ehurn dess nedre tredjedel eljest är sammansmält med denna. Samma fürbållande hafva vi observerat hos yugre individer af Arvicola agrestis, och det förekommer sannolikt ganska ofta äfven hos andra. Vi se således häraf, att fibula har sina båda extremiteter jemfürelsevis mest utbildade.

2) Reurne Animale, 1:re édit. 1817.

3) Mammalogie, 1822. 
lämplig, och man (WAGNER och BRANDT) har med rätta deremot ammärkt, att efter denna indelniugsprincip slägtet Lagomys skulle komma att fî sin plats inom en amnan grupp, än den för slägtet Lepus, ehuru de med hvarandra äro nära beslägtade. Denna anmärkning är fullt befogad; men vi äro dock öfvertygade, att dema karakter med fördel kan användas för begränsningen af ett par mindre grupper. Det är visserligen samnt att detta ben företer flere olika grader uti sin utveckling, să att det hos dem, som hafva det fullständight, d. v. s. fästadt med sin ena inda vid scapula och med den andra vid sternum, stundom är gröfre och stundom spensligare; och af dem, som hafva det ofullstaindigt, d. v. s. icke med sina bâda ändar fustadt vid de nuimnde benen, hafva somlige det helt litet, eller rudimentärt, och andra deremot hafva det temligen stort.

Ämnu en karakter för gnagarnes indelning må serskildt omnämnas. Deuna är kindtändernas byggnad, men icke med hänseende till beskaffenheten af deras kronor, utan med hänsyn till deras rötter. Kronornas sai kallade strecktecknade eller ock knöliga form är underkastad en sådan mängd i hvarandra öfergående rariationer dels pa grund af olika álder och dermed förbunden olika nötning, och dels pa grund af de egendomliga former, som tillhöra olika arter och slägten, att den ej rätt väl duger sasom karakter för begränsningen af större grupper eller familjer. Men deras rötter förete en mera konstant form, och demna lemnar utan trifvel bättre kämnemärken för familjernas underaftehning i underfamiljer. Man har likräl nágon gâng öfverskattat vigten af dessa kämnemärken, och derpà grundat uppstallningen af större grupper. Sil har F. Ccvies ${ }^{1}$ ) indelat gnagame uti 2:ne grupper, af hrilka den ena onfattar suldana, som hafva rötter it kindtanderna, och dessa kallas Rongeurs Omnivores, och den andra omfattar sådana, som sakna dylika rötter, och dessa kallas af honom Rongeurs Frugivores. Att en sådau indelning är högst onaturlig, och att genom den former blifra ryckta i sili, som med hrarandra hafra den nairmaste naturliga frändskap, synes lätt rid betraktaudet af den här nedan följande uppställningen af familjerna.

Den kindtandsform, som är förenad med rötter, är den, der roten tydligen risar sig afskild fran tandens mellersta del, eller collum, och :umu mera fran kronan, och der den är sluten. Ofta är den delad uti 2 eller flera grenar eller serskilda rötter, och en sådan tands tillväxt är begrainsad, emedan den saknar persistent pulpa. Vid mera framskriden alder är den derföre merendels kort, och har starkt afnött krona. En saidan form fimna vi t. ex. hos Mus och Sciurus. Den form, der kindtinderna sakna rötter, ïr den der tändernas basaldel är öppen och olelad, och den air vanligtvis till sin form icke skild fram den mellersta delen, eller collum. Det är isynnerhet dessa tänder, hvars kronor man kallat strecktecknade; och de i kronorna mer eller mindre djupt ingående vecken af emaljen fortgå merendels laings tändernas sidor ända till den öppna basen. En sådan form finna vi to ex. hos Arvicola, Nyodes och Lepus. Oss synes det emellertid, att man icke med fog kan helt och hallet främkiuma sidlana tänder rötter, om än dessa icke :iro utmärkta genom nigon serskild form, samt äro öppna; och vi kalla dem derföre kindtänder med ofullständiga rötter, och benämna deremot de andra kindtänder med fullständiga rötter. Rötterna äro öppna, emedan de hafva persistent pullan, som der har sitt lïge, och deras tillväxt är derföre oaf'bruten, eller fortgar

1) Des dents des Mammifères, Paris 1825, pag. 141. 
Prg. 9.

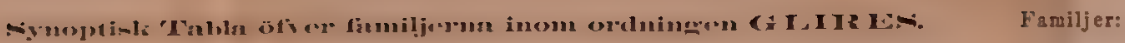

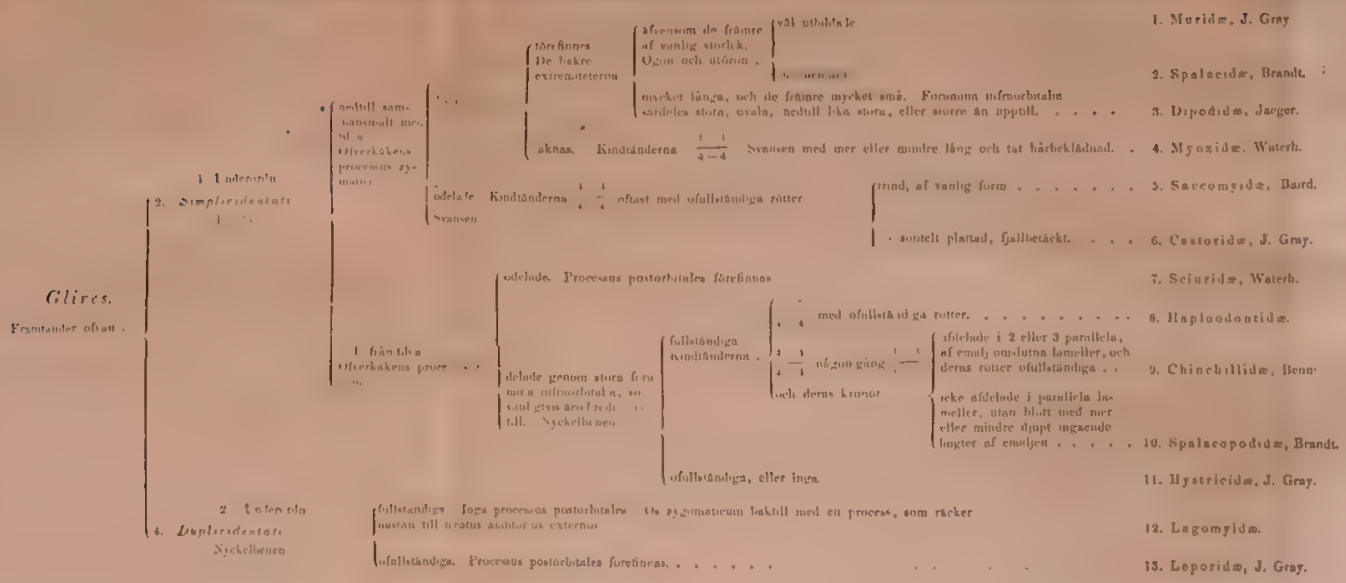


i mån af afnötningen under hela lifvet. Det händer niogon gaing vid högre silder, att rötterna sluta sig, tandpulpan dör bort och tillväxten följaktligen afstannar, men man kan dock alltid genom dessa rötters irreguliära form skilja sådana tänder frân dem, som hafva fullständiga rötter, och denna bildning lemnar derfüre ett i allmänhet ganska godt kïnnemäike för mindre grupper. Sásom öfvergảngsformer má, enligt J. A. WAGNER ${ }^{1}$ ), nämmas slägtena Hystrix och Fiber, samt arten Arvicola glareolus. ILos det förstnämnda slägtet hafva kindtänderna i ungdomen öpna rötter, men fà dem slutna, da de blifvit äldre. Samma förhallande är det med Arvicola glaveolus. IIos Fiber zibethicus äro dessa tänders rötter alltid till formen skilda frán den angränsande delen af tänderua, och cmaljvecken fortsättas icke öfver rötterna, och enligt Wagner äro dessa stundom slutna. Sjelf har jag likväl funnit dem öppna.

П.

Efter dessa inledande anmärkningar rörande nâgra grunder för gnagarnes indelning i större grupper, öfvergá vi till uppstïllningen af dem och dithörande familjer, vch lemma till en början öfver dessa en synoptisk tablå.

\section{1:sta Underordn. SIMPLICIDEN TATI.}

Demna underordnings mest utmärkande karakter är naturligtvis den, att endast lafva 2:ne framtänder i öfverkäken. Für öfrigt företer den en så betydlig mangriald af former, att man har svirt för att fimn nigra andra konstanta karakterer, som skilja den ifran den 2:dra underordningen. \ craniet företer gomhralfvet (palntum osseum) icke formen af nagon bro, och dess längd är alltid myeket större ïn dess bredd mellan kindtandraderna. Foramina optica äro skilde.

I öfverensstämmelse med BRANDT anse vi, att denna underordning kan afdelas $\mathrm{i}$ 3:ne större grupper: 1. Myomorphi, 2. Sciuromoryhi, och 3. IIsstrichomorphi: den fürstuämnde omfattande de sex första familjerna, den andra den 7:de familjen, och den tredje den 8:de till och med 11:te familjerna.

\section{Familjen Muridœ. J. GRAY. (Myoïdes, BRANDT).}

Denna familj omfattar ett större antal arter än någon annan ${ }^{2}$, och synes med skäl kunna betraktas saisom den för hela ordningen mest typiska gruppen. Dess namm tillkïnnagifver, att slägtet Mus är den för densamma typiska slägtformen. Ögonen och utöronen äro i allmänhet viil utbildade, ehuru de sednare stundom äro dolde i hárfïllen. De framre och bakre extremiteterna äro af vanlig storlek. Fötterua, med högst fâ undantag, äro utan sint-

3) Archiv f. Naturgeschichte, 7:er Jahrg., 1841, pag. 112.

2) Öfrer 300 arter hafva blifvit beskrifna. 
hud, framfötterna merendels med 4 fullständiga tår och en rudimentür tumme, och bakfötterna med 5 târ. Sransen är alltid tydlig. $\perp$ craniet är pamman mellan orbita smal och å sidorna mer eller mindre inknipen eller utringad, och saknar processus postorbitales. Öfverkäkens processus zygomatici äro genom foramina infraorbitalia delade uti 2:ne grenar, af hvilka den öfre är mindre och horisontelt plattad, och den nedre har formen af en vertical, hoptryckt skifva. De nämunda foramina, som nästan utan undantag ïro af medelmattig storlek, hafva höjoldimensionen störst, och äro upptill störst samt nedtill helt smala, och lemna der genomgang för infrarbitalnerven, och $\mathrm{i}$ sin öfre bredare del för en gren af musculus temporalis ${ }^{\mathrm{I}}$ ). Öfverkiiken företer vil früme kanten af foramina infrarbitalia i hvardera sidan en mer eller mindre utstiende knöl. Arcus zygomatici äro mer eller mindre starka och utstiende. Underkïkens angularprocess utgàr frän underkäkens undre kant och är triangulär, med spetsen mer cller mindre uppait böjcl. Med undantag af năgra fä arter, iiro kindtiunderna ${ }_{3}^{3}=\frac{3}{3}$, af omvexlande form i ansecude till kronor och rötter. Nyckelbenen äro fullständiga, men vadbenen (fibulce) äro nerltill hos fullt utbildade individer sammansmälta med skenbenen (tibice). Blindtarm förefinnes.

I afseende pî̀ tändernas byggnad företer denna fanilj tvenne skiljaktiga former, pả grund af hvilka den bör afdelas i 2:ne underfamiljer.

\section{Underfam. Murini, Brandt.}

Kindtänderna med fullständiga rötter. Yannan à benhufvulet plattad, med mer eller mindre skarpa sidokanter. Tandraderna korta, och bakre kanten af gombenen merendels belägen bakom de bakersta kindtänderna. Frantiunderna merendels hoptryckta och smala.

\section{Underfam. Arvicolini, BRANDT.}

Käindtänderna med ofullständiga rötter. Pannan à benhufvudet serleles smal, med afrundade och starkt utringade sidokanter. Tandraderna lingre, och bakre kanten af gombenen belägen framom bakre ändan af de bakersta kindtänderna.

För att underlitta öfversiggten af de till dessa underfamiljer hörande slïgten, meddela vi öfrel dem synoptiska tablier. De obetydliga formskillnaler, som fürefimnas mellan en stor del af te till den förra underfamiljen hörande slägtena, hafia stundom gjort det stärt för oss att finna súlana bestämda och skarpa karakterer, som iiro af nöden för deras sjnoptiska uppstailhing. Vi indela dem efter kindtändernas antal uti 3:ne sectioner, sílunda:

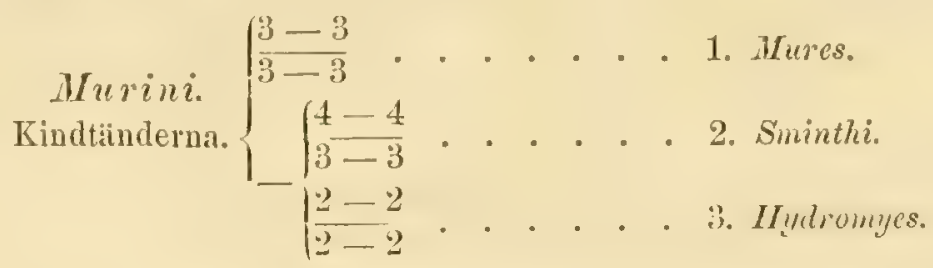

3) Han brukar vanligen uppgifva, att denna muskel är masseter; men dâ den utgâr fri̊n midten af underkäkens corpus, synes det oss antagligare, att den är en gren af temporalmuskeln. 
Af dessa omfattar den 1:sta sectionen nästan alla Murini, och de tvenne sednare eudast nigra fâ arter. Redan 1840 lade WATERHoLsE ${ }^{1}$ ) iakttagit, att de Amerikanska Mures uti kindtändernas byggnad afvika fran dem, som tillhöra den Gamla Verlden, och han uppställde för en stor del af de Amerikanska arterna det nya slïgtet Klesperomys. Detta föranledde sedermera J. A. WAGNER ${ }^{2}$ ) att upptaga dem sasom en serskild grupp, under benämningen

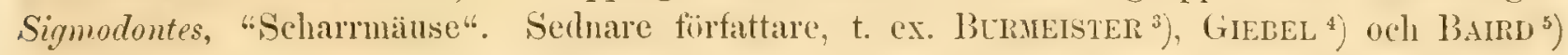
hafva foljt detta exempel, och vi anse oss derföre kuma betrakta denna grupp sisom grundad på en väl konstaterad erfarenhet. Dess utmärkaude kännemärke är detta, att kindtänderna, som äro något mindre, än hos Gamla Verdens Mures moprii, och som i ungdomen hafva knölig krona, liksom dessas, endast hafra trenne knölar i hrarje transversell rad, och således endast tremne långsgaiende rader af-knölar, i den öfre käken likasåäl som i den undre, da kindtandraderna betraktas langsat fran nagondera af deras andpunter. Vid stigande alder oeh dermed förbmenen nötning försvima knibarne, och kronan blir plattad och strecktecknat, eller med sicksackformade alternerande emaljveck. Hos Mnres promii, sasom vi vilja kalla dem från Gamla Verlden, förefinnas treme knölar i hvarje transversell rad å kindtandema i öfverkäken, och saledes treme langsgaende rader af knölatr; och äfen efter nötningen förete knölradema mer eller mindre uppstaende kanter at emaljen. L'nderkäkens kindtander hafva, liksom hos Sigmordontes, endast treme lingsyalende knölrader, men de skilja sig dock frän dem af de sednare derigenom, att deras emaljyeck efter naigon nötning visa sig genomträngande kronau helt och hallet fran ena sidan till den andra, och äro icke sicksackformade sisom hos lessa.

Vi hafva siledes karakteriserat trenne större grupper af Mrures. Ännu en tredje grupp, tillhörande den Gamla Verlden, återstion. Sasom ri sett, hafra de 2:ne nämnda gruppernas kindtäinder i början knölig krona, med 2 eller 3 knölar i hvarje transversell rad. Den 1 m ifragararande gruppen skiljes fran dem derigenom, att kindtänterna redan frin den tidiga ungdomen hafia strecktecknad krona, och de förete härigenom en tendens till Arvicolini. Tillfölje häraf hafra de af BRANLT fătt benämungen Mures merioniformes sen Arvicolini. BAIRD ${ }^{6}$ ) yttrar den fömodan, att de $\mathrm{i}$ sin allra tidigaste ungolom samolikt hafía transversella och nästan parallela ryggar a kindtändernas kronor, men dessa ryggar äro jemma och förete inga knöliga upphöjningar, och da de strax derefter blifva nagot afnötta, fürete de formen af smala transversella och oafbrutna slyngor af emalj, gående trårs öfver tanden, frin ena sidan till den andra. Efter starkare afuötning visa tandkronoma sig försedela med livin tändernas bada sidor djupt inträngande, och intill hrarandra stötande, sant merendels hrarandra motsatta (icke alternerande) reck af emaljen. Dessa tandkronor förcte derföre $\mathrm{i}$ allmänhet ett mera reguliert utseende, än de afnötta tandkronorna af de båda fürsta grupperna. Vi

1) The Zoology of the Voyage of Beagle, Mammalia pag. 74.

$\left.{ }^{2}\right)$ Schreber's Säugthiere, Supplement, 3:te Abtheil., 1843, prg. 509.

$\left.{ }^{3}\right)$ System. Uebers. d. Thiere Brasiliens, 1:ster 'Th. Såugth., p. 156. - 1854.

4) Die Sångethire etc, p. 536. - 1855.

s) Mammals of North America, p. 445. - 1859.

o) L. c. pag. 435 . 
anse oss böra för denna grupp bibehâla den af WAGNER ${ }^{1}$ ) först gifna benämningen Merionides, "Renumäuse". Dessa till sectionen Lures hörande 3:ne grupper, eller tribus, kunna uppställas på följande sätt:

\section{Tribus:}

Mures. (knöliga, i öfver-\{3:ne långsghende rader af knölar. 1. Mures proprii, BRANDT.

Kindtänderna i) käken med. . 22:ue långsgiende rader af knülar. 2. Sigmodontes, WAGNER.

början ... Strecktecknade, eller möjligen med transversella ryggar utan knölar . . . . . . . . 3. Merionides, WAGNer.

\section{Underfam. MURINI.}

Anm. Den här bifogade tablån lemnar en systematisk öfversigt af slägtena inom underfamiljen Murini. Vi vilja dock icke passti, att förteckningen öfver slägtena ür allieles fullstïndig, dả dertill fordras en rikligare tillgång till litteratur, än den, som varit oss medgifven, men vi våga dock hoppas, att de slägten, som för oss förblifvit obekanta, och som böra hafva en egen plats vid sidan af de här upptagna, äro ganska fa, och att denna tablä följaktligen lemnar en temligen fullständig öfversigt af de olika former, som utgöra den ifri̊gararande gruppen. $\AA$ andra sidan vilja vi icke heller pâstâ, att alla här upptagna slägten kunna betraktas såsom säkert grundade i naturen. En del synas hvila pa obetydliga karakterer, och künnedomen om andra är alltför ofullständig, för att medgifra någon full säkerhet uti deras begränsning; men ehuru vi i brist på tillgång till typexemplar icke haft tillfälle till att med behörig kritik bedüma deras värde, hafra vi likväl ansett oss böra upptaga dem, sådana de framställts uti de citerade läroböckerna och beskrifningarne. För att ât de läsare, som icke hafva tillgång till de skrifter, der dessa slägten blifvit beskrifna, om dem lemna något närmare kännedom, än den, som kan inhemtas af den synoptiska tablån, anse vi oss böra meddela en kort redogörelse för dem"2).

\section{Sectionen MURES.}

\section{Tribus Mures proprii, BRANDT.}

\section{Slägtet M us, LiNNÉ.}

Kindtänderna aftaga betydligt i storlek bakăt, så att den bakersta är minst, men den första är dock icke dubbelt större än den andra. Den 1:sta kindtanden har :, den 2:dra har 4, och den 3:dje har 3 skilda rötter. Benhufvudet är temligen smalt, liugsträickt-ovalt, med föga utstacnde och smala okben. Interparietalbenet har den transversella dimensionen störst. IIärällen ä̀ mer eller mindre mjuk. Öronen nästan nakua, stora, uppstiende ur fällen (= $=\frac{1}{3}-\frac{1}{2}$ af liufvudets läugd). Svansen lang, glest härig, med tydliga fjülliga hudringar. Framfötterna med 4 fullständiga târ och en rudimentär tumme, bakfütterna med 5 fullständiga tår, och de bakre extremiteterna längre än de främre. (Mus decumanus, Pallas, \& musculus,

') L. c. pag. 467.

2) Vi förbigí härvid merendels sibdana uti tablin framstailda karakterer, som icke tarfva någon vidare belysning, och sådana, som uti karakteristiken öfver grupperna blifvit afhandlade. 
Pag. 12.

U IRIT.

Slägten:

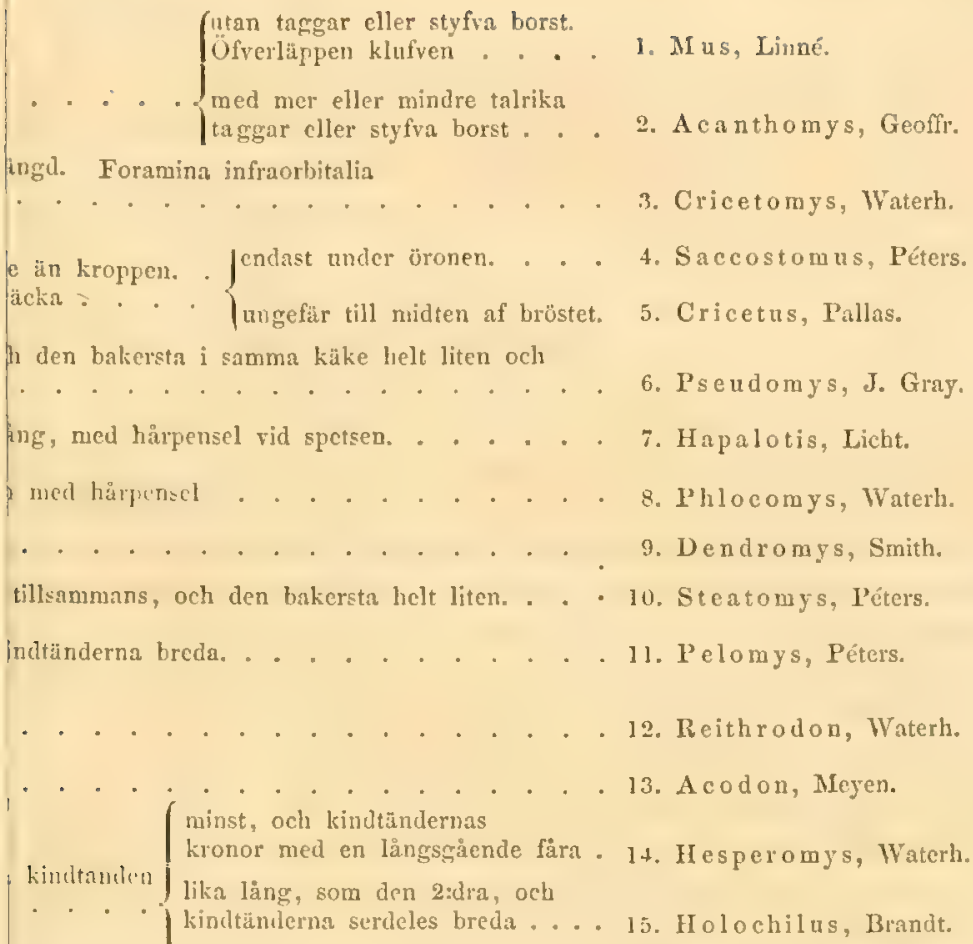





Lin.) 100-120 arter från Europa, Asien, Afrika och Australien. De, som förekomma i Amerika, äro dit importerade 1:

\section{Slägtet Acanthomys, J. GeofFror.}

De ïro till formen föga skiljaktiga frản dem af föregiende slägte, och skiljas derfüre icke generiskt frân dem af WAGNer. Den karakter, pa hvilken man lagt den största vigten, är den, att de pá den öfre kroppssidan hafva mer eller mindre talrika taggar, eller tagglika borst, som hafva en kort spets, och äro plattade samt a öfre sidan försedda med en midtåtgående rïnna. Öron, srans och fötter bildade ungefür pii samma sätt, som hos Mus. Nosen är nìgot längre framstiende framom munnen. Benhufvudet utmärker sig, enligt PETERs ${ }^{2}$ ), derigenom att fossæ pterygoidea aro mycket grunda, och att foramina palatina nästan helt och hållet saknas. - Blott ett ringa antal, omkring 5-6, merendels små arter frion Afrika och Indien (Acanth. cahirinus, Geoffroy).

\section{Slägtet Cricetomys, Waterhouse.}

Enligt Waterfouse ${ }^{3}$ ) och Temmixck ${ }^{4}$ ) utgör detta slägte en mellanform mellan MLs och Cricetus, men företer dock niogra karakterer, hrarigenom det skiljer sig frân bada dessa slägten. Enligt TEmynck har det 2:ne skilda afdehingar af spenar, nemligen 4 pá buken och 4 pi bröstet mellan främre extremiteterna, och de yttre sidotirna stödja på marken och äro endast föga kortare än de 3 mellersta, som äro längst. Stora kindpåsar, liksom hos Cricetus, fürefimas. Benhufvudet är mera lingsträckt in hos Mus, derigenom att det har längre näsben, och kindbaigarne äro mera räta, mindre utbildade och kortare. Foramina infraorbitalia äro nästan runda, och foramina incisiva äro mindre. Underkäkens angularprocess är bredare och mot spetsen något uppstigande. För öfrigt liknar det till kroppens, öronens och svansens form slägtet Mus. - Blott en art af detta slägte är känd ${ }^{5}$, Cr. gambianus, Wateriouse, som är omkring dubbelt störe än Mhs decumamus, med kroppslanglen 16“. Förekommer i mellersta Afrika frân dess vestra till dess östra kust.

') C. J. Sundevall, uti K. Vet.-Akad:s Handl. f. år 1842 (tr. 1843', pag. 219, uppställer en subgenerisk grupp under sl. Mus, som han kallar Isomys, karakteriserad derigenom att de båda yttersta baktårna äro lika långa. Den synes oss icke med fog kunna upphöjas till raug af genus, ehuru benhufvudet utmärker sig genom en kortare och bredare nos och bredare okben. (Isomys variegatus Brants, \& testicularis Sund.).

2) Naturwissensch. Reise nach Mossambique. Zoologie; Säugethiere, p. 161.

3) Annals and Magazine of Natural History 1841, vol. VI, pag. 220.

$\left.{ }^{4}\right)$ Esquisses Zoologiques sur la côte de Guiné, Mammifères, 1853, pag. 165.

5) Wagner, L. c. p. 451, upptager ännu en 2:dra art frin Kanada, Cr. myoides (Gapper), men denne är, enligt BAIRD, en Hesperomys. 


\section{Slägtet Saccostomis, PÉrERS.}

Fnligt PETEns ${ }^{2}$ ) stiu (letta slägte uti benhufvulets och tändernas form närmare slägtet Mus in sl. Cricetus. Frain det förra såval som från sl. Cricetomys skiljer det sig genom sin korta svans, som saknar hudringar och icke är af kroppens halfva längl. Kindtaindernas knölar äro smi. Benhufvudet liknar det af Mus, nen angularprocessen a molerkiken är helt kort och trubbig. Blott 2:ne arter af ringa storlek, fran Mossambique i Afrika. (S. lapidarius, Pet.)

\section{Slägtet Cricetus, Pallas.}

Kroppsformen tjock och undersätsig, med temligen korta extremiteter, och tarna bildade såsom hos Mus. Den korta svansen är temligen tiithårig, utan tydliga hudringar. De inre kindpåsarne äro mycket stora, och räcka till bröstet. Hos Cric. frumentarius, Pallas, äro de 3" linga. Benhufrudet är mindre langstuaickt äl hos de typiska Wures, med kort och fjock nos, ungefïr sásom hos subgen. Isomys, ScxDEYald. Orbitalkanterna a panmenen nagot plattade. — Enligt WAGNER 9 arter från Europa och Asien.

\section{Slägtet Pseudomys, J. GraY.}

Kännedomen om detta slägte är serdeles ofullständig, grundad endast på den korta beskrifningen af I'rof. GRAY ${ }^{2}$ ). Ẍfen de üfre kindtanderna äro aflanga, oeh den fräimsta af dem är störst, och ¿̊ yttre sidan endast försedd med ett emaljveck. Öronen äro temligen stora och nästan nakna. De fräimre och bakre extremiteterna nästan lika långa. Framfötterna med 4 fullständiga tår och en nåstan rudimentär tumme, med klo. 2:dra och 3:dje tån ungefiur lika och längre än 4:de (5:te), som är kortast. Bakfötterna med 5 fullstäncliga tär, af hvilka 2:dra-4:de äro nästan lika, och den 5:te är kortare. Svansen lång och smal samt betäekt af korta hitr. -- En art, Ps. anstrulis, Gr., 5. "lang, med sransen $3 \frac{1}{4} "$, frin Nya Holland.

\section{Slägtet Ha palotis, Lichienstein.}

Euligt WAGNER ${ }^{3}$ ) kämes detta slägte derpå, att underkỉken nästan saknar processus coronoideus. Kindtanderna ofvan hafva ă kronan tvärgående ryggar, som genom en langsgående fâra äro afdelade $\mathrm{i}$ 2:ne afdelningar, och de aftaga i storlek bakàt. Öronen äro serdeles linga, mot spetsen afsmalnande, och tumbariga ${ }^{4}$ ). Fötterna mel 5 tár, men tummen a framfötterna rudinentär, och de mellersta tarna füga lïngre. Metatarserna äro betydlight fürlängda, och de hakre extremiteterna derigenom mycket längre in de framre. Detta gör, att de hafva

1) L. c. p. 166.

$\left.{ }^{2}\right)$ Proceed. of the Zoolog. Society 1832, part. II, p. 39.

3) L. c. p. 457.

${ }^{4}$ ) De langa öronen gifva at hufvudet ett kaninlikt utseende. 
en habitnel likhet med dem af slägtet Dipus, cller snarare Meriones. Sransen är lang och smal, med harpensel vid spetsen. Omkr. 8 arter fran Nya Holland, af livilka den ena, bekant genom de stora rishögar, som den sammandrager till sitt bo ( $H$. albipes, LicHт.), är en och eu half gånger större än vår stora husråtta.

\section{Slägtet Phloe omy s, Waterhouse.}

Den art, på livilken detta slägte är grundadt, lär vara den största inom hela Muridfamiljen. Kroppslänglen är 19" och sransen 13"1). Enligt Waterhotse ${ }^{2}$ ) är dess benhufvud mera oralt ån hos Whs, men dess bakre eller occipitaldel år långstrỉekt och ganska smal. Pamnans bredd är jemförelsevis stor, och bakom orbitre äro pambenen utbredda och bilda der i föreniug med timningbenen tydliga processus postorbitales. Interparietalbenet är nästan cirkelrundt. Bullæe ossæe äro helt smả. De öfre kindtandraderna divergera bakat. Processus coronoideus á underkïken är mindre än hos Mhe, och angularprocessen är bredare och afrundal. Framtänderna uro mindre hoptryckta. Kindtanderna äo af enklare byggnad. Den 1:sta kindtanden ofran bestir af 3, och den 2:dra och 3:dje d:0 hrardera af 2 transversella lober. Den 1:sta d:0 i underkäken bestair af 4, den 2:dra af 3, och den 3:dje af 2 lober. - Harfaillen borstlik. Öronen uppstaende ur faillen, af medelnittig längd, med langt hảr å yttre sidan. Fötterna stora och breda, och undertill nakna. Sransen medelmåttig, täthàrig. - Blott en art, Phl. Cumingi, WATERHocse, frain ön Luzon. Slägtet hal fatt sitt namn deraf, att den lefver af bark.

\section{Slägtet Dendromys, Surru.}

De öfre framtänderna med en djup lingsggaende fïra å sin fiämre konvexa sida. Kindtänderna aftaga $\mathrm{i}$ storlek bakait, och den 1:sta i öferkäken dubbelt större än den 2:dra d:0. Benhufvulet liknar det af Mus, men foramina infurubitalia iro storre, och den undre grenen af processus zygomatici a öfrerkïken saknar den lamellösa utvilgningen framtill. Kroplsformen muslik. Oronen temligen stora och zppstaende. Ofverlijpen klufren. Franfötterna. hafva endast 3:ne fulstandiga tar och en rudimentär tumme. Bakfütterna äro femtaiga. Svansen lång, gleshårig, och med tydliga fjälliga hudringar (WAGNer). - - Ett par arter (D. mesomelas, Licht. \& melanotis, Smith.) från södra Afrika. Springa på träd och buskar.

\section{Slägtet Steatomys, PETERs.}

Enligt PETERS ${ }^{3}$ ) äl den af en mera undersätsig byggnad, med kortare extremiteter och kortare svans, än de af slägtet Mus. De öfre framtäuderna hafva à sin främre sida en djup

') Mus giganteus, frin Iudien, har kroppslängden 13" och svausen ungefär lika så lång; af en äldre hona, enlight WAGæER, mer hanen skall blifva betydligt större.

$\left.{ }^{2}\right)$ Proceed of the Zool. Society, 1839, p. 107.

3) L. c. p. 162 . 
lângsgaiende fîra, som är närmare intill den yttre än den inre kinten af dessa tänder. Fütter och öron likna dem af Mus, med undantag deraf, att klorna i franfötterna äro lïngre, och öronen hafva tätare harbekladnad. Den frimsta kindtanden ofvan air betydligt längre än de baida andra tillsamman, och dubbelt längre än den s:dra. Den 3:dje d:o har kronan blott $\frac{1}{2}$ millim. làng. De z:ne främsta kindtändema i underkäken likna dem af Lus, men den 3:dje är mindre. Kindtandraderna divergera starkt framit. Benhufudet liknar i alluämhet det af Mus, men foramina infraorbitalia äro störe, och nedtill lika breda, som upptill; fossa pterygoidex äro grundare, och bullæe ossex större. - 2:ne arter ( $S$. edulis \& Krebsï, Peters, från Mossambique och södra Afrika. Den förra, som är $3^{\prime \prime}-4^{\prime \prime}$ lång, blir serdeles fet, och ätes af infödingarne i trakten.

\section{Slägtet Pelomys, Peters.}

Kroppsformen lik den af Mus, med lang svans med tydliga hudringar. De öfre framtanderna med en djup langsgatende fiura a deras främve sida, nagot nämare deras yttre kant. Kindtanderna utmärlia sig genom en betydlig bredd, sâ att de bida främe a livardera sidan i öfrerkïken atminstone äro lika breda som afstandet mellan bata tandraderna, men den fränsta lıar krouan knappt sí lång, som de bida andra tillsamman, och icke dubbelt lïngre än den 2:dra d:0. Benluffudet karakteriseras genom den korta och tjocka nosen, och den mycket smala gomdelen och den breda paman, hrars minsta bredd knappt immehalles 2:ne gianger i näsbenens längd ${ }^{1}$ ). Framfötterna hafra 4 fullstandiga târ och en rudimentär tumme, men den yttersta är mycket kort, och har en hvälfd nagel. ¿ de bakre fötterna, som hafva 5 tilr, äro de báda yttersta korta, och sinsemellan nugefür lika langa. Öronen rundade, af medelmåttig längd, och framstaende ur fällen. - Endast en art ( $P$. fallax, Peters), som är 6"_7" lang, och blifvit funnen i grannskapet af Zambeze i Afrika (PETERS).

\section{Tribus Sigmodontes, WAGNER.}

\section{Slägtet Reithrodon, Waterhouse.}

De öfe fiamtånderna med en djup firra längs deras främre sida. Benhufvudet mycket likt det af Mus musculus, och temligen kort. Den öfre kanten af orbitæ skarp, och fortsatt på sidorna af hjessan med en låg kant. Foramina incisiva räcka tillbaka till de främsta kindtänderna ${ }^{2}$. - Öronen korta och föga uppstacnde ur fällen. Extremiteterna korta. Framfötterna med 4 fullständiga tar och en rulimentär tumme. Bakfütterna med 5 fullstänliga tar. Den bakre delen af lälen hirbetäckt. Svansen labrbetickt, füga liortare, eller ock längre

1) Benlufvudets form synes naira üfverensstämma med den af Isomys testicularis, Sundevalu; Kongl. Vetensk.-Akad:s Handl. 1842, p. 221, tal. 2, fig. 5.

2) De sydamerikanska arterna hafva ett starkare och bredare benhufvud, äro betydligt större, samt hafva ett stort hufvud med trubbig nos och stora ögon, och afvika derigenon frân de nordamerikanska arterna, som äro mera muslika, och hvilka torde böra bilda ett serskildt slägte. 
än kroppen. Kroppsformen af de nordamerikanska arterna muslik. — 9 arter frin Södra och Norra Amerika.

\section{Slïgtet Acodon, MEYEN.}

Öronen nästan helt och hållet dolda i fällen. Hvad MEYEN ${ }^{1}$ ) för öfrigt anförer, innebáller ingen säker karakter. Ilan uppgifver, att beskrifningen är utförd efter ett ungt djur, som :innu har den bakersta kindtanden i underkäken ofullständigt utbildad, och detta bestyrkes äfren af den ringa storleken (kroppslängden 1"-10“"). Detta slägte är derföre föga tillförlitligt, och det synes oss troligt, att det ifrägavarande djuret är en ung Hesperomys eller Reithrodon. Framtänderna beskrifias icke. Fumnen pat Perus högsläter 14000 fot öfver hafvet. Blott en art, A. boliviense, MEYEN.

\section{Slägtet Hesperomys, WATERHOUSE.}

Kroppsformen stundom (Subgen. Habrothrix, Crelomys of Phyllotis, Waterhouse; Wayn.) liknante den af Mus, och stundom nïmande sig den af Aricold, i man af öronens mer eller mindre storlek, och nosens mer eller mindre tillspetsade form. Fötterna af ranlig form, och tummen a framfötterna rudimentär sant utan utbildad klo. Tarserna äro stundom niggot förlängla. Sransen i allmänhet tiitharig, af omvexlande längd, stundom knappt sa lang som halfva kroppslängden, och stundom betydligt längre än kroppen. De afnötta kindtändermas kronor af vexlande form; stundom äro de ingirende emaljvecken djupare och stundom grumdare, stundom alternerande och stundom motsatta, men de aftaga dock allid i storlek bakait, så att den främsta är den största, och utmärka sigg icke för nigon synnerlig bredd. Då de icke äro starkt afnötta, synes a dem en langsgaende fara. Cranicts eller benhufudets form liknar i det närmaste den af Mus musculus \& sylvaticus. - Detta slägte omfattar den större delen af de Amerikanska Muride och den vila största delen af Sigmodontes, och kan derföre med rätta leetraktas sàsom den för denna grupp typiska formen, ehuru dess namm blifrit hem-

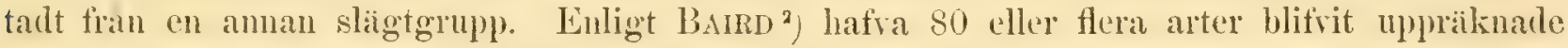
för Syd-Amerika, med inbegrepp at slägtena Holochilus och Oxumicterus. Nïr dertill lïggas 16 nordanerikanska arter, blir art-antalet für slagtet Hesyeromys, i dess vidsträicktaste omfattning, således nära 100. När derifrån dragas 6-8 arter för slägtena Holochilus \& $O x y-$ micterus, atersta omkring 90 arter för sl. Ilesperomys i nagot inskrinktare omfattuing. Sasom typiska arter kunna nämnas: H. leucogaster, Natter., H. leucopus, Rafiu., H. auritus (Desm.)

\section{Slägtet Holochilus, Brandr.}

Kroppsformen râttlik, men äferlijppen icke fullständigt klufven. Framfötterna sma och tummen rudimentär samt med ofullständig klo. Öronen täthitriga, breda och stora, men ej

1) Nova Acta Physico-Medica Acad. Caes. Leopold. Carol., rol. XVI, pars 2:da, 1833, p. 599.

${ }^{2}$ L. c. p. 236 . 
langa. Sransen korthảig och lâng, ehuru kortare än kroppen med hufrudet. Benhufvudet med smal panna och tydliga orbitallister å pambenet. Kindtänderna stora och breda, och den bakersta lika så ling som, eller läıgre än den mellersta. $\AA$ de unga äro knölarne små och den lingsgaiende färan mellan dem föga märkbar. $\AA$ de aildre förefinmas djupt ingảende alternerande och trånga emaljveck. - I allmänhet sả stora, som vair stora husrátta, eller något större. Enligt Bunmeister 4 arter från Syd-Amerika; men den ena af dessa hör, enligt PEters, till slïgtet Nectomys. Typ. H. vulpinus (Licht.); Burm. (= Mus brasiliensis, Waterh.).

\section{Slägtet Oxymicterus, WATERHOUsE. \\ (Oxymicterus \& Scapteromys, WATERHOUSE.)}

Likna till formen dem af Hesperomys, men utmärka sig genom sin spetsiga, långa, nästan snabelformigt framstående nos; genom sina lảnga och föga böjda klor it framfötternas tär, och derigenom att äfven deras tumme har en fullständig klo. Öronen äro stora, breda och rundade samt starkt hairiga; svansen medelmaittig, smal och hårig. Craniet är smalt och näsbenen äro serdeles linga; pannan utin uppstảende orbitalkanter. De afnötta kindtändernas kronor likma nyeket dem af Arvicole. - Ett par tre arter frain S. Amerika. (O. rufus Desm. \& tumidus Waterh.).

\section{Slägtet Neotoma, SAY and ORD.}

Kroppsformen râttlik. Svansen lảng, mer eller mindre täthirig. Öronen mycket stora och nästan nakna. Tummen å framfötterna nästan omärklig. Hälame hàriga. Kindtändernas afnötta kronor likna i det närmaste dem af Arvicola. Emaljvecken á den bakersta kindtanden i underkäken likna en liggande 8. Arterna af detta slïgte bilda 2:ne grupper: den ena med svansen betäckt af glesare och kortare hirr, liksom hos Dhus decumanus, och med kort nos; den andra med laing och tät hårbekladnad i svansen, och med ling nos. Benhufvudet lingstriickt med ling nos och smala och lỉnga näsben. Mellankäksbenen räcka längre tillbaka än näsbenen, och den bakre gomkanten är beliggen mellan de bakersta lindtänderna. Pannan smal, utan uppstîende orbitalkanter, och hos dem med yfrig hairbetäckning: i svansen niggot smalare vid bakre delen af orbitæ. Angularprocessen á underkikiken kort. De till detta slägte hörande Muriderna äro stora, stundom betydligt större än vâr stora huısraitta, och fürekomma alla i N. Amerika. Man küinner 6 arter. ( $N$. floridana Say and Ord och $N$. occidentalis Cooper). - (BAIRD).

\section{Slägtet Sigmodon, SAY and ORD.}

Till utseendet $\mathbf{i}$ allmänhet liknande Arvicolo. Nosen kort och trubbig. Öronen stora, men dolda till större delen i fällen. Tummen à framfötterna rudimentär. Pá bakre fötterna äro de bada yttersta tiorna mycket korta och nästan lika linga. Svansen kortare än kroppen. Fotsulorna nakna ända frän hälarne. Benhufvudet är kortare in hos föregảende, och nosen 
kortare och tjockare, men, liksom hos dessa, räcka mellankäksbenen längre tillbaka än näsbenen. Pannan är knappt så smal, som hos föregående, och är försedd med uppstiende orbitalkanter. Interparietalbenet har liungddimensionen helt liten, men deremot den transversella stor. Den bakre gomkanten, som i midten har en utstiende kam, ä stundom beligen mellan de bakersta kindtinderna, och stundom lïngre tillbaka. Kindtanderna äro aftagande nigot, men ej mycket i storlek bakat, och emaljvecken ì de 2 bakersta i mderkäken hafra formen af ett S, hvilket gifvit anledning till sligtnamnet. - Ett par arter (S. hispichs, Say a. Ord, och S. Berlandieri, Baird), ungefár hälften mindre än Mus decumanus; från södra delen af Förenta Staterna i N. Amerika (Baird).

\section{Slägtet Drymomys, Tsciud.}

Ett ofullstindigt kändt slïgte, som, liksom slïgtet Acodon, synes vara grundadt på ett yngre exemplar, möjligen någon ung Hesperomys. Kindtanderna äro knöliga, den 1:sta med 3:ne och den 2:Ara med 2:ne par knölar, och den 3:dje, som är myeket mindre och trekantig, har en treknölig upphöjd kant. De öfre framtinderna hafva a yttre sidan en tydlig långsgående fara. Ḱropusformen är muslik. - Eudast en art (D. parvulus, Tsehudi) ${ }^{1}$ ), frán Peru.

\section{Slägtet Nectomys, Peters.}

Kroppsformen råttlik; öfverlippen klufven; öronen breda, rundade, uppstående ur fillen. Sransen lang, fjallig och glesharig. Framfötterna med 4 fullstundiga tir och en rudimentïr tumme. Bakfötternas fotsula ända frân hilen fjillig, och deras 3:ne mellersta târ till 2:dra leden förenade genom simhud. Kindtinderna likna dem af sligtet Holochilus. - Enligt PETERS $^{2}$ ) ett par arter (N. squamipes, Brants \& apicalis, Peters) frăn S. Amerika.

\section{Tribus Merionides, WAGNER.}

21. Slägtet Otomys, F. Cuv.

(Euryotis, Brants.)

Detta slïgtes mest utmärkande karakter hemtas frin kindtindernas beskaffenliet. Cti ofverkïken är den bakersta kindtanden störst, och den mellersta minst. I bàda kïkarne äro deras emaljveck genomgaende och omsluta à kronan rutor eller lameller, som äro tuma, parallela och transversella, och de omslutande emaljslyngorna iro med sina tvirsidor förenade med hvarandra. I öfverkäken består den 1:sta tanden af 3, den 2:dra af 2, och den 3:dje af 3, 4 eller 7 lameller. I underkäken har den 1:sta 3-4, den 2:dra 2 och den 3:dje 2 eller

') Fauna Peruana, p. 178.

2) Abh. d. Kön. Akad. d. Wiss. zu Berlin, f. 1860 (tr. 1861), p. 151, tab. 1 \& 2. 
3 dylika lameller. De öfre och stundom äfven de undre framtänderna hafva framtill en djup langsgaiende fi̊ra, och stundom fimas 2:ne dylika firror à de förra. Kroppsformen muslik. Öronen rundade, uppstiende ur fillen, hairiga. Framfütterna med en rudimentär tumme. 5 arter från södra Afrika, enligt Wagner, och enligt P. L. Sclater ${ }^{1}$ ) en obestämd art frìn de östra delarne af mellersta Afrika. Typ O. bisulcatus, F. Cuvier.

\section{Slägtet Meriones, ILLIGER. \\ (Gerbillus, Desm.)}

Denna är den typiska slägtformen för hela den här ifrågavarande tribus, och den utmürker sig dessutom frän de andra genom en större rikedom pí lithörande arter. De ifre framtänderna hafra en djup lingsgaiende fảra á sin främre sida. Kindtunderna, som lemma de för sligtet vigtigaste karaktererna, fürete ganska betydliga skiljaktigheter efter aldern. Hos yngre exemplar förete de 2-3 af emalj omslutna, smalt elliptiska och nágot böjda transversella lameller, och längs midten af kronorna är en grund făra eller fördjupning. Vid lingre framskriden afnötning upphör à midten af kronorna grinsen mellan nämnde laneller eller rutor, och dessa sammansmälta hür, samt äro da endast antydda genom früm sidorna mer eller mindre djupt ingaiende och hrarandra motsatta reck af cmaljen. Rutomas form ar da olik den föregaiende derigenom, att de $\mathrm{i}$ mån af afnötningen erhalla allt större och större lingddimension, och füljaktligen blifva större och bredare. Craniet har den allmünna formen af craniet af Mus, men är baktill bredare, derigenom att bullæ ossæe eller tympanclbenen, ifvensom partes mastoileæ äro större. Hetatarsus är förlingd och metatarsalbenen, atminstone stundom, upptill sammanvuxna, hvaruti ligger en tendens till Dipodiderua. - Nosen spetsig med klufven öferlïp; öronen uppstaende ur fillen; framfötterna med rudimentir tumme; svansen ling och täthărig, med langre hâr rid spetsen. Kroppsformen rattlik. - Mellan 20 och 30 arter äro kända, från Afrika och Asien, de flesta från den förra verldsdelen. ( $M$. gerbillus, Oliv.; Sundev.; \& M. indicus, Hardw.).

\section{Slägtet Rhombomys, WAGNer.}

Detta slïgte sti̊r mycket nära föregående, och skiljes derifrån endast derigenom, att de af emaljrecken omslutna rutorna à kindtindemas kronor äro mera reguliera, rhomboïdiska, och derigenom att interparietalbenet har den transversellat dimensionen föga större än den longitudinella. - Enligt WAGNER $\left.{ }^{2}\right) 6$ arter, frin norra Afrika, vestra delarne af mellersta Asien och sydüstra Europa. (Rh. robustus, Wagner.)

\section{Slightet Malacothrix, WAGNER.}

De öfre framtïnderna firrade. Den 1:sta kindtanden ofvan bestir af 3:ne transversella lameller, som :iro sammanbundna genom 2:ne longitudinella utskott, hvilka liksom tvärlamel-

1) Proceed. of the Zool. Society 1864, p. 101.

$\left.{ }^{2}\right)$ L. c. p. 485 . 
lerna, ïro omgifna af en smal utlöpande kant af emalj. Den 2:dra tanden dito har 2:ne tvirlameller, förenade genom ett dylikt utskott; och den 3:dje dito är odelad. Kindtanderna i underkïken likna i det närmaste dem i den öfre. - Nosen kort och trubbig; ögonen och öronen stora, de sednare ovala, tillspetsade; extremiteterna korta; fötterna smá; svansen temligen kort, kortharig. - Enligt WAGNER ${ }^{1}$ ), ett par arter frän südra Afrika. (M. albicanduta, Smith).

\section{Slagtet Mystromys, WAGNER.}

Framtänderna slita. Kindtandernas lameller, som äro $2-3$ till antalet, äro i midten afbrutna, och alternerande, samt smala. Kroppsformen muslik. Öronen stora och breda; öfverlippen ofullstindigt klufven; fötterna likua dem af Mus; svansen af medelmaittig lingd, täthårig. Enligt WAGNER, — en art (M. lanuginosus, (Licht.)) från södra Afrika.

\section{Slägtet Psammomys, Cretzschmar \& RüPPell.}

Framtïnderna släta, liksom hos föreg. Kindtänderna bildade siosom hos Rhombomys. Öfrerlippen hel; öronen medelmittiga; fütterna lika dem af Mus; svansen kortare ïn kroppen, täthårig. Craniet baktill bredt, med stora bulla ossea och partes mastoidere, och en spetsig angularprocess al underkiken. - Blott en art (I's. obesus, Cretzschm.) frản nordöstra Afrika ${ }^{2}$ ).

\section{Slỉgtet Spalacomys, Peters.}

Kroppsformen råttlik; men lufvudet och nosen äro breda; den sednare har klufven öfrerläpp; ̈̈ronen upssticnde ur fällen, medelmattiga; extremiteterna af mattlig längd, de fräure med rudimentär tumme; klorna breda; sransen af medelmattig längd. Frantänderna breda och framtill plattade och slïta. Kindtändema bakit aftagande i storlek, den 1:sta med 3:ne, och de båda andra hvardera med 2:ne transversella lameller. Craniet med starkt utstaiende kindbảgar; med smal panna med uppstiende orbitalkanter; med tjock nos, och mellankïksbenen gáende längre tillbaka än nïsbenen; med smal gom och stora bullæ ossea. Underkäkens angularprocess mycket kort och trubloig. - Enligt Perers ${ }^{3}$ ) bildar detta slägte en mellanform mellan Lurini och Spalucini, och omfattar hittills blott en art, S. indicus, Peters, från Indien, ungefür så stor, som Mus rattus.

\section{Sectionen SMINTHI.}

28. Slägtet Sminthus, KEYSERLing \& BLAsius.

Kännes lätt genom antalet af sina kindtiinder, $\frac{4-4}{3-3}$, fran alla andra inom samma familj.

1) L. c. p. 496 .

$\left.{ }^{2}\right)$ Cretzschmar i Ruippells Atlas zu d. Reise im nördl. Afrika, p. 56, tab. 22 \& 23; Wagn. I. c. p. 494.

$\left.{ }^{3}\right)$ Abh. d. Königl. Akad. d. Wissensh. Z. Berlin f. 1860 (tr. 1861), p. 139, tab. II, fig. 1. 
Cranict är utmärkt genom de mycket stora foramina infraorbitalia, som nedtill äro bredare än upptill, och den till följe deraf lagga undre grenen af öfverkäkens processus zygomatici. Härigenom visa de en stark tendens till de Hystrichomorpha gnagarne, och denna karakter har förskaffat dem namnet Hystrichomyes af BRANDT. - Endast en med säkerhet känd art, S. vagus, Pallas, Blasius; från östra Europa och norra Asien.

\section{Sectionen, HYDROMYES.}

\section{Slägtet Hydromys, E. Georfroy.}

Äfven detta slägte utmärker sig genom kindtändernas antal, som är endast $\frac{2-2}{2}$. Craniet är lângsträckt, och liknar i det närmaste det af 1 hus, men foramina infraorbitalia äro nästan halfmånformiga. Betraktadt frản sidan, är det något konkaveradt öfver pannan. Foramina incisiva äro smá, och öppna sig endast uti mellankäksbenen. - Kroppen långsträickt och ligbent. Nosen trubbig, och öfverläpen klufven. Öronen smá, afrundade. Framfötterna med 4 fullständiga, skilda tär och en rudimentuir tumme. Bakfötterna med 5 stora och linga tảr, som, med undantag af den yttersta, äro förenade genom simhud. Deras fotsulor nakna. De bakre fötternas klor störe än de främres. Svansen lang, trind och betäckt af kort hâr. Härfillen kort. - Man har uppstallt 4 arter, af hvilka ett par, (chrysogaster $\oint_{0}$ leucoguster, Geoffroy) länge varit kända; från Vandiemensland. De äro stora, med en kroppslïngd af $12^{\prime \prime}-13^{\prime \prime}$, samt äro till sitt lefnadssätt amfibiska.

\section{Underfam. Arvicolini. BONAP.}

Denna underfamilj, som stundom rarit betraktad sisom en grupp af lika vïrde med familjen Muride, och blifvit uppstiilld sasom en egen familj, sluter sig emellertid ganska nära till en del af slägtformerna inom den föregaiende underfamiljen, och kïnnes från dem endast genom kindtändernas ofullständiga rötter, och den något afvikande formen af craniet, enligt hrad ofvan blifvit anfördt. Så t. ex. företer slägtet Sigmodon mycken habituel likhet med dem, och kindtändernas kronor hos si. Neotoma visa den närmaste öfverensstämmelse med dem hos Arvicolce. BAIRD uppgifver, att det ännu icke är utröndt, om kindtänderna hos ungar af Neotoma hafva knölig krona. De äro dock alltid försedda med fullständiga rötter. Arvicolinerna, eller Sorkarne äro fattiga på slägtformer, men förete stundom en icke obetydlig rikedom pá arter. De tillhöra icke de varmare delarne af jorden, utan blott de tempererade och kalla. Inga dithörande arter förekomma i Afrika, Indien eller S. Amerika. De fä till Arvicolini hörande slägtena uppställa vi på följande sätt:

Slägten:

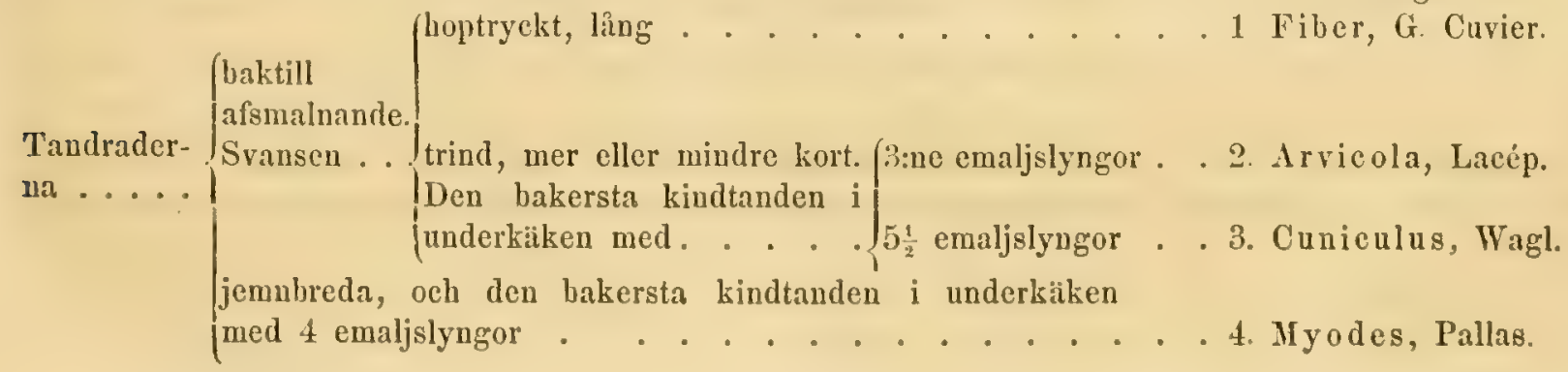




\section{Slägtet Fiber, G. Cuvier.}

Kroppsformen sorklik, men svansen är ling, vertikalt hoptryckt, glest hairbetäckt och fjällig. Hufindet bredt, nedtryekt, med något tillspetsad nos. Ögon och öron små, de sednare dolda i fällen. Fötterna hafra tima vid basen förenade genom simhud, och deras undre sida naken. Framföttemas tumme är rudimentair, men lar lock en fullständig klo. Framtima kantade med simborst. Tänderna likna dem af Avicola, men den bakersta tanden i underkïken har 5 emaljslyngor, den fränista yttre af dessa dock helt liten; den mellersta kindtanden i samma käke har 5, och den früusta dito 9 emaljslyngror. Uen främsta kindtanden i öfverkäken har 5, den 2:tra 4, och 3:dje 4 dylika emaljslyngor, och den sistnämnda är märkluart afsmalnande bakàt, med den sista emaljslyngan stor och bakit utdragen. Craniet har pannan mellan orbitae baktill starkt hoptryckt och med en langsgaiende skarp kant, som fortsättes till hjessbenens början. Pars squamosa ả timninglonen är serdeles stor, och bildar en rätt utstaente knöl bakom orbitx. Den bakre näsöppningen smal och högre än bred. Underkäliens angularprocess, silson vanligt hos Arvicolinerna, uppstigande öfer höjden af kindtandradernas bakie del. Craniet liknar i det nïmaste det af Arvicola amphibius. - Af detta ammärkningsväirda slägte har tills sednare tiden blott en art varit känd, nemligen den i pelshandeln bekanta MYskrätan eller Zibethrattan ( $F$. zibethicus, (LinNẺ)), som förekommer öfver en stor del af Nord-Amerika. En annan mindre art, $F$. osoyogsensis, från Nord-Amerikas pelsdistrikt, har för ett par tre â sedan blifvit beskrifven af J. K. LORD ${ }^{1}$ ).

\section{Slägtet Arvicola, LACÉPĖDE.}

Kindtandraderna bakàt afsmalnande, och den bakersta kindtanden i underkäken med 3:ne emaljslyngor. Svansen lika ling som, eller merendels länģe ä̉ bakre fơtterna, tätharig. Den bakersta kindtanden i ifverkiken med 5-- 7 alternerande emaljslyngor. Kroppsformen är ej så klumpig och undersätsig, som hos de băda följande slägtena, samt füreter genom de nagot längre extremiteterna en starkare tendens ait den rattlika formen. Framfötterna hafva små klor, och deras tumme är rudimentär och fürsedd med ofullständig klo, ehuru den stundom är konisk; m. m. - Af detta slägte äro omkring 50 arter kảnda, från Europa, norra Asien och N. Amerika, och häraf omkr. halfva antalet frân den sistnämnda verldsdelen. (Arv. amphibius (Lin.), glareolus (Schreb.) \& agrestis (Lin.)).

\section{Slägtet Cuniculus, Wagler. \\ (Systema. 1830).}

För en sork-art, som maı förut brukat räkna till slägtet Myodes, uppställa vi här ett eget slägte, och tilldela detta ett gammalt namu, som af WAGLER redan 1832 3) at den här ifrigavarande arten blifvit gifvet, ehuru, sisom det synes, nti en vidsträcktare bemärkelse. Till den yttre kroppsformen öfrerensstämmer den fullkomligt med Nyodes, men dess tand-

1) Proceedings of the Zoolog. Society 1863, p. 97.

$\left.{ }^{2}\right)$ Isis 1832 , p. 1220. Cuniculus groenlandicus. 
byggnad ïr en helt amnan, och genom denna sluter den sig närmare till Arviolu. Detta har föranledt oss att för den uppställa ett eget slägte.

Kindtänderna hafva alla emaljslyngorna alternerande, smala, länga och näistan jemnbreda, men de ingiende vinklarne af emaljen intränga i allmänhet icke a nagon tand längre än till tandens midt, och äro icke genomgáende, sisom hos Myodes, och den bakersta kindtanden iir i biida käkarne bakit märkbart afsmalnande. Úti denna emaljveckens alternerande och mindre djupt intrïngaude beskaffenhet öfrerensstämma de med dem af lrvicolu; men de afvika frin båda dessa slägten genom emaljveckens större antal. Den bakersta kindtanden i underhicken har $5_{2}^{1}$, den mellersta $5_{2}^{1},{ }^{1}$ ) och den frärnsta 9 emaljslyngor. Den bakersta i överküken har 6, den mellersta 6, och den främsta 7 emaljslyngor. — Craniet utmärker sig derigenom att okbenen äro svagare än hos Myodes, och pannan har en langsgraiende grop. Skelettet företer den egenheten, att mellan ulna och radius är å midten en stor öppning, och spina tubereuli majoris a öferarmen bildar en of vantill skarpt begränsad och rait utstiende process. - Svansen är kortare än bakfütterna, ach dessa hafra fotsulan härig. Framfütternas klor äro stora gräifklor, och a de 2 mellersta târna äro de stundom enormt stora, och hoflika, samt vid spetsen klufna. - En art, C. torquatus, (Pallas; Middendorff) (= Cuniculus groenlandicus, Wagler), frán nordöstra Europa, Sibirien och de nordligare delarne af N. Amerika.

\section{Slägtet Myodes, Pallas.}

Kindtandraderna jemnbreda, och den bakersta kindtanden i underkäken med 4 emaljslyngor, af hvilka de 2:ne bakre äro atskilda genom en friin inre sidan genomgacnde bugt af emaljen, samt hafra ungefiir samma transverselt elliptiska form, och äro parallela; och flen 2:dra i ordningen är helt liten och belïgen vid tandens ytre sida. Den mellersta kindtanden i samma käke hå 5 , och den främsta 5 emaljslyngor. $\AA$ dessa sednare båda tänder äro i allnänhet de inre slyngorna störst. Den bakersta kindtanden i öfverkäken har 4 emaljslyngor, af hvilka de 3 bakie äro parallela; den mellersta i dito har 4, och den främsta har 5 emaljslyngor, och de yttre af dessa à de båda sednare tänderna äro störst. $\hat{A}$ craniet har den smala pannan en långsgo̊iende crista, och okbenen äro serdeles breda. Srans och fotsulor lika med föregaendes, men klorna a framfötterna, ehuru ranligen större än de i bakfütterna och bildade för gräfning, äro nagon găng mindre ïn dessa sednare. — Endast 3:ne säkert kanda arter från Europa, Sibirien och N. Amerikas nordligare delar. (M. lemmus (Linné) fran Sverige, Norge och Finska och Ryska Lappland, vester om Hvita Hafiet).

\section{Fam. SPALACID E, BRANDt.}

Ögonen och utöronen rudimentira; nâgon gång ïro de dock litet mera utbildade, men dock mycket sma och mindre än hos de andra. Kroppsformen är tjock och undersitsig,

$\left.{ }^{1}\right)$ De båda $1 / 2$-emaljslyngorna utgöras af en vid dessa tänders främre ända iuât riktad liten emaljlamell. 
nistan cylindrisk, med korta extremiteter, ocin af dessa de fränre och bakre ungefiir lika lánga. Sransen merentels mycket kort, nâgon gâng ingen. De förete für öfrigt en betydlig rexling i form, hvilket har föranledt WATERHotse att uppstilla en del hithörande sligitformer under fam. Anvicolida, och att för andra bilda en egen familj, Bathyergide. T'ummen a tramfötterna ï stundom rudimentir, och stundom mera utbildad och med fullstindig klo. Fotsulorne kantade med styfia har. Nyckelbenen äro fullstindiga, men fibula, eluru stundom ganska stark, är nedtill sammansmilt med tibia, och demna är upptill framâtböjd. Kindtïnderna äro omvexlande sâväl till antalet som till rötternas beskaffenhet. Framtinderna äro merendels stora och framstaende, och med deras främe sida plan; samt aro behjelplige vid griifningen. Intestinum coecum förefinnes. - Benhufundet ar underkastadt betydliga formskiljaktigheter; stundom visar det en nira ofverensstimmelse med det hos Arvicolinerua, och stundom företer det en mirkbar tendens till Saccomyidema, och t. o. m. till de Hystrichomorpha gnagarne. - Oaktalt alla dessa formskiljaktigheter, öfrerensstimma dock alla hithörande forner uti att föra ett underjordiskt lefnadssitt, liksom Mullvadarne, och ega en serdeles stor förmåga att grïfra. Liksom de af föregående familj, äro de i allmänhet af ringa storlek. De tilliöra alla den Gamla Werlden, och förekomma i Europa, Asien och Afrika.'

De hithörande slägtena äro, enligt BRANDT, till antalet 8, och den här bifogade tablin lemnar en öfrersigt öfver dem.

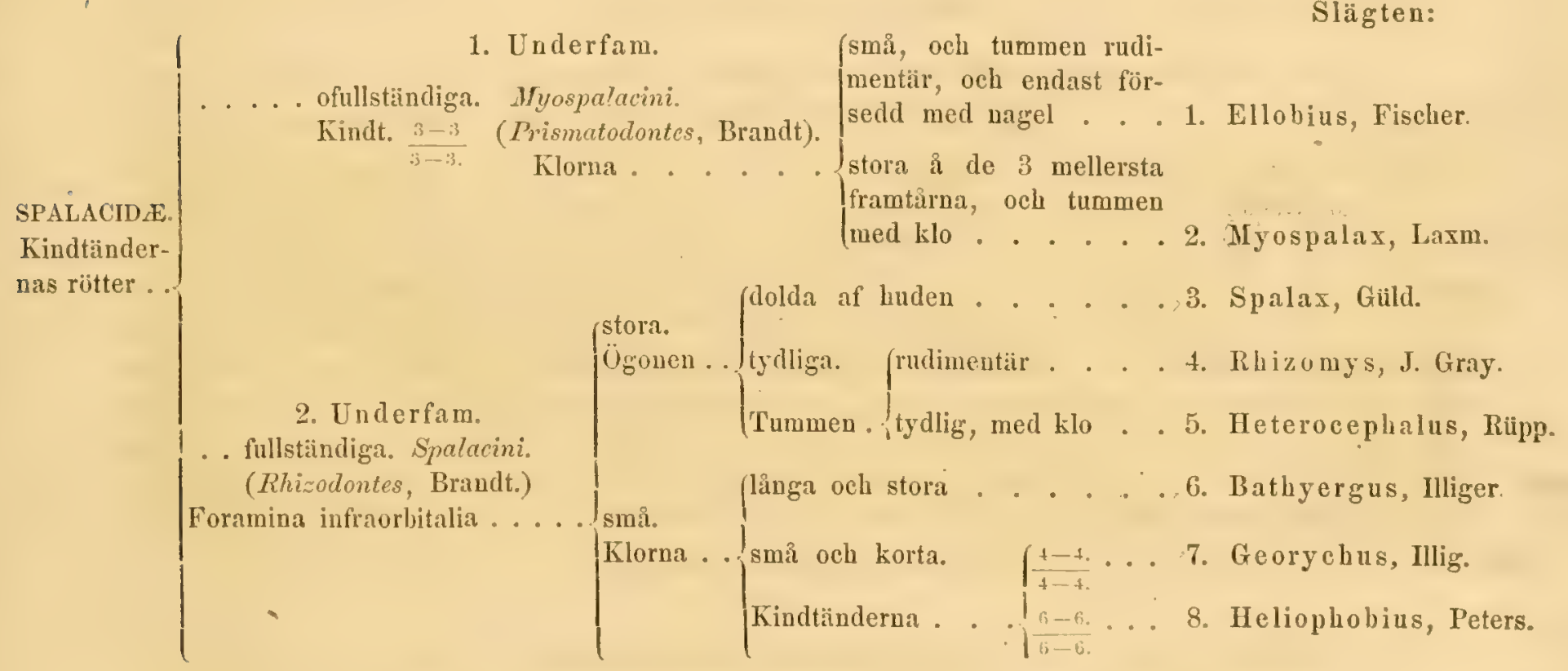

1. Underfam. Myospalacini.

(Prismatodontes, Brandt).

Kindtändernas rötter ofullständiga. 


\section{Slägtet Ellobius, Fischer.}

Framtänderna framtill slita. Kindtänderna $\frac{3-3}{3-1}$, bakit aftagande i storlek, strecktecknade, och med livarandra motsatta grunda bugter af emaljen. Craniet liknar mistan fullkomligt det af Arric. amphibius, men har nagot litet bredare pama och mindre bakre nisöppning. Foramina infraorbitalia medelmáttiga, nüstan ovala, och upptill bredare. Den undre grenen af öfverkäkens processus zygomatici skrifformig, men icke strïckt framait, och smalare än hos Arricola. Ögonen obetickta, men utöron saknas. Tummen ì framfötterna rudimentïr och med ofullständig klo. Sransen mycket kort. - En art, E. trel,inus, G. Fischer, frin södra Ryssland och sydvestra Sibirien.

\section{Slägtet Myospalax, LAXMAN: \\ (Siphneus, Brants.)}

Framtänderna slita. Kindtänderna $\frac{3-3}{3-3}$, knappt aftagande i storlek bakăt, strecktecknade, men nïstan endast i̊ endera sidan wed ingíude reck af emaljen. Craniet, som till sin form ritt mycket liknar det af Spalux, har nackbenet nigot litet lutande framat, si att den rinkel, som bildas af detta bens pars basilaris och pars occipitalis ar nigot mindre än en rit. Vid suturen mellan nackbenets pars occipitalis och lijessbenen och timningluenen ar en hög kam (crista lambdoidea), frìn hrilken craniets kontur, sedd frín sidan, stupar till nosens spets, med endast en helt liten konkavering öfver paman. Okbenet temligen smalt. Den nedre grenen af processus zygom. it öfverkäken bred, skifformig och framait riktad. Foramina infraorbitalia sma, trekantiga oeh nedtill smalare. Underkiken med en myeket kort och uppait riktad angularprocess, som utgär fran underkäkens undre kant. Processus coronoideus lika hög, som processus condyloideus. Ögonen myeket smá, men obetiickta; ntöronen ïro endast en liten hudflik; de 3 mellersta tairna a franfötterna med serdeles stora och långa klor, och tummen äfven med klo; svansen myeket kort och naken. - Lin art, M. talpinus, (Pallas), friin Altai.

\section{Underfam. Spalacini. (Rhizodontes, BrandT.)}

Kindtändernas rötter fullständiga.

\section{Slägtet Spalax, Güldenstedr.}

Framtänderna släta. Kindtänderna $\frac{3-3}{3-3}$, nästan likstora och cylindriska, med veck eller üar af emaljen. Kroppsformen nästan lik mullvadens, med stort hnirnd och korta ben. Nosen med en broskskifva. Ögonen taickte af huden, utöronen otydliga, och ingen svans. Tummen a framfütterna tydlig, med klo, men kort; tirna eljest starka, men med korta klor. De främre extremiteterna starkare än de bakre. - Craniets form är serdeles utmärkande. Det är mycket bredt, så att största bredden öfver okbenen är större än $\frac{3}{4}$ af craniets längd (hos äldre exemplar). Dess öfre kontur, sedd frain sidan, ïr frim nacken till nosspetsen stupande nedat. Nackbenets pars occipitalis är mycket stor, och strücker sig med sin öfre 
snedt uppait och framăt riktade del öfver midten af sjelfva lijernkapseln. Vid dess öfre gräns är en hög crista lambloidea. De båda hjessbenen äro mycket små, och i midten takformigt uppstiende. Interparietalbenet otydligt. Pannan är smal. Okbenen äro smala, men ofverkäkens processus zygomatici äro stora, och foramina infraobitalia äro stora och halfmånformiga, samt nedtill nagot bredare. Nosen är temligen lang och bred. Cnderkaken är tjock och stark, och vid yttre sidan af processus condyloideus är en stor och vid spetsen rund process, som har utseende af en 2:dra condyloül-process, och som gör att unlerkïkens uppstigande gren synes klufren. Denna process är den här förlingda alveolardelen för framtanden. Processus coronoideus är hög och spetsig, men angulardelen är afrundad, och angularprocessen är helt liten, och är fästad vid yttre sidan af den nämnle stora yttre alveolarprocessen. Nyckelbenen äro smala, men öfver- och underarmens ben äro serdeles grofva, och å det föra bildar erista deltoidea en hakformig process. Enligt BuAsics ${ }^{1}$ ) blott en art, Sp.tuphlus, Pallas, från sydöstra Europa, och vestra delarne af mellersta Asien. Lefver som Mullvaden, men förtiar blott regetabilier.

\section{Slägtet Rhizomys, J. GraY.}

Frantänderna släta, framtill afrundade, Kindtänterna $\frac{3-3}{3-3}$, temligen lika dem af Spalıa. Ögonen sma, men tydliga. Öronen äfrenledes tydliga, men myeket korta, ringformiga eller runda och nakna. Tummen å framfötterna rudimentair. Klorna korta. Svansen merlelmittig eller kort, naken. Foramina infraurbitalia stora. Enderkikens angulardel afrundad. Pars occipitalis lodrit. Pannan bred, plattad, och hjessbenen med crista sagittalis. - $2-3$ arter från Malacea och Abyssinien. (Rh. decan, (Temı.)).

\section{Slägtet Heterocephalus, RưPPELL.}

Framtünderna slita. Kindtinderna $\frac{3-3}{3-3}$, cylindriska, med 2-3 transversella och genomgáende emaljveck. Foramina intraorbitalia temligen stora. Nïsbenen strücka sig langre tillbaka än öfverkäksbenen. Bulla ossex små. - Kroppen nästan naken. Inga utöron. Tummen tydlig, med klo. Sransen kort. - En art, H. glaber, Riipp., som förekommer i de till södra Abyssinien gränsande trakter.

\section{Slägtct Bathyergus, ILLIGER. \\ (Orycterus, F. Cuv.)}

De öfre framtinderna med en långsgånde fara å deras främre sida. De undre framait sträckte. Kindtünderna $\frac{4-4}{4-4}$, bakåt aftagande $\mathrm{i}$ storlek, med kronorna af en oralt-elliptisk form, och efter någon afnötning enkla. Craniet med pars occipitalis nistan lodrät; interparietal-benet smalt och i midten framat tillspetsadt. Foramina infrarbitalia temligen sma. Gomlivalfvet mellan tandraderna mycket smalt, och smalare än tündernas bredd. Under-

1. Naturgeschichte d. Saiugethiere Dentschlands, p. 402. 
kikens angularprocess mycket stor och hög, med trubbig och uppait böjd spets, samt utgảende (liksom hos de Hystrichomorpha gnagarua) fion alveolardeleus yttre sida. Processus coronoideus liten. Ögonen obetỉekta, men utöron saknas. Framfötterna med långa klor, och tummen äfveu med klo. Svansen mycket kort, med tät, strâlformig hirbekladuad. - 1 art, B. maritimus, (Gmel.) från södra Afrika. Kroppslängden 16“, eller något mera.

\section{Slightet Georychus, ILLiger.}

Framtänderna släta. Kindtänderna $\frac{4-4}{4-4},{ }^{1}$ ) stundom med och stundom utan grunda bugter af emaljen. Craniet är bredt, med isymmerhet baktill starkt utstânde kindbigar. Interperictalbenct litet, triangulärt. Pars occipitalis föga lutande framât. Craniets öfre kontur kullrig. Pamman temligen bred. Foramina infrarbitalia mycket sma. Os zygomaticum smalt. Mellankïksbenen räcka längre tillbaka än näsbenen. Underkäkens angulardel liög och afrumdad, samt utgarende fram alveolatelelens yttre sida. Processus coronoideus och condyloideus låga. - Ögonen mycket små, någon gång tảckte. Inga utöron. Tummen å framföttema fullstindig. Klorna smá. Svansen mycket kort, med stralformig liabeklaidnad. Enligt J. GraY, 6 arter från södra och mellersta Afrika. (G. copensis (Pall.)).

\section{Slägtet Heliophobius, Peters.}

Framtänderna släta, framstående. Kindtänderna $\frac{6-6}{6-6}$, stundom $\frac{5-5}{5-5}$, då den bakersta ännu icke liunnit blifva utbildad, af samma form, som hos föreg. slägte. Ögonen mycket små, och utöron saknas; svansen mycket kort, harig. Franfoutternas tumme fullstaindig, och alla fötterna med 5 tår. Klorna små, de på bakfötterna längst. - Craniet liknar i det närmaste det af Georychus, men har doek nagra egenheter. Pars occipitalis är märkbart lutande framait, och begrainsas upptill af en tydlig crista lambdoidea. Fran paman till nackbenet gair en crista sagittalis. Näsbenen räcka lïngre tillbaka än mellankäksbenen. Fissura orbitalis ä myeket smal och betäekt af den densamma baktill begränsande skarpa kanten. Den bakre nïsöpningen temligen bred, och dess framre kant (bakre kanten af gombenen) ligger myeket närmare intill de bakersta kindtänderna än till bulla ossea. Gommen myeket smal. Linderkäken liknar den af föregånde slägte, men processus coronoideus är högre, än hos $G$. $c a-$ pensis. - Blott en art, II. argenteocinereus, Peters, från Mossambique. Kroppsl. 7"—8".

\section{Fam. DIPODID E, JÆGER.}

De till denna familj hörande gnagare äro utmärkta genom sin förmåga att tag’a utomordentligt langa sprâng, 20 ganger, eller flera, lingre ä deras egen kroppslingr. Denna

1) J. Grat, Proceed. of the Zool. Society 1864, p. 123, uppgifver, att en del arter af detta slägte hafva 3, och andra 4 kiudtỉnder å hvardera sidan i băda käkarne; men J. A. WAgner, Schreb. Säugethiere Suppl. 3:e Abth., p. 369 \& 370 , har redan förut upplyst, att denna skiljaktighet $i$ antalet af tänderna hos olika individer har sin grund deri, att den bakersta tanden först sent framträder. 
fömåga beror derpai, att deras bakre extremiteter erlállit en ovanligt stark utveckling och blifvit mycket langa och stora. De framre extremiteterna, som vid deras linga hopp snarare äro dem till hinders, hafva $\mathrm{i}$ samma main blifvit hämmade $\mathrm{i}$ sin utveckling, som de bakre blifvit befordrade, och de äro derföre merendels helt smả. De förete äfven det inom denna ordning enda exemplet pai en fullstaindig sammanväxning af metatarsalbenen. Hos de fleste airo nemligen de 3 mellersta metatarsalbenen sammanvuxna till ett enda ben, som har mycken likhet med metatarsen hos foglarne, bärande vid sin nedre ända 3 :ne ledknappar. Hvad benlufiudets form beträffar, skilja de sig, sasom vi redan ofvan anfört, merendels fran de andra Myomorpha gnagarne grenom de mycket stora foramina infraorbitalia, som äro bredare nedtill, och framom dessa äro öfverkäkens sidor aldrig försedda med nígon framstaende konvexitet. Pannan är bred. Epistropheus och de följande halsvertebrorna merendels sammanvuxua. Clavicula fullstandig, men fibula ofullstindig, eller nedtill sammansmält med tibia. Blindtarmen stor.

Denna familj är icke rik på former, men har dock en ganska vidstrïckt geografisk utbredning, och representanter för densamma anträtfias i Europa, Asien, Afrika och Norra Amerika.

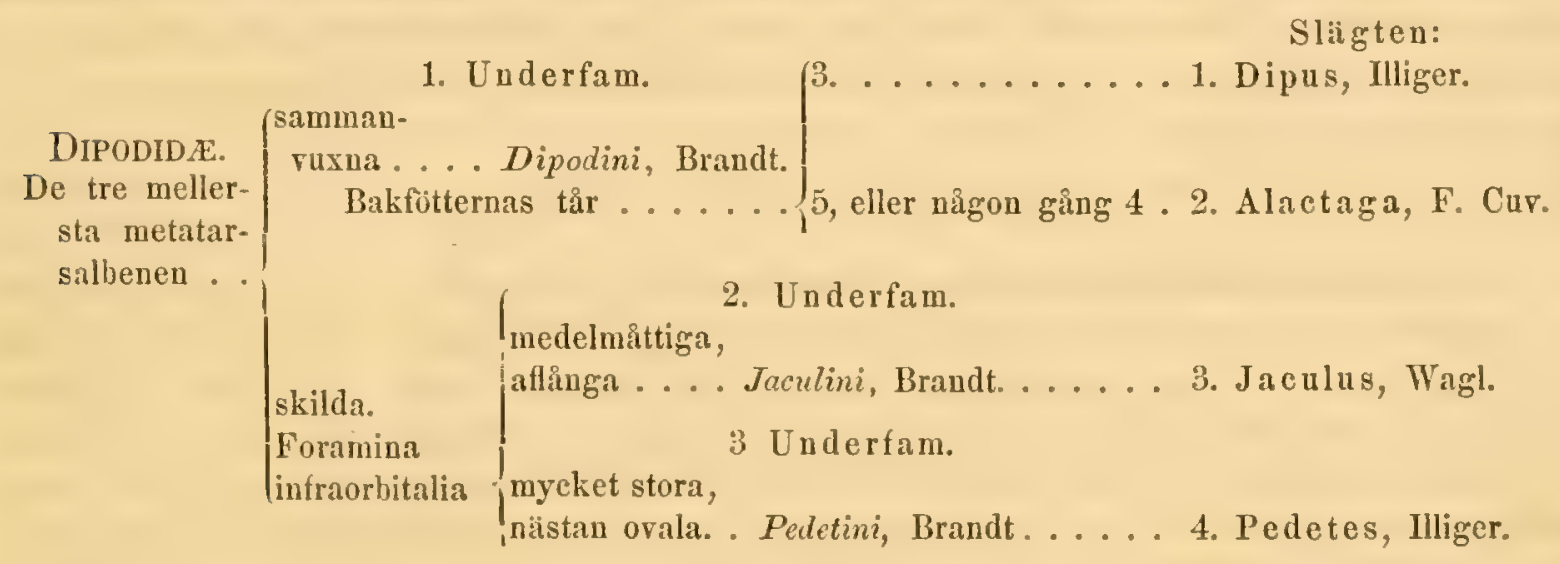

1. Underfam.

1. Underfam. Dipodini, Brafnt.

Denna underfamilj omfattar de flesta och de typiska formerna af familjen, livilka kännas genom den starkt utvidgade bakre delen af craniet och de stora bullæ ossa, derigenom att foramina infraorbitalia, som äro störe än näsöppningarne, nedtill hafva en serskild kanal för nervus infravbitalis; att underkäkens angularprocess är genombruten; och genom de 3:ne sammanvuxna metatarsalbenen, ete.

\section{Slägtet Dipus, Illiger.}

De öfre framtänderna finrade. Kindtänderna $\frac{n-9}{3-3}$, bakait aftagande i storlek och il livardera eller endera sidan med ett eller ett par ingaiende emaljveck. Ögon och öron stora; öferläppen klufven. Eramfötterna mycket sma, med 4 fulständiga tar och en rudimentiir 
tumme. De bakre extremitetena flera (omlsr. 6) ginger längre än de främre, med endast 3 tîr och ett enda metatarsalben. Undre sidan af taina med långt, borstlikt hår. Sransen lâng, täthårig, och vid spetsen med tvâsidig harpensel. - Omkring 7 arter från sydöstra Europa, Asien och Afrika. (D. aegyptius, Hasselqv.)

\section{Slägtet Alactaga, F. Cuvier. \\ (Scirtetes, Wagn.)}

Framtinderna släta. Kindtänderna $\frac{4-5}{3-5}$, fög eller icke bakât aftagande i storlek, med ingânde bugter af emaljen a bida sidor. Tandraderna divergerande framât. Framfötterna lika med föregâende. Bakfötterna med 5, eller någon gaing 4 tår, af hivilka blott de 3 mellersta stödja pât marken, och endast dessas metatarsalben äro sammanvuxna, och sidotimas äro fria. För öfrigt likna de dem af föregående slägte. - Enligt Wagner 11 arter från samma trakter, som fơregaiende, de flesta dock från Asien. (A. jaculus, Pallas.)

\section{Underfam. Jaculini, Brandi.}

Foramina infraorbitalia, och öronen medelmaittig’a.

\section{Slägtet Jaculus, WAGLER.}

De öfe framtänderna fårade, hoptryckta. Kindtänderna $\frac{b-6}{-}$, strecktecknade. Cranict baktill icke serdeles bredt. Bulle ossex sma. Foramina infraorbitalia af medelnatig storlek, aflinga. Craniet till formen stitende midtemellan Dipudilernas och Dyoxidernas. - Nosspetsen harig; öronen medelmâttiga. Framfötterna myeket sma, med rudimentär tumme; bakföttema med 5 tirr, som hvardera har sitt egna metatarsalben, hvilka således äro 5 . De 2 yttersta taina mycket kortare än de andra. Fotsulorna nakna. Svansen mycket lăng, tillspetsad och korthairig. - Enligt BAIRD blott en art, J. hulsonius (Zimmermamm), som ail utbredd öfver en stor del af N. Amerika, från Stora Slafsjön och Labrador söderut.

\section{Underfam. Pedetini, Brand:.}

Bakre extremiteterua med 4 tirr och 4 skilda metatarsalben, och, benlufvulet kort och trubhigt, med mycket bred panna och serdeles stora foramina infrorbitalia, som upptill äro smalare, och neltill sakua den lilla kanalen för nervus infraubitalis. - Fin mycket afvikande form, som tenderar bide it Hystricider och Leporider.

\section{Slägtet Pedetes, Iligiger.}

Framtänderna släta, breda och korta. Kindtänderna $\frac{4-1}{-1}$, i endera kanten med en ingående bugt af emaljen. Craniets form är serdeles egendomlig. Pannan är framtill nïstan lika bred, som craniets bredd öfver de stora ossa mastoidea. Bulla ossex äro icke af nigon 
ovanlig storlek. Den öfre grenen af processus zygomatici å öfrerkäken har den vertikala dimensionen större än den horisontella, och den nedre grenen är strüickt framåt, så att dess främre ända är nästan öfver bakre kanten af de öfre framtänderna. Nosen är bred och trubbig, ehuru dess löjddimension är större än den transversella. Underkäken är kort och dess uppstigande gren liknar i det närmaste den hos Leporida. Angularprocessen är kort och trubbig. Saisom ett rudiment af stortans metatarsalben finnes, enligt OwEx, ett aflangt ben fiistadt vid inre sidan af det imnersta metatarsalbenet. - Hufrudet liknar nagot hararnes. Öronen äro stora, linga och tillspetsade. Franfötterna ha 5 fullständiga tar. Klorna á de bakre fötterna äro nästan klötlika. Sransen li̊ng, täthårig, utan qvast vid spetsen. - En art, $P$. caffer (Pallas), frain södra Afrika. Kroppslängden näira $1 \frac{1}{3}$ fot.

\section{Familjen MYOXID E, WATERHodse.}

De fataliga till demna familj hörande former hafva af äldre författare vanligtvis blifvit räknade till ckortamiljen, pai grund af den habituella likheten mellan dem och ekorrarne, och öferensstammelsen uti lefnadssätet. Af sednare författare, t. ex. WATERIOUsE och BRANDT, hafva de dock fitt sin raitta plats anvisad bland de Myomorpha gnagarne, med hvilka de ofverensstänma bade uti benhufudets byggnal och uti förhallandet mellan underbenets baida ben. Den gamla förestallningeen om deras nära frändskap med ekorrarne har encllertid san-

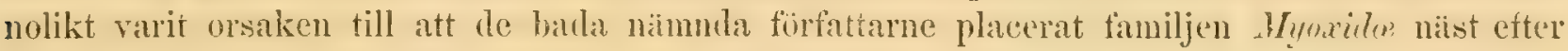
familjen Sciuridoe. I cnlighet med de af oss framställda åsigterna om platsen för den sistnämmla familjeu anse vi, att Saccomyiderua och Castoridema pá grumd at̉ benhufudets byggnad böra fil sin plats mellan denna och Myoxiderna; och detta sa mycket snarare som vi inom Dipodiderna hafva en form, Juculus, son uti samma byggnad företer en märkbar teudens till de sechare.

Med undantag af formmina-infraorbitalia öfverensstämmer benlufvudets form med Muridernas, och ofverkäkens sidor äro vid foramina infraorbitalia till en del membranösa. Pannan air inknipen och smal mellan orbitx och saknar piocessus postorbitales. Processus zygomatici a ifferkizken äro delade genom medelmattigt stora, nistan halfmantomiga foranuma infraorbitalia, och deras bidla grenar äro vertikalt hoptryekta. Foramina infraorbitalia förete icke nedtill någon serskild kanal för nervis infraorbitalis. Underkäkens form är den för Muridema och Sciuriderna vanliga, med en temligen ling angularprocess, som utgår frỉn underkäkens undre sida. Claricula ä̀ fullständig, men filuula är nedtill sammansmält med tibia. Intestimum coecum saknas, hvilket för denma fimnilj är utmärkande. Kindtänderna äro $\frac{s-\downarrow}{4-6}$, och deras kronor mer eller nindre fyrkantiga, plana, samt med transversella emaljveck, och deras rötter äro fullständiga. - Den yttre kroppsformen företer naigon likhet med Ekorrarnes, men äfen med somliga af de Hystrichomorpha guagarnes, t. ex. Petromys. Tummen å framfötterna är rudimentär. Svansen är ling, ned tuat och mer eller mindre ling hairbeklädnad. Af denna familj hafia vi blott ett sliggte:

$$
\text { My oxus, SCHREbLR, }
$$

med omkring 12 arter, fian Europa, Asien och Afrika. (Subgenera: Glis, Muscartinus, Eliomys och Grophidums.) 


\section{Familjen SACCOMY ID E, BAIRD.}

En del af de till denna familj hörande slïgtformerna hade redan förut af GiebEL ${ }^{2}$ ) och BRANDT2) blifvit upptagna sissom bildande en serskild familj, som af den föra fitt namnet Sciurospalacini, och af den sednare namnet Sciurospalacoüdes, såsom utgörande en mellanform mellan Sciurider och Spalacider: men det tillkommer BAIRD ${ }^{3}$ ) att först riktigt hafia uppfattat och begräinsat denna fanilj. Nigra af dithörande former hade före honom blifvit förda dels till Muriderna, dels till Spalaciderna, och dels slutligen till Dipodiderna.

De till denna familj hörande gnagrare kïmnas derigenom, att de hafra stora yttre kindpâsar, samt odlelade processus zygomatici a öfverkäken, fullständiga nyckelben, men ofullständiga, eller med skenbenen nedtill sammansmälta vadben (fibula). Svansen är af vanlig, trind form. Öfverliippen harig, icke klufien. Fötterna i allmänhet med 5 tår, med fullständig klo å lvarje tå. Intestinum coecum fürefinnes. Kindtänderna äro ${ }_{4-4}^{4-4}$, stundom med fullständiga, och stundom med ofullständiga rötter. Pambenen sakna postorbitalprocesser. - De tilliöra Central- och Nord-Amerika.

BAIRD afdelar familjen i 2:ne underfamiljer, af hvilka den ena tenderar ât Spalaciderna, och den andra it Dipodiderna. Han kallar den första Geomyince, och karakteriserar den dermed, "att de bakre extremiteterna äro korta, och klorna ă de främre äro mycket stora; svansen kort, och mastö̈dlelen af timningbenet bildar icke nĭgon del af craniets öfre 5 ta." Den andra underfamiljen, som kallas Seccomyino, karakteriseras af honom dermed, "att de bakre extremiteterna äro serdeles linga, främre fötterna af medelmattig storlek (inklusive klorna); och mastoüdbenen äro mycket stora, och intaga en stor del af craniets üfre yta." Endast 4 säkert kända slägten höra hit. Ett 5:te slägte, Saccomys, är för längre tid sedan beskrifvet af $\mathrm{H}$. CUVIER ${ }^{4}$ ), men beskrifingen är, såsom BAIRD anmärker, så ofullständig, att dess förhållande till de andra icke kan deraf med säkerhet utrönas. De 4 slägtena karakterisera vi, i öfverensstämmelse med BAIRD, sillunda:

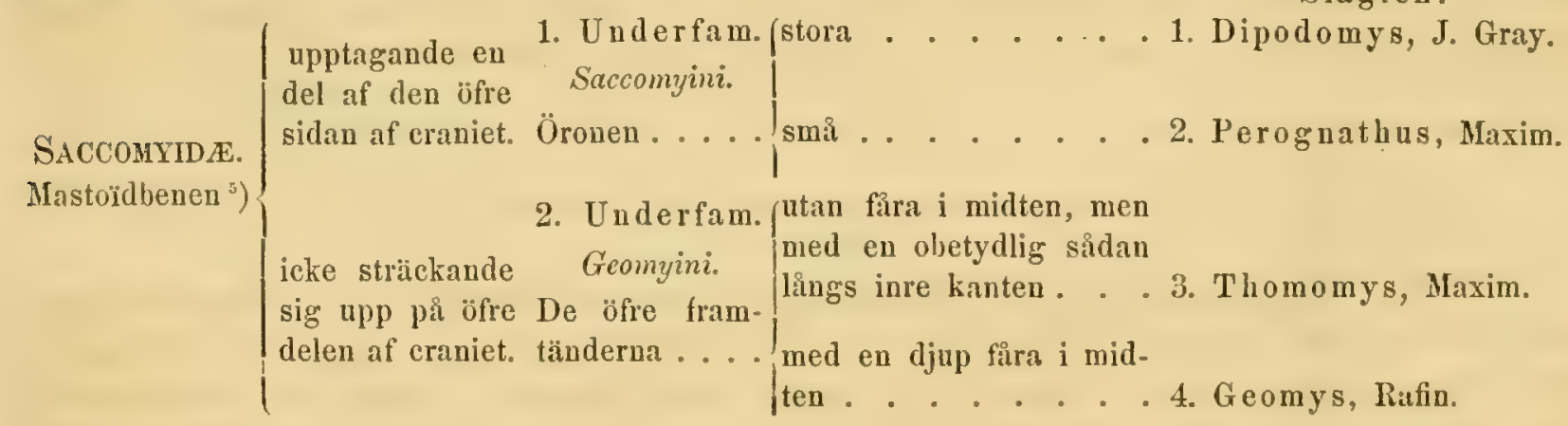

Slägten:

1) Die Säugethiere, p. 528.

2) Untersuchungen uiber die craniol. Entwickelungsstufen d. Nager d. Jetztzeit, p. 301.

3) Mammals of North America, p. 365.

4) Mémoires dı Muséum, T. X, p. 419.

$\left.{ }^{5}\right)$ Det ben, som af Baird kallas mastöidbenet, synes, enligt hans teckningar, bestå såväl af detta ben, i inskrïnktare bemärkelse, som af tegmen tympani, lvilket seduare här aì serdeles stort. 
1. Underfam. Saccomyini, BAIRD.

\section{Slägtet Dipodomys, J. GRAY ${ }^{1}$ ).}

De öfre framtänderna ¿̊ främre sidan med en lingsgående fära. Kindtanderna med ofullständiga rötter, i början knöliga. Den frümsta kindtanden i hvardera küiken ömsas, och innan den blifvit fälld : d. v. s. den af mjölktandsdentitionen) har den fullstaindig rot. Benhufvudet företer en serdeles egendomlig form, som till en icke obetydlig grad erinrar om den hos Dipus. Dess bakre del är serdeles bred, och uppsvälld genom den starka utvecklingen af timningbenen, isynnerhet deras tympanal- och mastoïd-delar. Dessa äro utstiende sáväl pai sidorna ntom de spensliga och räta okbenen, som baktill längre tillbaka än det mellan dem inklämda lilla nackbenet, och de upptaga äfen en betydlig del af hjernkapselns öfe sida utanför de bakiat tillspetsade hjessbenen. Da benhufvudet betraktas ofranifrain, är derfüre dess bakre kontur midtför nackbenet konkav. Pannan är mycket bred, men nosen är smal, och näsbenen äro framstảende långt framom mellankäksbenen; men dessa sechare sträcka sig längre tillbaka, än de förra. På sidorna af öfverkïken, vid suturen mellan öfverkäksbenen och mellankäksbenen, är ett stort hăl, som öppnar sig direkt in uti näskaviteten, hvilket hål af BAIRD anses vara homologt med foramen infraorbitale, af livilket eljest icke förefinnes nígot spår. Underkïken är liten och spenslig. Condyloïdprocessen är störst, och har à sin yttre sida vid basen en knöl, som utmärker den bakre ändan af framtandens alveolus. Angularprocessen är tydlig, och uppstigande. Processus coronoideus äl liten. -- Ỏgonen och öronen äro stora. Franfötternas tumme är rudimentär, men dock med klo; sá är äfven förhållandet med den innersta tän a bakfötterna. Metatarsen är betydligt fürlängd, ungefär såsom hos Meriones, men alla metatarsalbenen äro skilda. Sransen lika lång som, eller längre än kroppen, tätharig, med harqvast vid spetsen. De bakre fotsulorna hariga. — Enligt BAIRD, 3-5 arter från Central- och N. Amerika (D. ordii, Woodhouse).

\section{Slägtet Yerognathus, Pr. Maximilian.}

De öfre framtänderna fiurade. Kindtänderna med fullständiga rötter, i början knöliga, derefter med plan krona. T'inningbenen äro icke så stora, som hos föregående, och nackbenet bildar jemförelsevis en större del af eraniets bakre kontur. Cranict har derföre bakre delen smalare än hos förra, och pamnan icke heller si bred, och dess torm är sâlunda mera langsträckt. -- Öronen äro små, och tummen ¿ framfütterna och den innersta tån å bakfötterna rudimentära. Sransen korthárig, ungefär af kroppens längd. - Enligt BAIRD, 6 arter från Mexico och Förenta Staterna. (P. penicillatus, Woodhouse).

1) Hacrocolus, J. A. Wagner sammanfaller bärmed, enligt Baird. 


\section{Underfam. Geom yini, Baird.}

\section{Slägtet Thomomys, Prins Maximilian.}

De öfre framtånderna, som äro stora, ha den främre sidan plan eller litet konvex, och med en liten fûra långs inre kanten, hvilken füra stundom är otydlig. Kindtänderna med ofullstäıdiga rötter, och med af emalj omsluten krona, och som, med undantag at den frïmsta, knappt förete någon bugt af emaljen. Den främsta har à hrardera sidan en ingíende, den andra motstitende bugt; de andra aro nästan cylindriska. Benhufvudet, som liknar det af Arvicolini till formen, och är af stark byggnad, har timningbenets mastoüddel och nackbenet formade sissom vanligt, och det sednare bildar craniets bakersta kontur, men tinningbenens partes squamosx ha erhillit en serdeles stark utveckling, sả at de möta hvarandra jä höjclen af craniet, och hos üldre individer der bilda en crista langs sutura sagittalis, samt till större delen dölja hjessbenen, hvilka endast baktill ofvan nackbenet blifva synliga. Pamnan är smal, och pambenen äro baktill mellan orbite starkt inknipna. Öfverkäkens processus zygomatici aro starkt utstiende, och benhufudets bredd öfver okbenen är betydlig. Nosen ar läng och smal, pai sidorna med oafbrutna benväggar, och näsbenen rä́cka knappt framom mellankikksbenen, och dessa sednare gâ längre tillbaka än de. Foramina infrarbitalia äro sma, beligna framom basen af processus zygomatici. Foramina incisiva iro ïfen sma, samt endast beligna uti mellankiksbenen. Underkiken är kort, med en ohetydlig angularproeess, men med en ling och smal coronoüdprocess, som höjer sig öfrer condylö̈lprocessen, och der ar vid basen af denna sednare en knöl, som antyder grimsen für framtandens alveol. De främre extremiteternas ben äro något gröfre än de bakres. Clavicula är stark; olecranon är mycket läng; fibula är sammansmilt med tibia nigot litet under midten af dema sednare.Nosen (med huden) kort och trubbig. Öronen mycket sma oeh till stor deldolda i fillen. Svansen ungefir af halfva kroppslänglen. De frimre extremiteterna kortare in de bakre. Kroppen tjock och undersaitsig; nistan sísom hos Spalaciderna. - Enligt BAIRD, S arter frin Fürenta Staterna och Mexico. (Th. bulbivomes, Leconte). Till lefuadssïttet öfverensstimma de med mullvadarne och Spalaciderna.

\section{Sliigtet Geomys, Rafinesque.}

De likna mycket dem af föregående slïgte, och skilja sig frain dem enlast derigenom, att de offe framtinderna hafva en djup fiura lang's midten af deras frimre sida; att de bakre. extremiteterna knappt äro längre in de främre, och dessas klor äro nagot störe; och att den frïmsta kindtanden i öfrerkiken lar den frimre emaljslyngan eller afdehingen unģufir lika stor som den bakre, dil den deremot är mindre hos Thomomys. Klon ì den 3:dje tån å framfötterna är serdeles stor. - Enligt BAmD och PETERS, 8 arter från Mexico och Förenta Staterna öster om Rocky Momntains, samt möjligen i C'entral-Amerika. (C. bursurus, (Shaw)). Föra samma lefuadssitt, som föregáende. 


\section{V1. Familjen CASTORID E, J. GRAY.}

Denna familj skiljes från alla de andra derigenom att svansen är horisontelt plattad, naken och fjällig. Den är den sista linken i kedjan af de Myomorpha gnagarne, och den allmänna kroppsformen öfverensst:̈mmer temligen väl med den af de laggbenta formerna at Muriderna, nemligen Arvicolinerna, eller möjligen ïmu mera med den af den sista aftehningen af Saceomyidema, eller Geomyinema, churu dessa scdnares frïmre extremiteter aro mera utbildade för gräfning.

De yttre karaktererna ïro så väl künda, att vi icke dermed behöfva sysselsätta oss. Kindtänderna äro $\frac{4-1}{4-1}$, aftagande $\mathrm{i}$ storlek bakat, och med ofullstandiga rötter, med undantag af den främsta, som sisom mjölktand har delad och sluten rot. $\Lambda$ de öfre kindtänderna äro på inre sidan, och å de undre på yttre d:o en vertikal grop, som är bildad af ett mer eller mindre djupt och-böjdt ingaiende emaljveck, och på den motsatta sidan af tanden äro 3:ne djupt intrüngande smala och nâgot slingriga emaljveck, af hvilka pai den bakersta tanden i öferkiiken det frimsta veeket sammanlïper med det frän inre sidan inträngande, sal att detta blir genomgiende. $P_{\mathfrak{i}}$ den sidan af tanden, der de 3:ne emaljvecken intrïnga, äro 3:ne myeket grumda vertikala gropar. Den bakersta kindtandens i underkiken emaljveck likna de andra, utom det, att niggot af dem vid starkare nötning blir insulart. Siidana äro emaljvecken hos äldre exemplar. Hos yngre har jag funnit nagon olikhet deruti, att it 1 :sta och 2:dra kindtünderma i öferkiken det fran inre sidan intringande recket sammanlöper med det mellersta af de 3:ne yttre. A underkäkens 1:sta, 2:dra och 3:dje tand är ett msulärt veck vid inre sidan af kronan. En liknande form af emaljvecken àterfinna vi endast hos slightet Myrontumes, och detta i förening med dess för simning bildade bakre extremiteter föranledde t. o. m. WAGNER att räikna detta slägie till Castorid-faniljen.

Benhufvudets byggnad är nti flera delar utmärkande för Castoriderna ${ }^{2}$ ). Den är starkare än hos de flesta andra gnagare, hvilket äfren harmonicrar med de enormt stora framtänderna. Dess form är nistan oval, och det har a äldre exemplar lang's sutura sagittalis en crista. Timninglonen äro af vanlig storlek. Interparictalbenet förändrar formen efter åldern. Hos äldre exemplar är det framait spetsigare. Det är i allmünhet subtriangulärt. De yttre hörselöppningarne äro tubformade och framstiende. Pannan är smal och utan processus postorbitales, churu spår till desamma förefimnas. Kindbågarne äro mycket starka, och mest utstáende baktill, derigenom att processus zygomatici it timningbenen stå nästan rä̈t ut, och äro linga, dì deremot processus zygomatici â öfverküken stå utåt och bakàt samt bilda en spetsig vinkel mot cranicts longitudinella axel. Okbenen äro mycket breda, och uppsända en kort process, som begräinsar orbitæ baktill och neltill. Öfrerkikens processus zygomatici äro mycket höga och vertikalt hoptryekta, sant odelade. Foramina infraorbitalia, som äro helt sma och vertikala, hafva sitt lïge framom basen af nümnde processer, och deras yttre vägg. bildar en utstaende kanť. En liten del af tirbenen synes mellan öfre ändan af okbenen och pambenen. Nackbenets basilardel har ai undre sidan en djup grop. Fossa pte-

1) A Universitetets i Lund Zool. muscum hafva vi sett ett subfossilt benhufvud, funnet i en torfmosse i Skine, hrars längd är $6 \frac{1}{4}$, och bredd öfver okbenen baktill $4 \frac{1}{4}$ '. 
rygoideæ äro djupa, och lamina interna har en lâng lamulus pterygoideus, som med sin nedät böjda spets liagger sig intill bulla ossea. Tandraderna divergera starkt hakit. Gombenen äro sulbtriangulära, med en liten spets i bakre kanten, och foramina palatina üro belägne rid sidone af deras främsta spets. - Foramina incisira ligga nistan helt och hallet i mellankäksbenen. Täshenen räcka längre tillbaka än mellankäksbenen. Underk kens angularprocess är stor. med afrundad spets, och utgair från underkakens undre sida. Processus coronoideus är högre än condyloideus. Benhufvudets form tyckes förete den mesta öfverensstïnmelsen med den af Arctomys, nïr man undantager dennes processus postorbitales, och den nagot starkare brggnaden af Bifverns hufvud. - Hvad skelettlyggnaden für üright betriftlar, sí ïfrerensstimmer den med lufvudet uti strrka och groflek: de frimre extremiteterna äro spensligare an de bakre. Sranstertebrorna ha stora sidoprocesser. Acromion ïr bred, och har icke i sin bakre kant naigon vinkel eller process. Öfverambenet är kort, och har sin nedre inda bred. Spina tubereuli majoris bildar en utstaende process 'processus deltoileus/. Fossa anconara ir ej genomborrad. Underarmbenen äro rörliga, men capitulum radii är oralt och ej rundt. Claricula är stark. Benen i carpus äro 9 (ehuru os naviculare och os lunatum iro sammanruxue) derigenom, att os multangulum minus ar deladt i 2:ne, och att pi inre sidan af carpus är ett öfrertaligt, nagot aflingt och plattalt ben. Os femoris har en trochanter 3:tins ungefir rid midten af yttre sidan. Tibia är vid sin öfre innla staikt baigböjd, si att dess frimre kontur, betraktad fràn sidan, är konvex. Fibula ar stark, med en nedat riktad process vid öfre ändan och yttre sidan, och nedtill, ehuru sent, sammansmilt med tiljia, duck med distinkt malleolus extermus. Tarsen har 9 beu. derigenom att os scaphoidem är deladt i 2:ne, och den har a inre sidan ett öfvertaligt, plattralt ben.

Blott ett slïgte, Castor, Linxé, tillhör denna familj. BRANDT anmärker, att detta namn hos äldre fürfattare samolikt hirleder sig frin en i folkspraket uppliommen förvexling mellan Bifvern och Josehusijuret (Moschus moschiferus; hvilket af Hinduerna kallas Kinsturi, en förrexling som skulle lafra sin upprimnelse uti det likartade officinella bruket af bada dessa djur. Samme Fürfattare har yttrat den isigten ${ }^{1}$ ), att den Gamla Verldens Bifver ar en frân $\mathrm{X}$. Amerikas skild art, elıuru han icke dem emellan kumnat finna nảgra andra skiljalitigheter, in de, som deras benhufvud fürete. Han kallar den fürre Castor fiber curoparus, och den sednare Custor umericanus, F. Curier. Skiljaktigheterna besti luffuldsakligen deri: att den förre har en kortare och bredare pauna, sa att demnas minsta bredd mellan urbite är betrdligt större än afstandet mellan den frimre spetsen af hjessbenen, vid balire och öfre grïnsen för orbitse, och den knölformiga spetsen af paunbenen vil frimre kanten a orbita, då dessa dimensioner deremot äro ungefär lika hos den senare;

att den förre har en längre nos, och längre näsben, som stricka sig mer eller mindre lingt bakom mellankäksbenen, da de deremot hos den sednare ha sin spets ungefir i samma tvärlinia, som mellankïssbenen;

att den främre näsöppningen hos den förre är subtriangulär, och hos den sednare subrectangulär;

1) Beiträge zur näheren Kenntniss der Gattung Castor; Mem. mathẻm. phys. \& naturelles, de l'Acad. Imp. des Sc. de S:t Pétersb. 'T. VII, 1855, p. 63. 
att foramina incisiva los den förre äro stürre, samt strücka sig något längre tillbaka; och att gropen a undre sidan af nackbenets basilardel hos den förre är nästan rund, och hos den sednare oval. - En del af dessa skiljaktigheter äro ej mycket märkbara hos yngre individer.

Då vi hafva sett, att stundom å vissa localer racer kunnat utbilda sig, som förete märkbara afvikelser i benhufudets byggnad fran den stam, hvarifrín de pâtagligen härstamma, sî kumma vi dock svirligen tillerkinna dessa skiljaktigheter nigot annat virde in det af race-skillnader. Exempel derpá lemnar oss Spetsbergs-Renen, enligt den af ANDERSÉN gjorda framstillningen af jemförelsen mellan den och den Lappländska samit den Grönlïndska $\left.{ }^{2}\right)$.

\section{Fam. SCIURID $\AA$, WATERHOUSE.}

Denna familj utgör den 2:dra stora gruppen af gnagarne, d. v. s. de Sciuromorpha, enligt BRANDT. De hafia underbenets bala ben skilda, och fibula saledes fullstindig, samt skilja sig frim de andra, som hafia underbenet bildadt pa samma siitt, derigenom att de hafva processus postorbitales, samt odelade processus zygomatici a offerkäken. Sligtena Tamias och Anomalums göra undantag hirifrin, derigenom att Processus Zygomatici a överkiken iro genomborrate, och siledes delade af foramina infraorbitalia: dessa üro serdeles sma lios det förra, men stura hos det sednare sligtet. Detta gör affen undantag derigenom att det saknar processus postorbitales, eller har dem rudimentïra. Pteromys (Sciuropterus) gör stundom undantag derigenom att tibia och fibula nedtill äro sammansmälta.

De hafva fullstindiga nyckelben, och underarmens ben äro rörliga. Öfverarmbenet. har vid nedre indan ett hal ofvan condylus internus, stundom afven i fossa anconza, och lårbenet har en trochanter 3:tius närmare dess öfre ända. Craniet utmärker sig för öfrigt genom i allmänhet oral form, genom en bred panna, som alls icke är hopknipen mellan orbits; och pannbenen äro linga, men nosen ir kort och med fullstindigt förbenade sidoviiggar. Suturen omkring interparietalbenet försimer tidigt. Fosse pterygoidece temligen grunda. Foramina infraorbitalia små, nära gomkanten, och straxt framom den 1.sta kindtandens alveol. ¿ underkaken äro angular- och coronoïdprocesserna räl utbildade, och den sednare utgar fran underkitiens undre sida. Kindtinderna $\frac{5}{4}$ eller $\frac{4}{4} \frac{4}{4}$, med fullstindiga rötter.

Man anser $\mathrm{i}$ allminhhet de till demna familj hörande gnagarne för att vara de högst utbildade af alla, och brukar derföre vanligen att ställa dem i spetsen för ordningen. I öfverensstimmelse med de grunder, som vi följt vid uppstillningen af familjema, enligt den ofvan lemnade synoptiska tablin, miste vi, sissom vi redan yttrat, anse, att Sciuriderna mindre än de Myomorpha gnagarne uttrycka det typiska elementet för denna orduing, och att de genom underbenets byggnad, och genom den breda pannan å craniet risa en märkbar tendens till de Hystrichomorpha gnagarne, och följaktligen böra intaga en plats mellan de

1) Öfrersigt af Kongl. Wetensk. Akad-s Förh. 1862, p. 457. 
Myomorplıa och dessa sednare. Vi anse, att Haploodontiderna utgöra en öfvergångsform mellan de Sciuromorpha och de Hystrichomorpha gnagarue. Äfren sliigtet Anomalurus bildar en sådan öfvergång.

Näst Muridfamiljen ür denna den artrikaste, med omkring 150-160 arter, från alla rerldsdelar, med undantag af Australien. Dessa fördelas pá 8 slïgten, enligt den hïr bifogade synoptiska tablain.

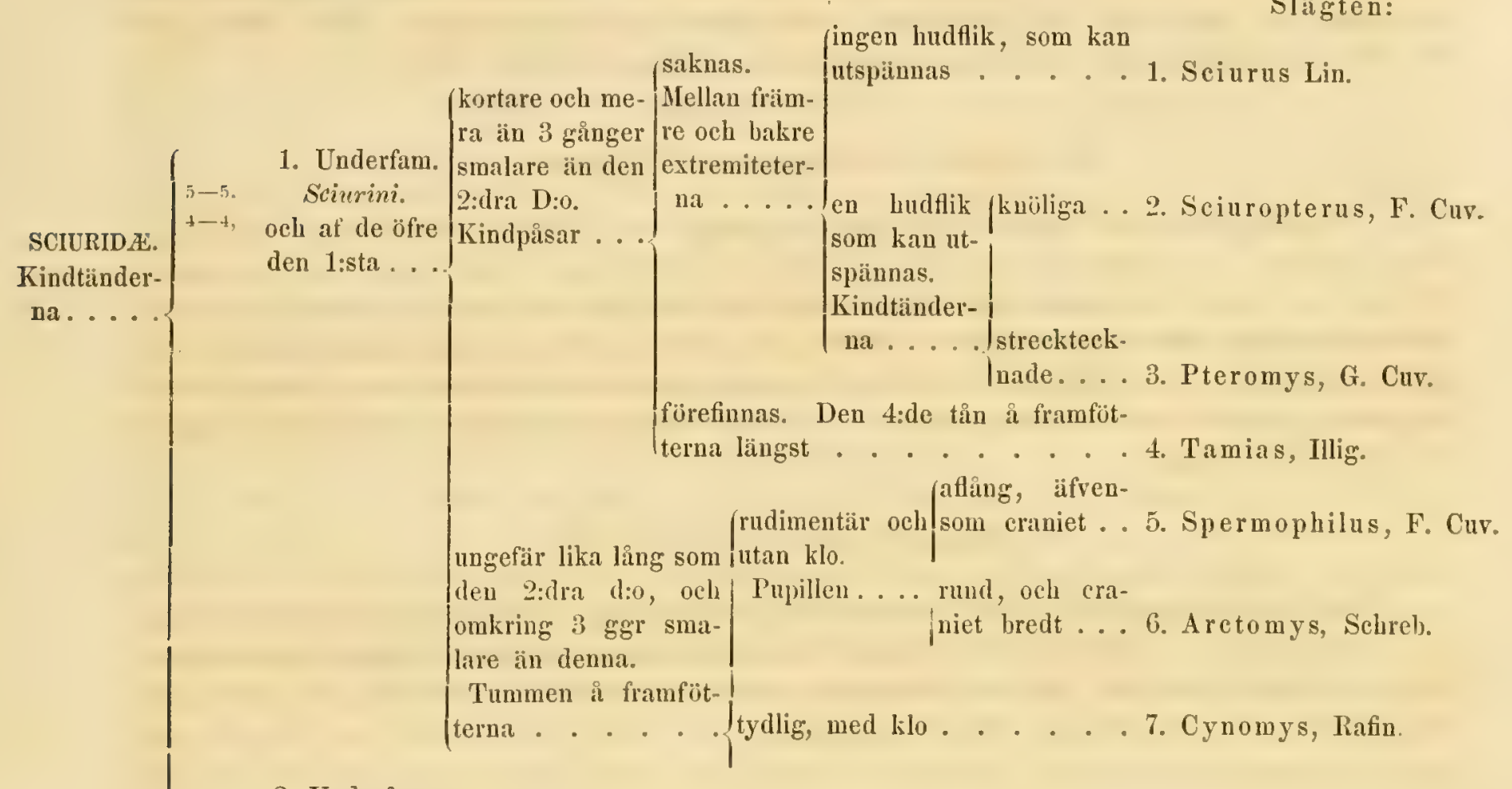

2. Underfam.

$\frac{4-4}{4-4}$

Anomalurini.

1. Underfam. Sciurini, Buduenb.

Kindtändernas antal $\frac{5-5}{4-4}$, men den främsta af de öfre är mycket mindre ïn de andra, och hos minga Nordamerikanska arter är den, enligt BAIRD ${ }^{1}$ ) tidigt atfillande, sal att de dia endast hafva $\frac{4-4}{4-4}$ kindtänder. Alla ha tydliga processus postorbitales ${ }^{2}$ ).

\section{Slägtet Sciurus, LinNÉ.}

Framtänderna hoptryckta. Kindtänderna knöliga,den fräimsta i öfverkäken mycket liten, kortare än den 2:dra D:0, samt mera än 3 gånger smalare än denna. Öfverlïppen

1) L. c. p. 241 .

$\left.{ }^{2}\right)$ Man har stundom uppställt underfum. Sciurini för de 4 första slägtena, och underfam. Arctomyini, für de 3:ne derpi följande. 
klufven. Kindpasar saknas. Öronen mer eller mindre linga. Tummen á framfötterna rudimentär och utan fullstandig klo. Svansen ling, linghairig, med de längsta håren ì sidorna. Benhufrudet kort; ljernkapseln bred och kullrig, med mycket kort, eller ingen crista sagittalis. Panubenen äro mycket breda, och processus portorbitales böjda nedàt och bakait. Okbenen temligen smala och föga utstiende. Nisbenen ga ej sa langt tillbaka, som mellankäksbenen. - 3:dje och 4:de kindtänderna ofvan, och de 3 bakersta nedan subquadrangulära; 2:dra och 5:te ofvan, och den första nedan subtriangulära i kronan. — 90-100 arter frin alla verldsdelar, med undantag af Australien. (Sciurus vulgaris, Lin.).

\section{Sligtet Sciuropterus, F. Cuvier.}

Frantänderna icke loptryckta, utan trekantiga, med konvex frimre sida. Kindtanderna knöliga. En luultik a sidorne af kroppen mellan frimre och bakre extremiteterna, och som är fistad vid dessa, samt med tillhjelp af dem och ett langt och smalt benartadt eller broskartadt bihang vid carpus (en förlingning af os pisiforme) kan utspaimas och begagnas sasom en slag's fallskïrm. Uha och radius stundom nedtill hopwuxna, liksom tibia och fibula. Eljest likna de föreg. Slägte. - 17-18 arter från Europa, Asien och N. Amerika ( $S c$. volans (Lin.)).

\section{Slïgtet Pteromys, G. Covier.}

Kindtänderna strecktecknade. Processus postorbitales mycket stora, och pamnan mellan orbitæ konkav. Sransen jemnhairig rundtom, icke tvåsidigt hàrig. Liknar cljest föregaiende slägte, utom det att de hithörande arterna äro större. - Omkring 10 arter frin södra Asien och dess öar (Pt. petaurista, Pall.).

\section{Slägtet Tamias, Illiger.}

Stora kindpåsar som sträcka sig till nacken. 4:de tån å framfötterna längst, och tummen rudimentir. De permanenta kindtimberna endast $\stackrel{4-4}{4-4}$, emedan den 1:sta är affallande, och deras kronor knöliga. Kindtandraderna divergera framait. Öfrerkïkens processus zygomatici äro genomborrade af ett litet naistan rundt foramen infraorbitale. Craniet är mera nedtryckt än hos Sciumes, och kindbigarne äro näistan räita. Det liknar eljest i det närmaste det af denne sednare. Färgteckningen är utmärkt genom mörka och ljusa lingsgaiende band på ryggen. - 4-5 arter frân Europa, Asien och N. Amerika, en af dessa (T. striatus (Lin.)) gemensam för alla tre verldsdelarne ${ }^{1}$ ). De starkt utbildade klorna antyda deras förmága att griifva.

( ${ }^{1}$ Enligt A. J. Retzius. Fauna Svecica, och S. Nilsson, Skand. Fauna, Däggdj. 1:sta uppl., har denna art en gâng, i slutet af föra seklet, blifvit skjuten i Dalarne, ock detta exemplar skïnkt till Kongl. Wetensliaps-Akademien i Stockholm af Assessor Blom. Sedan har den icke hos oss blifvit funnen, men förekommer i norra Ryssland. 


\section{Slägtet Spermophilus, F. Cuvier.}

Stora kindpasar. 1:sta Kindtanden $\mathrm{i}$ öfverkiken ungefür lika lang, som den 2:dra d:0, och ungefär 2-3 gänger smalare än denna, samt icke affillande. Kindtandraderna naigot böjda, men lika langt skilda fram-och baktill. Öronen af omvexlande storlek. Pupillen afling. Craniet ungefür sädant, som hos Sciurus, icke nedtryckt, stundom med kort crista sagittalis. Omkring 26 arter frản Europa, Asien och N. Amerika. Man har uppställt dem uti 2:ne subgenera.

\section{Subgen. Colobotis, Brandt.}

1:sta kindtanden ofvan omkring 2 gånger smalare ån den andra d:0, med 3 eller 4 mer eller mindre tydliga flikar, hoptryckt och transversell. Oronen mycket små, med afhuggen eller nästan afhnggen spets; etc. (Sperm. citillus (Pall.))

2. Subgen. Otospermophilus, Brandr.

1:sta kindtanden ofvan ungefär 3 gånger smalare än den 2:dra, konisk, tillspetsad, och med en liten bugt $\mathrm{i}$ inre kanten. Öronen af medelmåttig storlek, ungefär lika med $1 / 3$ af hufrudets längd. - Endast från N. Amerika (Sperm. Beecheyi (Richardson)).

\section{Slägtet Aretomys, ScHreber.}

Små eller inga kindpåsar. Pupillen rund. Öronen mycket små. Tummen rudimentär, med ofullständig klo. Framtändema föga hoptryckta. 1:sta kindtanden i öfverkäken icke affallande, ungefür hälften mindre än den 2:dra d:o, och lika ling som den, med halfcirkelformig krona, och med en transversell knöl i yttre kanten. Kindtandraderna ungefür lika langt skilda fram- och baktill. Craniet nâgot nedtryekt, med konkav panna. Processus postorbitales mycket stora. Hjessan med erista sagittalis hos de ädre. — Stora och undersätsiga, med liort svans. - 8 arter från Europa, Asien och N. Amerika, hvaraf 5 frân denna sednare verldsdel (A. marmota (Lin.)).

\section{Slägtet Cynomys, RAFinesque.}

Likna dem af föregående sl., men tummen ¿̊ framfötterna har en fullstindig klo. 1:sta kindtanden ofvan nïstan lika stor, som den 2:dra dito. Kindtandraderna divergera framait. Öronen nảstan rudimentära. - De till detta slägte hörande båda arterua ( $C$. hudovicianus (Ord), och Gunnisonii, Baird) kallas Prairie Dogs, och tillhöra endast N. Amerika. Kroppslängd $12^{\prime \prime}-13^{\prime \prime}$.

\section{Underfam. Anomalurini.}

Kindtänderna frân början $\frac{4-4}{4-4}$, strecktecknade. Öfverkikens processus zygomatici delade genom stora, ovala foramina infraubitalia; och frambenen sakna processus postorbitales, eller la dem rudimentira. En ludflik pai sidorne af kroppen mellan frimre och balkre ex- 
tremiteterna, liksom hos Sciuropterus och Pteromys, till hwars utspinnande ett langt broskartadt eller tendinöst bihang vid olecranon är behjelpligt. — Ett slägte:

\section{A nomalurus, Waterhouse.}

Sransen som är ling, har ¿ undre sidan mot basen en rad kölade och med en tagg försedila, alternerande och stora hornartade fjall. Underarmen och handen äro ej fistade vid hudfliken i kroppssidorna. Refbenens antal ï 15 par (Temminck ${ }^{1}$ )). - 4 arter frin vestra delarne af mellersta Afrika (Sierra Leona och Fernando Po). De tyckas i Afrika vara vicarierande former för de flygande ekorrarne, som der icke förekomma. (Anomal. Fraserii, Waterhouse). ${ }^{2}$ ) Detta sligte stir pả öfergaingen till de Hystrichomorpha gnagarne, hvilken grupp vi börja med följande familj.

\section{Fam. HAPLOODONTIDE.}

Fibula fri och fullständig (Peters), och sannolikt äfven clavicula. Kindtänderna äro $\frac{5-5}{4-1}$, prismatiska, och med ofullständiga och öppna rötter, och den första i öfrerkíken mycket liten, liksom hos Sciurus: men deras kronor aro ej linöliga, utan dentinen kommer der i dagen, omsluten endast pa sidurne af en enkel emaljslynga, som a yttre sidan bildar en utstiende kant. Benhutindets form är serdeles egen. Sedt of anifran är det triangulärt, nackbenet bildande triangehs bas, hrilken är mer an hälften sa lang, som dess sidor. Dessa bildas till större delen af de linga, snedt framifiản bakat utstiende kindbagarne. Det in mycket nedtryckt, med ofre och undre sidorne nistan parallela. Atistandet mellan den bakie andan af okbenet och den yttre tubformade hörselöppningen ar helt litet, och sjelfva hjerukapseh ir saledes bred och kort; den saknar crista sagittalis. Pannan är mycket smal, utan spår till processus postorbitales, något konkar framtill, och de förenade ögou- och tinninggroparne äro mycket stora. Nosen är kort och trind. Benhufundets största bredd öfver den bakre delen af kindbågarne imnehalles ungefïr $1 \frac{1}{3}$ ganger i dess längd, eller utgiir ej fullt $\frac{3}{4}$ af dema. Okhenet ar spenslight och föga büjlt. Foramina infrarbitalia, som genomborla öfverkakens okbensntskott, ïro af medelmattig storlek, wala, samt riktade snedt uplat. Foranina incisiva temligen stora, och belighna nïra fiamtäntema. Den bakre n isöpmingen belägen bakom de bakersta kindtänderna. Fossa pterygoidere grunda. Bullæ ossex små, men de yttre lörselöppuingarne stora. C'nderkäken är knt; angularprocessen är stor och horisontelt utbredd, samt ufgatende från underkäkens undre sida. Processus coronoideus är högre äll condyloüdprocessen, stor och ned bakat böjd, rundad spets 3). - Framfötternas klor bildade för grafning, och större än de bakres. - Blott

1) Esquisses Zoologiques sur la côte de Guiné, Mammiféres, p. $144 \& 145$.

2) Af Anomal. laniger T'emm. förefinnes å Universitetets wuseum härstädes ett exemplar, hemfördt från Sierra Leona af framl. Professor Adam Afzelius. Arten beskrefs af Temminck först 1853, 1. c.

$\left.{ }^{3}\right)$ Benhufvudets form tyckes, tillfölje af den mellan orbitæe inknipna pannan, mera tendera at de Myomorpha äu de Sciuromorpha gnagarne, och denna form i förening ned underbenets byggnad tyckes güra den fortjent af att bilda en egen familj. 


\section{Slägtet Haploodon, Richardson; Brandr. (Aplodontia, Richardson.)}

Öronen medelmâttiga, uppstiende ur fällen. Nosen sídan som hos Sciurus. .Tummen ¿ framfötterna med fullstïndig klo. Sransen nästan rudimentair. Fotsulorne nakna. - Enligt Batrd och Peters ${ }^{1}$ ) sannolikt 2:ne arter, $\boldsymbol{H}$. leporinus, Richardson, och $\boldsymbol{H}$. califurnicus, Peters, från vestra delame af Förenta Staterna. Den förra arten är 13" -15" láng. Lefver i hailor i jorden.

\section{Fam. CHINCHILLid E, Bennett.}

Denna familj, den 2:dra af de Hystrichomorpha gnagarne, stír nüra den föjjande, och skiljes från den nästan endast genom kindtändernas byggnad. Af WATERHotse blef den uti ett seduare arbete ${ }^{2}$ ) uppstäld sâsom underfamilj under familjen Irystricide. Af WaGser och BrandT blef den upptagen salsom en egen familj, och af aktning för dessa secinare auktoriteter anse vi oss böra göra detsamma, ehuru vi äro öfvertygade, att kindtindernas form icke i och för sig ensam är tillräeklig att grunda en familj ${ }^{3}$ ), och ehuru vi nogsamt fimna, att den för öfrigt icke visar nigra serdeles betydande skiljaktigheter frïn den füljande familjen. Dock füreter den egna tandformen och en del andra karakterer, en märkliar tendens till de Lagomorpha gnagarne, och detta synes lemna ett vigtigt skäl att här tillerkämna tandbildningen ett större värde, än den eljest förtjenar, med afseende pả begränsningen af större grupper.

Kindtünderna $\frac{4-4}{4-4}$, med ofullständiga rötter, och bildade af 2 eller 3 transversella och parallela, eller nästan parallela, af emalj omslutna lameller, och de förete mycken likhet med hararnes, med undantag deraf, att de arro större och tandraderna saledes längre. Clavicula är fullständig, och fibula är skild fràn tibia, men bàde claricula och fibula äro spensliga och svaga. Processus zygomatici å öfverkäken äro delade, och den öfre, mindre grenen ïr horisontelt plattad, och den nedre vertikalt hoptryckt. Foramina infraorbitalia äro serdeles stora, nästan njurformiga, högre än breda. Benhufvudets byggnad eriurar bade om Hystricider och Leporider. Det är mer eller mindre langsträckt, med smal och temligen hög nos, hvars sidoväggar äro fullständigt fürbenade och täta. Näsbenen äro följaktligen smala. HJjernkapseln är mer eller mindre bred och kullrig, och fossae temporales derföre obetydliga eller inga. Pammbenen äro temligen breda, ehuru supraorbitalkanterna äro utringade. Spar till processus postorlitales förefinnas. Foramen magnum ar stort, och nackbenets basilardel ar lang och smal. Corpus ossis sphenoidei är smal. Fossa pterygoideæ äro öppma utåt och hamuli pterygoidei äro fästade vid bullae ossex. Bullae ossta äro stora, orch yttre hörselüppningen är vid, och saknar tub. Okbenet, som ïr starkt, och kort, har vid sin bakre ända en kort process. Det har äfven en saidan å bakre delen af sin öfre kant, midtemot den ru-

1) Monatsber. d. Kön. Prenss, Akod. d. Wiss. zu Berlin, 1864, (1865) p. 177.

2) Natural History of the Hammalia, Vol. II, p. 207.

3) Härpå hafva vi exempel uti slägtena Castor oelı Nyopotamus, som, om man ensidigt hölle sigg till tänderna, skulle blifva sammanförda uti en familj, eluru de för öfrigt förete väsendeliga skiljaktigheter. 
dimentira processus postorbitalis. Båda dessa sedhare bilda den bakre gränsen för den stora orbita. Gomhralfvet är smalt och litet, derigenom att gombencn baktill äro starkt utringade, så att den bakre näsöppningen sträcker sigg framom de bada bakersta kindtänderna. Kindtandraderua divergera bakait. Foramina incisiva äro stora, sträickande sig ända till grannskapet af de främsta kindtanderna, och belägne bide i mellankäks- och kiakhenesu. De äro atskilde genom en icke helt och hillet förbenad mellanvägg. 'T'irbencn äro sina, belägne mellan den frimre uppstigande grenen af okbenet och pambenet, och begränsas frantill af den öfe grenen af öferkäkens okbensutskott. Tnderkäken har den för de Hystrichomorpha gnagarne utmärkande formen. Angularprocessen är stor och ling, mer eller mindre tillspetsad, samt utgìende frán yttre sidan af alveolardelen. Coronoülprocessen är liten, men condyloüdprocessen är lang. Skelettet företer för öfrigt en del karakterer, som visa tendens at hararnes. Lindvertebrorne, 6 till antalet, ha samma form, som hos harane, med undantag deraf, att de bakre taggutskott'n äro linga och starkt riktade framat, och de bakre längre sidoutskotten äro riktade äfvenledes framat och snedt utat och nedat. Scapula har en lång acromion, som lar en bakre process vid spetsen. Clavicula är mycket smal. Öfverarmen har en liten deltoïdprocess. Underarmens ben, som äro smala, äro hoploddade (åtminstone hos Chinchilla). Apertura pelvis bred, men liog. De bakre extremiteterna mycket större och lägre än de främre. Os femoris rakt och jemntjockt, har trochanter 3:tius, sittande högt uppe pa yttre sidan af trochanter major, som är uppstaende högt öfver caput. Fibula är serdeles smal, nedtill förenad med tibia, men dock fullstindig. (Enligt skelett af Chinchilla.). Öron och ögon stora. Svansen mer eller mindre lang, atminstone mot spetsen lingharig. De bakre extreniteterna längre, än de främre. - Nigra fii gnagare frin S. Amerika, med en serdeles fin harbeklädnad. De ha något kaninartadt uti sitt utseende, och lefva i hálor i jorden eller mellan klippor. Vi uppstailla de 3:ne hithörande slägtena pă följande sätt:

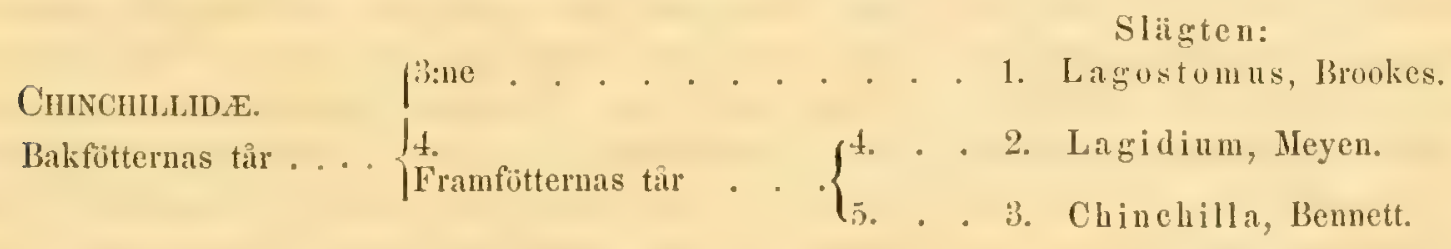

1. Slägtet Lagostomus, Broores.

Framfötterna med 4, och bakfötterna med 3 tair. Sransen med kortare hår mot basen. Alla kindtänderna hafva 2:ne lameller, med undantag af den bakersta i öfverkäken, som har 3:ne sidana. Öronen och svansen medelmâttiga. - Bullse ossea icke serdeles stora, och tinningbenen (egentligen de ben, som HuXLEY ${ }^{2}$ kallar ossa prootica) sträcka sig icke upp pi̊ öfre sidan af craniet, utan äro af vanlig storlek. Nackbenet och hjessbenen bilda en gemensam erista lambdoidea, eller nackekam. Kindtandradernas divergens serdeles stark. Foramina incisira temligen korta, och långt skilda frăn framtainderua. - 1 art, L. trichodacty-

1) The Elements of Comparative Anatomy, p. 153. 
lus, Brookes, eller den sia kallade Wisacha, från Pampas i Paraguay och Buenos-Ayres änta till Patagonien. Den är omkring 20" lång.

\section{Slägtet Lagidium, MEYEN.}

Fram- och bakfötter med 4 tår. Alla kindtänderna med 3:ne lameller, med undantag af den 1:sta i underkäken, som har $2^{1 / 3}$ d:o. Öronen mycket långa och smala, liknande hararnes, och de $\mathrm{i}$ förening med den korta nosen gifva hufvudet en stor likhet med dessas. Svansen lang och lingharig. Klorna sma. - Benhufvudet liknar mycket det af föregâende slägte. Timminglnenen äro af' vanlig storlek. De rudimentaira postorbitalprocesserna ganska tydliga. Foramina incisiva äro störe, sant hafva ett mindre foramen framom sig. Underkäkens angularprocess är trubbig. — Ett par arter från Peru's och Chili's bergstrakter. (L. Cuvieri, Bennett, frin Perus högslätter, 12000-13000 fot öfver hafvet. Stor, som en kanin).

\section{Slägtet Chinchilla, Bennetr. \\ (Eriomys, Lichtenstein.)}

Framfötterna med 5, och bakfötterna med 4 tår, tummen å de förra, och den 4:de tỉn a de sednare mycket korta, men dock med fullständiga phalanger. Klorma korta, och sransen temligen lang och langharig. Iabfälen ytterst fin. Kinltänderna lika dem af föregatende slägte; men benhufvulet är mycket afvikande. De periotiska (HUXLEY) benen serdelesstora, och bulla ussea hafia sin bakre del utstaende lika langt tillbaka, som nackbenets temligen lı̈ga crista externa. Ossa prootica (HuxLey), som ofvantill begränsa ossa tympanica, upptaga en del af hjernkapselns öfre sida, och äro der nagot uppståcnde öfver hjessbenen, men stöta ej intill lwarandra, utan lemna plats för os interparietale sig emellan. Detta sednare bens suturer försvima dock tidigt. Bullae ossege äro mycket utstitende pa craniets undre sida. Pannan är langsat konkaverad. Nosen har a hrardera sidan en temligen djup och stor grop. Foramina incisiva lika med föregaende. Underkäkens angularproeess spetsig, med nagot uppåt böjd spets. Costa spensliga, 13 par. - 2:ne arter (Ch. lanigera, Bennett, och brevicaudata, Waterhouse) frin Perus, Chilis och Bolivias Cordillerer, 8000-11000' öfver hafvet. Den förra äl omkring $10^{\prime \prime}$, och den seduare $14^{\prime \prime}$ lang.

\section{Familjen SPALACOPODID E, BRANDT.}

Hystrichomorpha gnagare, med fullständiga nyckelben och vadben, och genom stora foramina infraorbitalia delade okbensutskott a ofverkiken, och hrilkas kindtainder, till antalet merendels $\frac{4-4}{4-4}$, hos ett slighte $\frac{3-3}{3-3}$, icke äro afdelade i parallela lameller, utan blott med mer eller mindre djupt ingiende bugter af emaljen. Med undantag af ett par slïgten, Ctenodactylus och Pectinator, är den öfre grenen af öfverkäkens okbensutskott vertikalt hoptryckt, eller har genomskärningens vertikala diameter störst. 


\section{Slagten:}

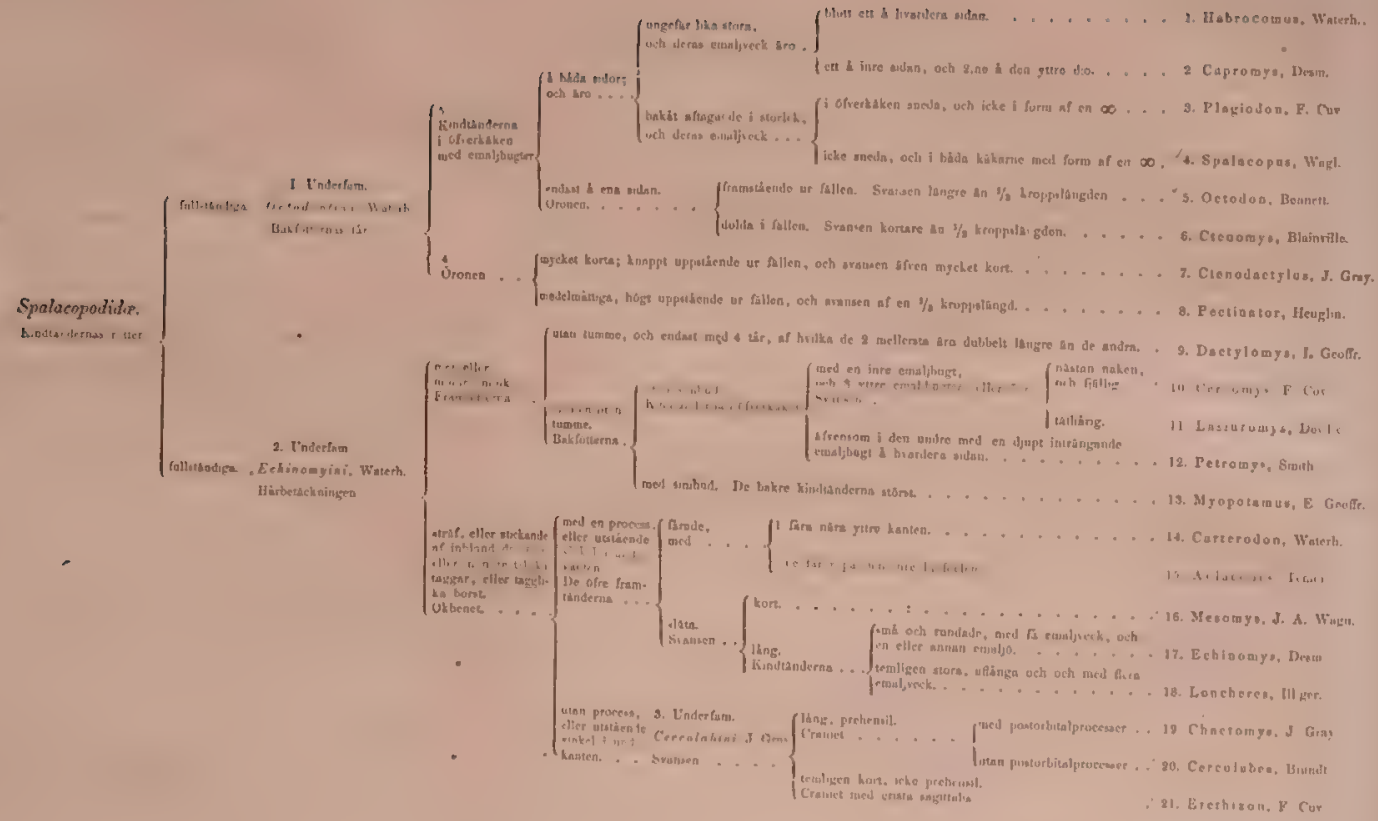



(Huxley). Pambenen äro mycket breda, och ha tydliga postorbitalprocesser. Okbenen airo stora, och ha en process i undre kanten baktill. Underkäken har en liten coronoïdprocess. Öronen af medelmaittig storlek. Tummen ^̊ framfötterna rudimentär, och dessa ha 4 , och bakfötterna 5 fullstindiga tår. Kroppen undersätsig, och svansen medelmaittig, gleshårig. 3:ne arter frain Cuba och Domingo. (C. pilovides, (Say); nära 13"laing). De klättra med stor skicklighet.

\section{Slägtet Plagiodon, F. Cuvier. \\ (Plagiodontia, F. Cuv.)}

Kindtănderna aftaga något $\mathrm{i}$ storlek bakât, de $\mathrm{i}$ öfverkäken hafva ett djupt ingâende emaljveck a yttre, och ett d:0 i inre sidan, och dessa veck sta snedt framifrin bakait, och alternera. Kindtänderna i underkiaken likna dem af föregäende slägte. Okbenen sakua process i undre kanten. - 5 tår i alla fötterna. Öronen smá; svansen kort, naken och fjällig. 1 art, $P l$. aedium, F. Cuvier, från St. Domingo.

\section{Slägtet Spalacopus, WAGLER ${ }^{1}$ ).}

Kindtänderna aftaga i storlek bakit, och hafva ett ingiende emaljveck i hrardera sidan, och kronan med form af en liggrande 8, emedan emaljvecken äro hrarandra motsatta, och detta i baida kikarne. Okbenen hafra en utstaende vinkel i undre kanten baktill. Nosen trubbig. Öronen små eller medelmâttiga. Ögonen medelmåttiga. Framfötternas tumme rudimentair, bakfötterna 5-tioiga. Svansen temligen kort. - 2 arter, från Chili och södra Anderna. (Sp. Poeppigii, Wagler. från Chili; 6" laing).

\section{Slägtet Octodon, BennetT.}

Kindtänderna i öfverkïken aftagande i storlek bakat, och med ett grundt emaljveck å inre sidan, och med den yttre sidan konkav, och de i underkäken med ett dylikt reck a hvardera sidan. Craniet med stora bullæ ossce, och ntan process i undre kanten af okbenet, men med en knappt märkbar vinkel derstides. En liten coronoüdprocess förefinnes ä underkäken. - Öronen medelmaittiga, framstíende ur fällen. 5 tir a alla fötterna, men tummen ¿ framfütterna är rudimentär. Svansen längre än lıalfva kroppen, täthairig; neh med längre hår vid spetsen. - 3:ne arter från Andiska Bergen i Peru, Chili och Bolivia. (O. degus, Molina. Kroppsliingden $71 / 4 "$.)

\section{Slägtet Ctenomys, Blainyille.}

Kindtünderna aftagande i storlek bakả, med sneda, halfmánformiga kronor, i öfverkïken med den konvexa kanten inat, och i underkikien triirtom. Den bakersta kindtanden

1) Vi räkna till detta slägte iffen slïgtet Shizodon, Waterhouse. 
helt liten. Öronen dolda i fällen, rudimentära. Ögonen smá. Fötterna med 5 titr, och tummen ¿ framfötterna med klo. Svansen kortare än halfva kroppslängden. — Bullæ ossex a craniet serdeles stora, och sträcka sig längre tillbaka än nackhenet. Okbenen sakna process eller vinkel i undre kanten. - 6 arter frăn Brasilien, Bolivia och södra delarne af S. Amerika till Magellanssundet. (Ct. brasiliensis, Blainv., med kroppsl. 9").

\section{Slägtet Ctenodactylus, J. GraY.}

Anm. På grund af Brands auktoritet ställa vi detta slägte här, ehuru vi icke kunnat finna någon uppgift om beskaffenheten af underbenets ben, och ehuru underkäkens angularprocess icke, sảsom hos de andra Hystrichomorpha gnagarne, utgår från alveolardelens yttre sida, utan frỉn den undre, och slutligen ehuru den icke har flera än 3:ne kindtänder å hvardera sidan, samt nti craniets form visar en stark tendens till Dipodiderna.

Kindtänderna $\frac{3-3}{3-3}$, de öfre med halfmånformig krona, och de undre med en ingåcnde bugt a hrardera sidan. Kindtandraderna nistan parallela. Craniet baktill bredt, med stora bulla osser, och ossa prootica synliga ofvan den yttre tubformade hörselöpningen. Interparietalbenet stort. Pamnbenen räcka icke bakom orbita. Nosen smal, och nïblonens bakre spetsar divergera. Den öfre grenen af öfverkiakens okbensutskott bred och plattad. Foramina infraorbitalia mycket stora, trianguliira och nedtill bredare. Okbenet smalt, utan undre process. Foramina incisiva stora. Underkäkens angularprocess liknar den af de andra af denna familj, ehuru den utgår från den undre sidan af kảken. Coronoïdprocessen saknas, och condylö̈lprocessen ar serdeles kort. - Kroplsformen undersätsig, sorklik. Öronen myeket sma; ögonen medelmattigia. Alla töttema med 4 tilr, och den imersta tan a bakfötterna har a öre sidan naistintill klon en transversell rad af kamformigt staillda hornartade stafvar, och intill dessa en rad styfra hvita borst. Sransen mycket kort med låga borst. — Blott en art, Ct. Massonii, J. Gray, frän norra Afrika, Tripolis. Kroppsl. 5³.".

\section{Slägtet Pectinator, HeugliN.}

Uti Petermann's Geogr. Mittheilungen 1861, pag. 17, och Nova Acta Acad. CresareoLeopold. Carol. 'Tom. XXVIII, an 1861, tab. 2, fig. 1, 5 \& 6, har Heuglix beskrifvit och afbildat ett nytt intressant sliigte, Pectinator, med en ny art $P$. Spekei, Heuglin, som han ställer i märheten af P'etromys, och som blifvit funnen i nordöstra Afrika, i grannskapet af Somalikusten vid 'Teeljura. Benhufvulets och underkikens form, aifiensom formen af kindtånderna, och tårnas antal ( 4 ¿ alla fötterna), allt visar påtagligen, att den har sin riitta plats vid Ctenodactylus, och icke vid Petromys, och detta är sil mycket vigtigare, som det derigenom synes mycket sannolikt, att äfen Ctenodnctylus i början har 4 kindtänder pai hvardera sidan i båda käkarne. Hos Pectinator är nemligen den 1:sta kindtanden, enligt HeugLIN, föga utbildad, och sii liten, att den nästan helt och hallet är dold i tandköttet; och ri hålla det derföre troligt, att den, liksom den främsta kindtanden hos en del arter af Sciurus, ar affallande, och att ett sidant förhillande ar orsaken, hvarföre man hos Ctenoductylus icke 
funnit flera än 3 kindtinder à hvardera sidan, saivida icke en ovarsam praparation dertill varit anledning. Hos Pectinotor hafva de 3 stora öfre kindtinderna halfmánformig krona, med yttre silan konkav, liksom hos Ctenodactylus, men de skilja sig dock frin demas derigenom, att de hafva en liten ingaiende bugt vid inre sidan. De 3 undre kindtänderna skilja sig frain dem af denna sednare derigenom, att de vid inre sidan hafva 2:ne ingaiende emaljbugter i stillet för en. Benhufvudet liknar, enligt Hecguns figurer, fullkomligt det af C'enodactylus, men okbenen äro nigot spensligare. Liksom hos deme sakna de vinkel eller process i undre kanten, och den afviker genom formen af dessa ben sivial som genom formen af benhufrudet $\mathrm{i}$ allmänhet helt och hallet från Petromys. Underkäken saknar coronoïprocess ${ }^{1}$ ). - Nosen temligen spetsig, med hårbevuxet rhinarium. Öronen medelmattiga, högt uppstitende. Sransen at 1/3 kroppslingd, tvisidigt langharig, liksom hos ekorren. Härfällen mycket fin. Kroppslängden omkr. $7^{\prime \prime}$.

\section{Underfamiljen Echin omyini, WATERHouse.}

Kindtändernas rötter fullständiga.

\section{Sliigtet Dactylomus, J. GEOFFroY.}

Hảrbetickningen mjuk, men grof. Kindtinderna nästan lika stora, eller tilltagande i storlek bakăt, de i öferkäken bildade af 2 ne serskilda lober, af hvilka hvarje är inat tillspetsad, och har i yttre sidan ett djupt ingiende emaljveck; af de i undre kiken har den frïmsta 2:ne inre och ett yttre ingiende emaljveck, och de aterstaiende hafva 2:ne lober, af hvilka den bakre ür liten, och den främre ar bredare vid inre sidan, och der har ett djupt ing:iende emaljveck. Benhufvudet har en process i undre kanten af okbenet. Kindtandraderna nistan berörande hvarandra framtill, och divergerande starkt bakit. Öronen myeket små; svansen serdeles làng, naken, fjällig. Framfötterna med blott 4 tar, af hvilka de mellersta äro dubbelt längre ïn de andra. Kroppsformen råttlik. - 2:ne arter från Brasilien och Guyana. (D. typus, Geoffi. Kroppsl. 12".

\section{Slägtet Cercomys, F. Cuvier.}

Framfötterna med en rudimentär tumme. Kindtunderna ungefir lika stora; de iöfverkiken med en djup emaljhugt vid inre sidan, och med 3 emaljöar vid den yttre, hvilka sannolikt vid mindre nötning äro 3:ne ingäende bugter; och de i underkiken liknande dessa, men med omväindt läge för recken och öarne. Svansen li̊ng, nästan naken, och fjällig, lik den af Mus decumanus. Öronen stora. Kroppsformen raitllik. - Benhufvudet har en utsta-

1) Benhufvudet har af Heuglin blifvit i korthet beskrifvet, men icke skelettet för ofright, så att vi om underbenets byggnad hos deme hafva lika liten kinnedom, som om samma ben hos Ctenodactylus. 
ende vinkel å undre kanten af okbenet. - 1 art, C. cunicularius. F. Cuv., från Brasilien. Stor som den större husråttan ${ }^{\mathbf{1}}$ ).

\section{Slïgtet Lasiuromys, Deville $\left.{ }^{2}\right)$.}

Detta slägte kommer mycket nära slägtet Cercomys, och kindtändernas bildning tyckes vara densamma, ehuru de förhandenvarande beskrifningarne visa nágon skillıad. De öfe kindtandraderna äro vid bida andarne något divergerande, och i det nirmaste lika langt aitskilda fram- och baktill. Afstandet å midten är litet, och gomhralfvet siledes smalt. Tandkronorna längre än breda. I öfre käken har hrarje krona ett ingaende emaljveck i inre kanten, och 3:ne i den yttre, af hvilka sednare eft eller annat genom nötningen, isynnerhet pà de bakersta, blifvit förvandlade till oar. I underkiken har hvarje 2:ne inre och ett yttre emaljveck, och den bakersta dessutom en eller ett par öar. - Benhufvudet är, ty vïrr, icke beskrifvet. - Alla fötterna hafia 5 tirr, men tummen i framfötterna är rudimentär. De bakre fötterna betydligt lingre ïn de frimre. Öronen äiro temligen smả, och markbart mindre än hos Cercomys. Svansen är något kortare än kroppen, och täthårig. Hårfảllen är mjuk. Den skiljer sig frain Cercomys genom öron och svans. En art, Las. villosus, Deville, omkring 121/2" lång; fran S:t Paulo i Brasilien.

\section{Slägtet Petromys, SMiri.}

Fötterna med 5 tår, men tummen å framfötterna är rudimentär, och med nagel. Kindtänderna nüstan lika stora och fyrkantiga, sittande snedt, och med ett djupt ingaiende emaljveck a livardera sidan, hvilka veck mötas i midten af tanden. Benhufvudets okben har en utstiende vinkel i mulre kanten. Bullæe ossea stora. Öronen temligen små, hiriga. Mlorrharen langa och talrika. Svansen temligen lảng, täthàig och med lingre hår vid spetsen. 1 art, $P$. typicus, Smith, fri̊n södra Afrika. Kroppsl. $71 / 2 "$.

\section{Slägtet Myopotamus, E. GEoffroy.}

'Tummen í framfütterna xudimentär, med ofullstindig klo. Bakfütterna stora, med simhinnor mellan de 4 inre timn; den yttersta, eller 5:te tan är fri, men har en liten skinnflik lảngs inre sidan. Kindtänderna tilltaga i storlek bakât, och äro nästan fyrkantiga, med 3:ne djupa emaljveck å ena sidan och 1 d:0 å den andra; i öfverkäken äro de 3:me vecken yttre, och $\mathrm{i}$ den undre käken twirtom. Afnötningen fürändrar utseendet något. Benhufrudet är längsträckt, och hjernkayseln äl smal, med en skarp crista sagittalis baktill mellan hjessbenen, äfvensom en hög crista lambdoidea, eller nackekam. Pannbenen med helt små processus

') Sannolikt böra till slägtet Cercomys öfverflyttas de arter, som man brukat upptaga under slägtet Loncheres, ehuru de hafva mjuk bårbeklädnad.

2) Revue \& Magas. de Zoologie, 185̄2, p. 357, tab. XV \& XVI. 
postorbitales. Nosen lâng. Processus paramastoidei å nackbenet serdeles långa. Okbenet stort, med en process i undre kanten baktill. Bulla ossea af vanlig storlek. Kindtandraderna divergera bakåt. Foramina palatina stora, aflinga, och foramina incisiva små. C'nderkäken serdeles stark, med en rudimentär coronoülprocess, och med en starkt utstiende kant i ytte sidan af angularprocessen. - Öronen smả, äfvensom ögonen. Extremiteterna korta. Svansen ling, trind. Spenarne 4 par, belägne högt uppe pî kroppssidorne. - 1 art, M. coypus, Geoffr., 20"_-24" lång; frain de södra delarne af S. Amerika, frán sölra Brasilien till Patagonien, både vester och öster om Andiska Bergen.

\section{Slägtet Carterodon, WATERHouse.}

Framtänderna $\mathrm{i}$ öfverkikken med en fïra å deras främre sida nära yttre kanten, och en långsgaiende rygg à midten, och de undre äro framtill plattade. Kindtinderna i öfrerkäken med ett inre och 2:ne yttre emaljveck, och de i undre käken med lika antal veck, men i motsatt riktning; före afnötningen hafva de tväryggar. Craniet med temligen stora bulla osser, kort nos och ett starkt okben, med en process i mndre kanten baktill. — Hairfillen icke stickande, men med längre tillspetsade, lancettformiga stickelhar eller borst. Nosen trubbig, lairbetackt. Öronen framstiende ur fällen; tummen å framfötterna rudimentär, och tirna vid basen förenade genom hud. Sransen kortare än $\frac{1}{2}$ kroppslängden, med tenligen lång hårbeklädnad, och derunder fjallig. - 1 art, C. sulcidens, Waterh., i början endast funnen fossil; förekommer i Minas Geraes i Brasilien. Kroppsl. 10".

\section{Slïgtet Aulacodes, 'Truminck.}

Äfven detta slägte saknar taggar i hårfüllen, men liar styfva, flata borst, med en fâra a öfre sidan. Framtänderna jemförelsevis större än hos nagon amman gnagare, och de öfre $i$ främre sidan med 3:ne långsgácnde furor uti den inre halfitelen af tänderna. Kindtänderna likna dem af föregäende slïgte med undantag deraf, att den främsta i uuderkäken har i inre sidan 3:ne ingaiende emaljveck. Benhufvudet in starkt, baktill med en kort "rista sagittalis, och en temligen hög nackekau. Bullæ ossea af vaulig storlck. Nosen kort och hög. Pannan bred, med spar till postorbitalprocesser. Okbenet högt, med en utstaende vinkel $\mathrm{i}$ undre kanten baktill. Underkäkens angularprocess temligen kort. - Framfütterna med rudimentär tumme och mycket kort ytterti. Bakfötterna med 3 störe tair, och en rudimentär yttertå. Öronen små och nosen trubbig. Svansen hortare än $\frac{1}{2}$ kroppslängd. 2 arter frîn Afrika (A Suinderiunus, Temm., frän mellersta och södra Afrika. Kroppsl. 20" ).

\section{Slägtet Mesomys, J. A. WAGNER.}

Kindtainderna likna dem af Eckinomys; de öfre med ett djupt inträngande emaljveck i inre sidan, och trenne mindre d:o i den yttre, och aftagande $\mathrm{i}$ storlek bakit. Kroppen 
betäckt med starka taggar. Svansen kortare :in ${ }_{2}^{1}$ kroppslingden. Tummen a framfötterna rudimentär. Kroppsformen liknande den af Cricetus. - 1 art, M. spinosus (Desm.), från Brasilien. Kroppsl 10".

\section{Slägtet Echin o mys, Desmarest.}

(Echimys, Desmarest).

Hårfillen med taggar Framtänderna släta. Kindtänderna små och rundade samt nästan likstora, de $\mathrm{i}$ öfe kïken med ett djupt frìn inre sidan ingående emaljveck, som nästan delar tanden i 2:ne delar, af hvilken den främre är minst, och den bakre omsluter en eller ett par emalj-öar, som sannolikt imnan starkare nötning varit ingående veck, emedan ett sidant reck synes $\mathrm{i}$ denna del i den bakersta tanden ${ }^{1}$ ). De undre likna de öfre, men hafva si̊som vanligt ett omvändt läge för veck och öar. Den främsta undre tanden är dessutom tillspetsad framåt. Kindtandraderna divergera nigot bakăt och äro korta, och den bakre näsöppningen strïcker sig fram mellan de bakersta kindtäuderna. Okbenet med en utstiende vinkel i undre kanten baktill. - Kroppsformen råttlik. Öronen stora och nakna. Svansen glest hårig, med en liten pensel vid spetsen. Tummen ì framfötterna rudimentär, och dessa ha 4, och bakf. 5 fullstäindiga tair. Tarsenna lainga, och den yttersta tån å bakfötterna helt kort, och ännu kortare den innersta. - Omkring 10 arter, förekommande frain de norra delarne af S. Amerika till Paragvay. (E. cayennensis, Desm., stor som Mus rattus).

\section{Släigtet Loncheres, ILLIGEk.}

$$
\text { (Nelomys, Jourdan). }
$$

Liksom närmast föregaiende, hvilka de likna, hafva de en taggig beklädnal, och lång svans, men deras kindłänder äro större, med flera emaljreck. De öfre ha 2:ne hufrudsakliga siolana djupt inträngande transversella veck, som ofta dela tanden i 3:ne lameller, och de i undre käken hafva ett inre och 3 yttre ingiende reck. Craniet har ett starkt okben, med en utstilende vinkel i undre kanten, och med stora bullx ossex, och ling:a processus paranastoidei. - Framfötterna med rudimentär tumme. Öronen korta och tjocka. -8-9 arter fran Brasilien och Guyana. (L. cristatus, Waterh. Kroppsi. 12").

\section{Underfam. Cercolabini, J. E. GraY.}

Okbenen sakna process, eller utstiende vinkel i undre kanten. Näsbenen rïcka längre tillbaka än öfuerkiksbenen. Ios föregitende underfamiljer är det vanligtris motsatsen.

Anm. De till denna underfamilj hörande slägten har man brukat upptaga inom följande familj, och dervid anfört såsom utmärkande karakterer, att de hafva ofullständiga nyckelben, att kroppen är mer

1) Enligt Waterhouse, beskrifning och figurer. 
eller mindre täckt af taggar, och att okbenen sakna process, eller vinkel i undre kanten. Af det ofvanstaende hafva vi erfarit, att stundom slägten, som eljest stå hvarandra så nära, att man någon gång förenat dem i ett enda, (I Ius och Acanthomys) förete den skiljaktigheten uti den yttre kroppsbetäckningen, att det ena har denna mjuk, och det andra har den taggig, och vi knnna således lätt finna, att denna olika beskaffenheten af kroppsbetäckningen ingalunda kan lemna någon duglig karakter för uppstälnningen af en familj; och den kan så mycket mindre användas för att skilja Hystriciderna från Spalacopodiderna, som en del af dessa sednare hafva lika taggig kroppsbetäckning, som somliga af de förra, och dessutom uti dessas taggberäpningen - sådan familjen förut blifvit uppfattad - förefinnas flera olika gradationer. Den karakter, som blifvit hemtad från nyckelbenens ofullständighet, är deremot af vida större vigt, och denna är den enda, som vi anse fullt duggligg för begränsningen af de ifrågavarande bi̊da familjerna; men den tillkomuer långt ifrån alla dem, åt hvilka man tillerkänut densamma. Af de figurer öfver skelettet af Cercolabes prehensilis, som Blainville och Pander och d'Alton lemnat, funno vi, att denne hade fullt utbildade nyekelben, och kommo derföre lätt på den tanken, att dessa hos alla de s. k. klättrande, eller Amerikanska $\mathrm{Hy}$ striciderna äro fullständiga. Efter gjord förfrågan har Professor J. E. GraY i London täckts genom bref underrätta oss, att de skeletter af Chatomys, Sphiggurus (Ceriolabes) och Erethizon, som förvaras i British Museum, ega fullstündiga nyckelben, och att dessa äro starka och väl utbildade både hos Chactomys och Sphiggurus, och isynnerhet hos den förre, men att de äro spensligare hos Erethizon. Således öfverensstämma dessa slägten i detta afseende med Spalacopodiderna. Frånvaron af processen eller vinkeln a undre kanten af okbenen lemnar under sådana förhållanden ingen grund till att skilja dem från den sistnämnda familjen, då äfven andra slägten inom denna, t. ex. Plagiodon, Ctenomys, Ctenodactylus och Pectinator sakna den; men då den är förenad med andra karakterer, bland hvilka vi vilja nämna en starkare utveckling af näsbenen, anse vi dock, att den kan lemna grund till att uppställa de ifrågararande slägtena såsom en egen underfamilj, som tenderar àt den följande familjen Hystricida.

\section{Slägtet Chrtomys, J. Gray}

Sransen lang och prehensil. Kroppsbetickningen taggig, med undulerate taggar, som äro kortare och tjockare pả den främre kroppsdelen; baktill blifia de slutligen borstlika, ifrensom på den undre kroppssidan. Knindtänderna längre än breda, de öre af transversella, grenomgiende emaljveck delade i 3:ne delar eller lober, af hvilka den mellersta är smalast, och de andra 2:ue hafva hvardera ett djupt inträngande emaljveck. Craniet ar kort och tjockt, men pannan föga kullrig. Pambenen med temligen stora postorbitalprocesser. Okbcnen höga, och med en process midtemot postorbitalprocessen. Bullæe ossea stora. Underkikens bada grenar ha en process a undre kanten strax bakom hakvinkeln. _- Öronen små; fötterna med 4 tår, med långa, krökta klor. Svansen fjållig och med glesa hår. -

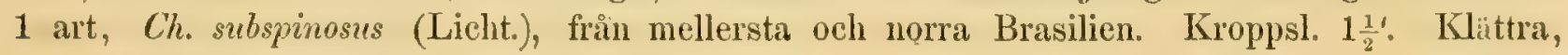
med tillhjelp af sransen.

\section{Slägtet Cercolabes, Brand.}

Kroppen, med undantag af buksidan, mer eller miudre tïckt af taggar, som icke äro undulerade. Pá undre kroppssidan ïro de mer eller mindre borstlika. Svansen lảng och prehensil, och vid spetsen ¿ öfre sidan naken och fjällig; för öfrigt täckt af taggar och borst. Ögon och öron smá; fütterna med 4 tår, med långa krökta och hoptryekta klor; 
innertån, hallux, ¿̊ bakfötterna endast antỵdd genom en knöl. -- Kindtänderna nära lika stora, nästan fyrkantiga, med ett djupt ingảende emaljveck i lvardera sidan, och hvardera af de 2:ne delar, som afiskiljas genom dessa emaljreck, omsluter en transrersell emalj-ö. Craniet kort och tjockt, frỉn sidan betraktadt, stundom nästan rumladt-ovalt. Hjessan saknar crista sagittalis, och pannan process. postorbitales. Pannan och bakre delen af näsbenen äro stundom mycket kullriga. Den öfre grenen af öfverkikens okbensutskott äl verti- kalt hoptryekt, eller med frimre och bakre sidorna hoptryekta. Nosen ir mycket kort. Kindtandraderna divergera bakit. Nisbenen stricka sig mer eller mindre lảngt bakom mellankäksbenen, och äro mer eller mindre breda. Underkäken har en trubbig vinkel i undre kanten i hvardera sidan bakom hakvinkelu, samt en uthragen och mer eller mindre spetsig angularprocess. - Klittra med tillhjelp af svansen. 10-12 arter från S. Amerika och Mexico. (C. prehensilis, (Lin.). Kroppsl. 18").

\section{Slägtet Erethizon, F. Cuv.}

Svansen temligen kort, plattad och icke prehensil. Kroppen betäckt med långt hår, som döljer de langa taggar, hvilka derjemte förefinnas. Franfötterna med 4, och bakfötterna med 5 tar, afven den immersta af dessa sednare fullstiudig. Kroppsformen tjock och undersitsig. Kindtinderna likna $\mathrm{i}$ det nirmaste lem af föreg. sligte, men aftaga i storlek bakit. Efter starkare nötning visa de ingaiende vecken sig stundom såsom emalj-öar. Kindtanraderna divergera temligen starkt bakit. Craniet har hos ïldre en stark crista sagittalis; okbenen mycket utstiende, men baktill spensliga. Den ofre grenen af öferkikens okbens. utskott är vertikalt hoptryckt, d. v. s. har den rertikala diametern störst. Näsbenen stricka sig tillbaka i jemnbredd med orbitx's bakre grins, samt ïro baktill tillspetsade. Underkiken har i hvardera sidan en utstiende vinkel bakom hakvinkeln, en spetsig angularprocess, och en trubbig och låg coronoüdprocess. - 2:ne arter friar N. Amerika. Klattra, och ïta bark. (E. dorsatus (Lin.)). Kroppsl. 2'-3'.

\section{Fam. HYS'TRICID 无, J. GRAY.}

Simplicidentater med ofullständiga, eller inga nyckelben: Fibula är fullständig och skild frim tibia. Kindtänderna $\frac{4-1}{4-1}$, och deras rötter stundom fullstindiga, och stundom ofullstindigar. Öfverkikens okbensutskott delade genom mycket stora foramina infraorbitalia, som nedtill iro bredast och deras öfre gren ïr nedtryckt, eller horisontelt hoptryekt, d. v. s. med yttre och inre sidome hoptryckta, och följaktligen af genomskimingen den longitudiella diametern störst ${ }^{2}$ ). Benhufudet öfverensstammer för öfrigt $\mathrm{i}$ sinal allmänna karakterel med det af föregaiende familj. Blindtarm förefinnes, merendels stor.

2) Äfven denna karakter skiljer Hystriciderna från Cercolabinerna, oclı den vertikalt hoptryckta ofre grenen af ok!ensutskotten förenar de sednare med flertalet af de andre Spolacopodiderna. 
Anm. Waternouse förenade denna familj med de båda föregående, och Brandt delade den deremot i tvenne: Hystrichoïles och Hemionychöldes. Vid betraktandet af den stora öfverensstämmelse i form, som råder mellan Spalacopodide och Hystricide kan man icke undgå att finna, det den förra åsigten har åtskilligt, som talar för sig. Vi anse emellertid, att den betydliga olikheten i nyckelbenens utveckling är en tillräcklig grund till att uppställa de båda grupperna såsom skilda familjer, dâ de ofullständiga, eller bristande nyckelbenen hos Hystriciderna ådagalägga en stark tendens till en del af de Lagonorpha gnagame. Bland de af Brand anförda karakterer, genom hvilka han begränsar fam. Hemionychoides, hafra vi icke kunnat finna nảgon annan, utmärkande dem från Hystriciderna, än den, att de förra hafva den öfre delen af tårbenen mera utbredd, men från denna karakter gör sl. Coelogenys undantag, och den synes oss rara af allt för obetydlig vigt för att ensam kunna tjena till âtskillnad mellan tvenne familjer, och duger på sin höjd endast till att skilja tvenne underfamiljer från hvarandra. Den karakteren, att Hemionychoüdes hafva klöflika klor, tillkommer ingalunda alla, icke sl. Cavia, och äfven den duger icke till famîljekarakter, isynnerhet som vi hos sl. Atherura bland Hystriciderna, Brandt, finna en kloform, som tenderar till den klöflika formen. Pả grund af den olika formen hos tårbenet indela vi emellertîd fam. Hystricida uti 2:ne underfamiljer: Hystricini och Cavini, och uppställa de 9 hithörande slägtena på det sätt, som den här bifogade tablån utvisar.

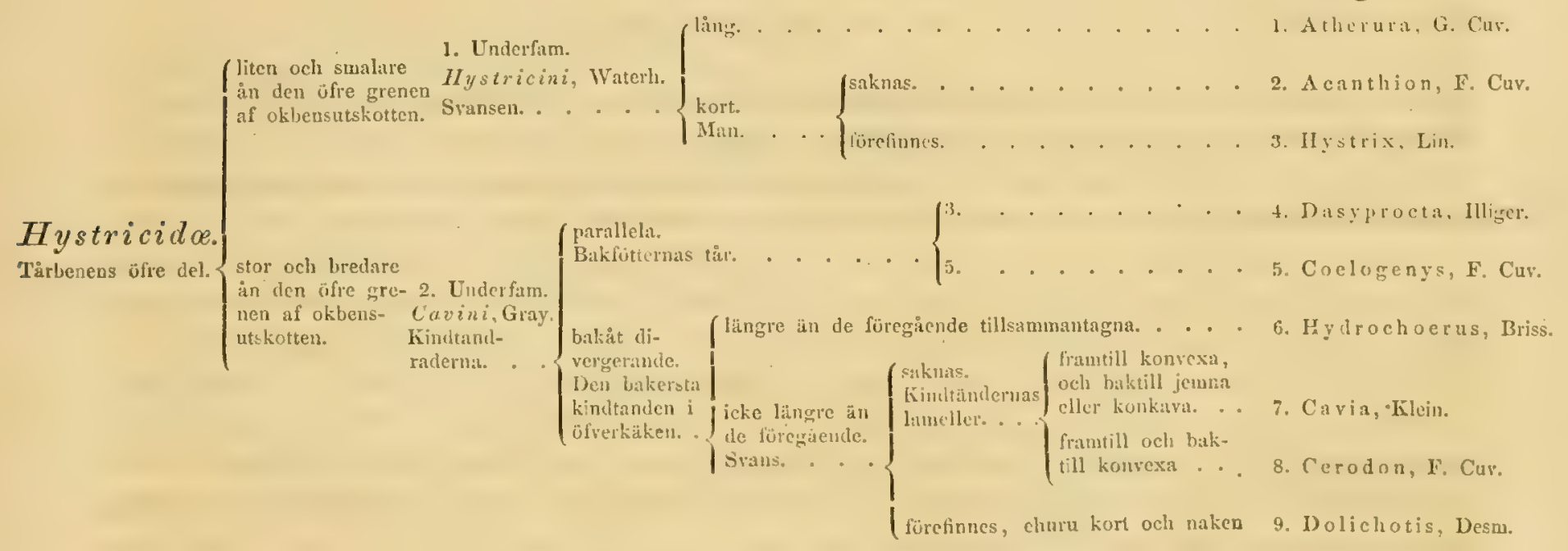

\section{Underfam. Hytricini, Waterholse.}

Tårbenens öfre del liten och smalare än den öfre grenen af okbensutskottet. Kroppen mer eller mindre betäckt af taggrar.

\section{Slägtet Atherura, G. Cuvier.}

Svansen nära sii ling, som kroppen, fjülig, och vid ändan med en quast af borst, som vid spetsen äro formade till hornskifror. Öronen nisstan ovala, hárklädda. Framfütterna med en rudimentiir tunme, och 4 fullstiindiga tirr, och bakfötterna med 5 tîr. Klorna temligen korta, tillspetsade och föga hoptryckta. - Benhufudet med medehuattiga näsben, som äro kortare an pambence, och dessa serhare hafva tydliga postorbitalprocesser. Bullac ossex medelmattiga, och processus paramostoidei korta. Underkikens angulardel bildande en spet- 
sig, föga utstiende vinkel, och coronoïdproc. lig. Ingen vinkel å undre kanten bakom hakvinkeln. Kindtunderna likna dem af Inystrix. Kroppsformen nigot rattlik, och kroppen mer eller mindre tickt af plattade taggar. - Omkring 5 arter frin Asien och Afrika. (A. macrura (Lin.)), 20" laing, sannolikt frïn Sumatra.

\section{Slägtet A canthion, F. Cuvier.}

Svansen kort. Ingen man. Benhufvudet är ofvantill föga kullrigt, och har näsbenen något, men ej mycket längre än pannbenen. Dess form liknar mycket den af Dasyproctu, utom det, att det är något bredare, har mindre tairben, samt trubbigare angularprocess å underkaken, samt icke har nagra postorbitalprocesser. Kroppen luetackt af tagglika borst och taggar, som stundom äro plattade. Eljest likna de dem af följande slïgte. - Ett par aiter från Indien, Nepal, Java, Sunatra och Borneo. (A. javanicus, F. Cuv., 20" lång').

\section{Slägtet Hystrix, LiNné.}

Svansen kort. Man förefinnes. Benhufvudet har den öfre delen kullrig, och näsbenen inycket stora, och betydligt längre än pannbenen "). Inga postorbitalprocesser. Tårbenets öfre del bildar e'n utstande knö. Angularprocessen á underkïken är trubbig och föga utstaende. Kindtäuderna med ovala eller runda kronor, och deras rötter äro i början ofullständiga, derefter helt korta och föga delade. De öfe hafia en djup emaljbugt vid inre sidan, samt efter nötning 3 eller 4 emaljöar. Vid starkare nötning blir den inre bugten en ö, och då kronan är föga nött, förenar denna bugt sig med en yttre och delar tanden i 2 :ne lober. De undre likna de öfre, imen hafva bugten ingånde frin den yttre sidan. - Öfverläppen klufven. Fötterna med 5 tår, monen tummen å framfötterna rudimentär. De andra tårna ha starka klor. Öronen sma och nosen trubbig. Kroppen tjock, och ofvan och pa sidorne för det mesta tiickt af stora och långa taggar. - 4 arter från Europa, Asien och Afrika. Af dessa har $H$. cristata, Lin. de största näsbenen.

2. Underfun. Cavini, J. E. Gray.

Den öfre delen af tårbenen, med undantag af Coclogenys, stor och bredare än den öfre grenen af okbensutskottet. Kroppen hir- eller borstbetäckt.

\section{Slägtet Dasy procta, ILLIGER.}

Anm. Detta och följande slägte bilda en serskild grupp inom Cavini, utmärkte derigenom, att de hafva parallela kindtandrader, och tydliga postorbitalprocesser. Gray och Waterioose hafva uppställt denna grupp såsom en underfanilj under namn Dasyproctina.

1) Hos de olika arterua fürete näsbenen temligen stora skiljaktigheter uti sina dimensioner. 
Framfötterna med rulimentär tumme och 4 fullstänliga tár; bakfütterna med 3:ne tair, och klorna räta och nästan klöflika. Inga kindpaisar. Öronen temligen stora. Öfverläpen klufven. Svansen mycket kort. Kroppsformen smärt, och extreniteterna fina. Kroppen liarbetäckt, med längre hår baktil. - Kindtanderna med nästan fyrkantig krona med ett ingaiende emaljveck à biola eller endera sidan, samt med 4 eller 5 emalj-öar. Benhufvudet af langstrickt och nagot hoptryckt form, med nisbenen ungefir lika langa, som pambenen, och gaiende niogot lingre tillbaka än mellankiksbenen. Okbenen spensliga. Taubenens öfre del bred, och intagande nistan hela yttre sidan af den öfe grenen af olibensutskottet, sit att man blott ser en smal kant framtill af dema sednare. Underkïkens angularprocess spetsig och utdragen. - Omkring 8 arter frain S. Amerika, från Westindien till Paraguny. (D. aguti, (Lin.); kroppsl. 20").

\section{Slägtet Coelogenys, F. Cuvier.}

Fram- och bakfötter med 5 tîr. Kindpåsar förefinnas, som hafva sitt läge på inre sidan af kindbigarne, hvilka aro utomordentligen stora, och der urhalkade. Okbensutskotten ¿ öfrerkiken äro isynnerhet mycket stora, och deras starka utvidgning framtill har förorsakat en inskränkning af utrymmet för foramina infraorbitalia, som derigenom äro temligen små, och inåt och nedtill smalare. Tărbenens öfre del är liten och smalare än den öfre grenen af okbensutskotten. Kindtinderna likna dem af föregàende. Den bakre nuisöppningen lar a gommen en spetsig vinkel. Underkikens angularprocess är kort och afrundad. — Öronen små. Klorma trubbiga och klöflika. Svansen har endast form af en naken knöl. — Ett eller ett par arter från S. Amerika, från Cayenne till Paraguay. (C. paca (Lin.), kroppsl. 2').

\section{Sligtet Hydrochoerus, BrissoN.}

Den bakersta kindtanden i öferkäken längre än de 3:ne föregâende tillsammantagna, bestiende af omkring 12 transversella lameller, af hvilka den frïmsta har ett ingaiende veck vid yttre sidan. De andra öfre kindtänderna besta af 2 :ne lober, som inåt äro tillspetsade, och vid den yttre bredare sidan hafva ett ingaiende reck. Kindtänderna i underkäiken äro större än de frümsta ofvan, men ingen är så stor, som den bakersta ofvan. Kindtändernas rötter ofulstaindiga. Framtimlerna bäde $\mathrm{i}$ öfe och nedre käken hafva framtill en grumd fara. Benlufvudet, som ar nagot bredare än hos Dasyprocta, saknar postorbitalprocesser; okbenen äro korta, men starka. Processus paramastoidei serdeles langa och böjda. Näsbenen ungefir så långa, som pambenen. Kindtandraderna divergera bakåt. Underkäken har en mycket stor, hög och baktill trubbig angularprocess, en rudimentir coronö̈dprocess, en lag condylö̈rlprocess, och a ytre sidan af alveolardelen en utstáende köl. - Hufrudet stort. Öronen mycket små äfvensom ögonen. Framfötterna med 4 tår, och bakfötterna med 3:ne dito, alla till halfva lingden förenade genom simhud. Klurna klöflika. Sransen blott en hornartad knöl. Extremiteterna låga. Kroppen betäckt af temligen glesa, långa och strïfva hair. 1 art, H. capybara, Exxl., 4 ' ling. Förek. i S. Amerika frin Guyana till Rio de la Plata, ifven i Peru och Bolivia. Den störste af alla gnagare. 


\section{Slägtet Cavia, KLEIN.}

Svans saknas. Kindtinderna äro ungefür lika stora, hvarje med 2:ne lober, som äro åtskilde genom ett djupt, i öferkitken från inre, och i mulerkaken frân yttre sidan, inträngande emaljveck, och dessa lober hafva den frimre kanten konvex, och den bakre dito konkav eller jemn. i tändernas motsatta sida är ett grundare ingáende emaljveck. Kindtandraderna divergera starkt bakait. Benhufrudet saknar postorbitalprocesser, och taibenets öfre del är stor och bredare än okbensutskottets öfre gren. Gommen är baktill djupt utringad. Processus paramastoidei ïro korta. Underkäken liknar den af föreg., men angularprocessen är smalare. - Framfötterna med 4, och bakfötterna med tre tår, och klorna böjda och hoptryckta. - Omkr. 9 arter frin S. Amerika. (C. cobaya, Marcgr., eller det vanliga Marsvinet).

\section{Slägtet Cerod on, F. Cuvier.}

Skiljer sig endast frain föregaiende slägte derigenom, att kindtändernas lober hafva bâde främre och bakre kanten konvexa, och derigenom att klorna äro korta och breda. Benhufvudet är mera lingsträckt, och med längre nos. - Enligt GieBEL 5-6 arter, från S. Amerika. (C. rupestris, Pr. Maxim.), från Brasiliens bergstrakter).

\section{Slägtet Dolichotis, Desmarest.}

Kännes från de andra Cavinerna derigenom att den har långa, tillspetsade öron, ungefär likstora kindtändler, bakit starkt divergerande tandrader, samt en tydlig yttre, ehuru naken svans. Kindtanderna likna dem af Cerodon, med undantag deraf, att den bakersta $\mathrm{i}$ öfverkäken och den främsta i underkäken förete 3:ne lober. Benhufvudet liknar i det närmaste det af Cavia, men har nacken och nosen smalare, dik det betraktas ofvanifrin. Processus paramastoidei äro längre; gommen har baktill en ljupare intrüngande och spetsigare vinkel, som sträcker sig till början af den 3:dje kindtanden, och coronoüdprocessen i underkäken ä nagot tydligare. Pambenen hafva vid yttre kanten supraorbitalforamina, saisom en antydning till den incisur, som förefimnes framom postorbitalprocesserna hos hararne. Kindtandraderna divergera ännu mera. - De hafva mycken habituell likhet med hararne, och tyckas vara dessas ställföreträdare $\mathrm{i}$ de antaretiska delarne af $\mathrm{S}$. Amerika. De hafva smärta och temligen linga extremiteter, och de bakre äro betydligt lingre än de frümre. Dessa sednare hafva 4 och de bakre 3:ne tîr. Klorna trekantiga, och pai bakfötterna temligen langa. Metatarsen baktill pai den bakre halfelelen, och hälen nakna. - 1 art, D. putugonicu (Shaw), 21/2'lảng; frìn och med Patagonien till ungefär 37 sydl. breddgraden.

\section{2:dra Underordn. DUPLICIDENT A TI, ILLIGER.}

Fyra framtänder $\mathrm{i}$ öfverkäken; det ena paret bakom det andra. Af dessa äro endast det främre paret egentliga gnagtänter med persistent pulpa och skirande egg, och blott det 
bakre parets cylindriska och afhuggna tinder äro underkastade tandömsning. Foramina optica äro förenade, si̊ att man frản sidan kan der se tvïrtigenom septum mellan orbitæ.

'Till denna underordning höra endast 2:ne slägten, hvilka bilda hvartilera sin serskilda

familj. Man har hitintills brukat uppställa dem inom en och samma familj, Leporide, men de äro till sin byggnad sâ olika sinsemellan, att vi anse, att de böra betraktas sảsom typer för skilda familjer.

\section{Familjen LAGOMYID AE.}

Nyckelbenen fullstindiga, Benhufudet utan processus postorbitales, och med smal panna. Öronen korta och rundade. Kindtanderna $\frac{5-5}{5-5}$, med ofullständigar rötter; och, med undantag af den 1:sta ofvan och den 5:te nedan, med en transversell emaljrygg, som delar kronan i 2:ne fält, och hvilken är bildad af de bida emaljslyngor, som omsluta de bada tandlamellerna, och som hïr lägga sig intill hvarandra; och i hvardera sidan af tinderna ïr en ganska djup rertikal fära. Den 1:sta ofvan har en ingaiende bugt i framre kanten, och den 5:te nedan är enkel. Den 1:sta nedan har 2:ne ingảende bugter a hvardera sidan, samt är framât nigot tillspetsad. Craniet är nedtryckt. Os zygomaticum utsänder baktill en lảng process. Foramina infraorbitalia äro små, och dela icke öfrerkikeus okbensutskott. Nosen är smal, och har \& hvardera sidan nïra intill okbensutskottet ett stort hål, som är betäckt af en hinna. Yttre hörselöppningarne äro icke tubformade. Hjessan baktill med en crista sagittalis. Mellan nackbenet och hjessbenen är en crista lambdoidea, och det förra strächer sig' icke upp på öfre sidan af lijernkapseln, och interparietalbenet är tidigt försvinnande. Bullæe ossere stora, men processus paramastoidei otydliga. Foramina incisira merendels 2:ne par, af livilka det bakersta är stort; och gommen bildar en transversell brygga mellan tandraderna, som framtill begrinsas af dessa foramina, och baktill af bakre näsöppningen. Foramina carotico-jugularia aro serdeles stora. Underkäkens angularprocesser aro temligen utstaiende, baktill konvexa, samt med en kort uppait riktad trubbig spets. De äro icke så breda, som hos Lepus. Coronoüdprocessen bildar endast en liten afsats pa frimre kanten af den höga och stora condyloïdprocessen. Costa 17 par. Scapula bildad ungefir sísom hos Lepus. Clavicula spenslig, men fullständig. Underarmens ben synas icke vara hoploddade. Fibula är mera utbildad än hos Lepus, men nedtill sammansmilt med tibia. -- De bakre extremiteterna föga längre än de främre. Ingen yttre svans. Intestinum coecum med ett eller $2: n e$ bihang. Framfötterna med 5 och bakfötterna med 4 tảr. Smá kortbenta gnagare, som i sin kroppsform hafva mycken likhet med Marsvinen (Cavia). Blott ett slägte:

\section{Lagomys, G. Cuvier,}

hvars karakterer sammanfalla med familjens. - 9-11 arter från Europa, Asien och Norra Amerika, de flesta från Asien. (L. alpinus, Pall.) Kropps1. 8\%/". 
XIII. Familjen LEPORID Æ, J. Gray.

Nyckelbenen ofullstimdiga, varande rudimentära ossa clavicularia, som ligga lösa i köttet och hvarken äro fästade vid scapula eller sternum. Benhufvudet med processus postorbitales, som dock nảgon gaing sammansnälta med pannbenen; och pannan temligen bred. Öronen linga, mot spetsen något afsmalnande. Kindtïnderna $\frac{6-6}{55}$, med ofullständiga rötter, och hvarje tand bildad af 2 :ne af emalj omslutna transversella lameller, och gränsen mellan dessa i hvardera sidan antydd genom en grund ingiende bugt. Den bakersta kindtanden i öfverkikken är helt liten och enkel. Den främsta kindtanden i samma käke har â främre och imre sidorna 3:ne ingíende emaljveck. Den främsta kindtanden i underküken har den främre lamellen större samt försedd med en yttre sidofära. Benhufvudet är utmärkt genom en högre, nagot hoptryckt form; derigenom att nackbenet strïcker sig upp pi hjernkapselns öfre sida; att de yttre hörselöppningarne :iro tubformade; att bulla osseæe ïro af medelmåttig storlek och processus paramastoidei tydliga, men korta; att processus pterygoidei äro höga, och corpus ossis sphenoidei smal; att foramina incisiva äro enkla och mycket stora; att offerkäkens okbensutskott äro helt korta och odelade; att öfverkäkens sidor hafva ett af en hinna betäekt stort laâl, och för öfrigt äro i grannskapet af detta genombrutna eller retikulerade; att tirbenen äro starkt utstaende; att gombryggan är smal; att foramina carotico-jugularia äro mindre; att a underkäken den rudimentära coronoïdprocessen är temligen nïra condylus, och att angulardelen är afrundad och föga franstaende, och med en kant á báda sidor. Processtis postorbitales äro merendels stora, och utstiende sional framăt som bakát. Okbenen hafra en långsgaende grop a yttre sidan, och slutas baktill med en liten process. Interparietalbenet är mer eller mindre upphöjdt, liggande bakom hjessbenen, och tidigt sammanräxande med nackbenet. Underarmens ben äro sammanloddade. Fibula är liten och nedtill sammansmält med tibia. - Franfötterna med 5 och bakfütterna med 4 tår. Svansen kort, men tydlig och hairbevuxen. Äfven denna familj räknar blott ett sligte, med en temligen betydlig mängd arter, och af en ridstrickt geografisk utbredning.

\section{Slägtet Lepus, LinNé.}

Karaktererna de samma, som familjens. 35-40 arter från Europa, Asien, Atrika och N. och S. Amerika, frỉn de norra polartrakterna till ungefür 35:te sydliga breddgraden. (L. timidus, Lin.) 

- 




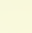




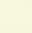





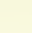





